\title{
LANDMINES: THE LOCAL EFFECTS OF DEMINING
}

\author{
MOUNU PREM ${ }^{\ddagger}$, MIGUEL E. PURROY*, AND JUAN F. VARGAS*
}

\begin{abstract}
Anti-personnel landmines thwart long-term development. However, mine removal may have no impact on socioeconomic outcomes if it fails to achieve full mine clearance. Using geolocated data on demining operations in Colombia and exploiting its staggered adoption, we show that humanitarian demining increases economic activity and academic achievement, especially where market access is superior. Instead, economic activity does not react to partial demining events that occur as a byproduct of ground military operations. Rather, this alternative demining treatment is more likely to exacerbate extractive activities.
\end{abstract}

Keywords: Landmines, demining, conflict, peace, local development.

JEL codes: D74, P48, Q56, I25.

Date: January 27, 2023.

We thank Campaña Colombiana Contra Minas (CCCM), Tatyana Deryugina, Pascaline Dupas, Francisco Eslava, Felipe González, Alvaro Jiménez, Rocco Macchiavello, Luis Martínez, Giovanni Mastrobuoni, Pablo Muñoz, Charu Prem, Julian Reif, Jonathan Roth, Sandra Sequeira, Manuela Vásquez, Pedro Sant'Anna, Santiago Saavedra, Austin Wright, UNMAS, and seminar participants at the 2021 Al Capone conference, 2021 LAMES, 2021 Red-BanRep Conference, 2022 ESOC Annual Conference, UCLA, LSE, Oxford, CEMFI, Einaudi Institute for Economics and Finance, Toulouse School of Economics, Paris School of Economics, Trinity College Dublin, Michigan State University, Collegio Carlo Alberto, Erasmus University Rotterdam, the Latin American Peace Science Society, Inter-American Development Bank, BanRep Medellín, and Universidad del Rosario for helpful comments and suggestions. We are especially grateful to the Oficina del Alto Comisionado para la Paz and CCCM for sharing the humanitarian demining data with us. Andrés Calderon, Felipe Coy, and Sergio Perilla provided excellent research assistance. We acknowledge funding from the Alianza EFI-Colombia Científica grant with code 60185 and contract number FP44842-220-2018. Prem acknowledges IAST funding from the French National Research Agency (ANR) under grant ANR-17-EURE-0010 (Investissements d'Avenir program).

${ }^{\ddagger}$ Einaudi Institute for Economics and Finance. Rome, Italy. email: francisco.munoz@eief.it.

*Harvard Kennedy School. Cambridge, US. email: mpurroy@hks.harvard.edu.

${ }^{\star}$ Department of Economics, Universidad del Rosario. Bogotá, Colombia. email:

juan.vargas@urosario.edu.co. 


\section{INTRODUCTION}

Landmines - explosives buried under the surface that trigger upon contact-are a pervasive weapon of war and hence one of the most pressing challenges to post-war recovery and longterm development. Together with unexploded ordnance, landmines threaten the lives and mobility of people, negatively affecting agricultural investment, access to markets and basic services, and schooling (UN General Assembly, 1996; CNMH, 2017). Since they are cheap to fabricate and their use is widespread in armed conflicts, landmines also constitute an obstacle to humanitarian aid and post-conflict reconstruction (Parker, 2018; Munroe et al., 2022). According to estimates, there are currently 110 million buried landmines worldwide, affecting around 60 countries. Ukraine, for example, has been greatly affected by landmine contamination, particularly following Russia's eastward fall back. ${ }^{1}$ Every year, landmine accidents result in the deaths and injuries of around 26,000 people (Hall, 2017), with 42\% of casualties being children. Since landmines are hard to detect and costly to remove, their damage extends well after the end of the war. ${ }^{2}$

The colossal current and expected costs associated with the presence and explosions of landmines imply that demining campaigns are one of the most pressing and potentially profitable post-conflict endeavors. However, and perhaps surprisingly, research on the socioeconomic effects of demining is relatively scarce and primarily relies on statistical associations. A recent notable exception is Chiovelli et al. (2019), who exploit municipal and annual variation to study the causal effect of humanitarian demining in Mozambique. ${ }^{3}$ The authors find that demining leads to an increase in nightlights, a proxy of local economic activity.

Using geo-referenced information for the case of Colombia, this paper both provides more detailed and fine-grained external validity to the Mozambican findings as well as causal micro evidence on the specific behavioral changes that demining generates upon affected communities that no longer face movement constraints. ${ }^{4}$ For instance, we show that by making

\footnotetext{
${ }^{1}$ The current landmine crisis in Ukraine has been reported, among others, by the United Nations Office for the Coordination of Humanitarian Affairs (OCHA) and by Human Rights Watch (see, e.g. https: //rb.gy/ujkcar and https://rb.gy/nklsel) (last accessed 28/11/2022).

${ }^{2}$ While building a landmine can cost between $\$ 3$ and $\$ 75$, removing it requires an investment of up to $\$ 1,000$ (Doswald-Beck et al., 1995). If landmine fabrication and planting would halt, it would take over a thousand years to strip the entire planet of landmines at the current demining rate.

${ }^{3}$ Humanitarian demining refers to the efforts of local and international non-governmental organizations (NGOs) to locate minefields and work with the support of affected communities to remove all the existing landmines until the area can confidently be called mine-free.

${ }^{4}$ The similarity with Chiovelli et al. (2019) in terms of the effect of demining on nightlights is quite reassuring for external validity. Colombia and Mozambique are indeed very different. According to the World Bank's Open Data (see https://data. worldbank. org -last accessed 09/14/21), Colombia's GDP per capita is over 11 times that of Mozambique; Mozambique's economy is much more dependent on agriculture (the share of agriculture value added over GDP is $26 \%$ versus $6 \%$ in Colombia); and Mozambique receives 3.5 times more official development assistance per capita than Colombia.
} 
cleared areas more attractive, demining increases population density. This is an alternative proxy of economic activity as higher density facilitates agglomeration economies (Acemoglu et al., 2002). Moreover, as humanitarian demining reduces the costs of school attendance and that of providing additional school inputs, it also increases enrollment and improves the performance of students across all school ages. As cohorts benefiting with additional access to (and quality of) education will likely be better off, our findings imply that humanitarian demining generates long-term benefits above and beyond the short-term increases in agricultural productivity.

In contrast, we also document that the removal of mines that occurs as a byproduct of ground military operations does not boost any economic or social outcome. ${ }^{5}$ As an additional contribution, we thus offer a much more nuanced view to the idea that demining unambiguously generates positive results.

Colombia is an interesting laboratory to study the economic and social effects of demining. Between 1999 and 2019, Colombia and Afghanistan alternated the record of the highest number of landmine casualties (Landmine Monitor, 2021). ${ }^{6}$ It also has the highest number of victims of improvised (handmade) mines, which are cheaper to fabricate but much more dangerous than industrial mines. Colombia has recently experienced different demining strategies, some of which had not previously been studied despite being quite common in internal armed conflicts throughout the world. Indeed, we examine the effects of both humanitarian mine clearance initiatives -which are common to many post-conflict environments-and demining episodes that take place in the context of military anti-insurgency operations, advancement, or maneuvers. While the former largely involves affected communities (including the delivery of mine-risk education programs) and ensures that affected areas are completely stripped from landmines, the latter has neither feature.

Our identification strategy exploits the exact coordinates of all demining events and relies on the timing of demining campaigns that took place after the start of peace negotiations with the Revolutionary Armed Forces of Colombia (FARC from its Spanish acronym). Specifically, we compare the evolution of various outcomes of interest - many of which help us understand the documented reduced-form relationship between demining and economic growth-in areas subject to demining with those in Confirmed Hazardous Areas that had yet-to-be or were never demined during our sample period (see section 2). Because our data on demining is

\footnotetext{
${ }^{5}$ This alternative demining "treatment," which is neither aimed at relieving entire mined areas nor at helping affected communities, is not present in the Mozambican case. While in this country, the end of the civil war in 1992 largely ended hostilities, in Colombia, the 2016 peace agreement excluded several active armed groups with national presence (Prem et al., 2022). Therefore, humanitarian demining there has occurred simultaneously with persistent military operations of the Colombian armed forces.

${ }^{6}$ In 2020, Syria became the country with the highest number of victims.
} 
geo-referenced, we focus on highly disaggregated local effects within a $5 \mathrm{Km}$ radius in the baseline results.

Our estimation of the causal effects of demining takes into account the recently documented problems of using two-way fixed effects to estimate causal effects in difference-in-differences settings with staggered adoption and heterogeneous treatment effects. First, we assess how relevant this is for our context by computing the decomposition suggested by GoodmanBacon (2021), and we find evidence against using standard linear techniques. Second, our baseline specification uses the estimator proposed by Callaway and Sant'Anna (2021) that is based on a parallel trends assumption, and computes group-time average treatment effects (ATTs) that are later aggregated to compute an overall ATT. Third, we explore the robustness of our results to using alternative estimators, such as those proposed by Borusyak et al. (2021), De Chaisemartin and d'Haultfoeuille (2020), and Wooldridge (2021). Fourth, to assess the validity of our main identifying assumption (namely, that the post-treatment potential outcomes of treated cohorts have the same trend as those of the never treated and the soon-to-be-treated cohorts), we report the dynamics of the estimator, as well as corrections for potential bias coming from pre-treatment differential trends (Roth, 2022), and the robustness of our results to moderate linear and non-linear violations of the parallel trends assumption (Rambachan and Roth, 2021). Fifth, we show the robustness of our results to: i) adding municipality-specific time trends, as well as pre-treatment municipality and event-level covariates in a doubly-robust fashion as suggested by Sant'Anna and Zhao (2020); ii) using different radii around the demining event; iii) using different comparison units and periods; iv) accounting for potential spatial spillovers coming from the fact that current demining is likely to take place in the vicinity of past demining; and v) winsorizing outliers in our dependent variables.

The economic and social effects of demining are manifest in a wide set of outcomes. Because the presence of landmines hinders rural investment, market access, and mobility, we first look at whether demining affects economic activity and other social interactions likely to result in nighttime light density and population density changes. Second, we look at the effect of demining on students' performance. The relevance of studying both economic activity and learning outcomes is manifest in the observation that, according to our database, a large share of landmines are planted on or near rural roads or in the vicinity of schools. Third, because demining lowers the entry barriers of both productive and extractive rural investments, it may also increase deforestation. We thus also explore the effect of demining on forest loss. Fourth, in the Colombian context, the new rural investors that demining attracts may be associated with the illegal groups that persisted after the peace process (see section 
2). Therefore, we also study how demining affects alluvial illegal gold mining, and illicit extractive activities such as coca crops. ${ }^{7}$ Moreover, the latter may trigger further deforestation pressures. This last set of outcomes may also respond to the dynamics of demining inasmuch as illegal groups often protect their strongholds and illicit crops with mine fields (Fundación Seguridad y Democracia, 2006; CNMH, 2017).

We find that humanitarian demining campaigns led to improvements in socioeconomic conditions. In particular, we find a $12.4 \%$ increase in nighttime luminosity and a $2.7 \%$ increase in population density. A back-of-the-envelope calculation based on Henderson et al. (2011) yields that each humanitarian demining event increases the municipal GDP by $0.8 \%$, and each dollar invested in humanitarian demining yields $\$ 7$ in benefits after only one year. We also find a 6.7 (8.1) percentage points increase in the probability that students obtain at least a satisfactory score in standardized national tests in math (reading). Students' performance in national standardized exams improves as soon as demining occurs and persists thereafter. We argue that this immediate effect is related to mechanisms on both school composition and students' performance. On the one hand, humanitarian demining attracts new migrants to the cleared region, which increases school enrollment. This likely generates a positive selection of new students from better-off households who had fled away from violence (Chiovelli et al., 2021). On the other, demining increases the share of students promoted to the next grade and generates a net reduction in the students-to-teachers-ratio. Our estimates suggest that the composition channel can explain up to $49 \%$ of the effect of demining on students' academic performance.

To shed some light on the potential mechanisms of the effects of humanitarian demining on economic activity and students' academic achievement, we show that such positive effects are larger in areas that are better connected to labor, inputs, and output markets through the available road network. Indeed, connectivity is key to reap the economic potential that follows mine clearance campaigns. Moreover, it facilitates school attendance and reduces absenteeism. We also complement the reduced-form analysis of the importance of road connectivity with a market access general equilibrium framework $\grave{a}$ la Donaldson and Hornbeck (2016), which allows us to compute economy-wide effects. We find that in the absence of humanitarian demining efforts, Colombia would have forgone 0.7 percent of its annual GDP between 2013 and 2019. This figure is very similar to the reduced-form computations.

In contrast with the case of humanitarian demining, demining as a byproduct of military operations, which did not have the objective of achieving the complete clearance of targeted areas, had no statistically significant effects neither on nighttime luminosity nor on students'

${ }^{7}$ Coca leaves are the main input of cocaine, of which Colombia is the main exporter worldwide, including about $90 \%$ of the U.S. market. 
performance. Instead, it decreased population density. This is likely a byproduct of the effect of such type of demining on land extractive activities, which we summarize next.

Since stripping the land from the threat of explosives is likely to summon new rural investment (some of which may result in forest loss), we also study the effects of demining on deforestation. We find that while humanitarian demining had no significant effects on deforestation, demining events resulting from military operations caused large increases in deforestation. Relatedly, we document a differential increase in the use of wildfire, which by and large is associated with extractive agricultural activities, as well as an increase in illegal gold mining. We look at spatially disaggregated data on soil suitability to shed light on the potential mechanisms underlying this finding. We find that the deforestation surge after military demining is more pronounced in areas suitable for extractive agricultural activities such as oil palm, cattle ranching, rubber planting, and forestry. We interpret these findings as consistent with the idea that demining in military operations serves the interest of elites with stakes in extractive economies.

Finally, we find that both humanitarian demining and demining episodes that occur in the context of military operations decreased coca cultivation and hence the potential production of cocaine. We also exploit the implementation of an illegal-crops substitution program that was implemented after the signature of the peace agreement with FARC to estimate heterogeneous effects parametrized by the program's presence. We find that the demining-led decrease in coca cultivation is driven by municipalities where the crop substitution program was implemented. This implies that the coexistence and mutual reinforcement of different policies (and illegal-crops substitution) can effectively reduce illegal drug production. This is particularly relevant given the failure of the War on Drugs in producing countries. ${ }^{8}$

In short, we find that the local effects of demining largely depend on the type of mine removal strategy. When demining is carried out by domestic and international NGOs to protect affected communities and clear entire areas from landmines, this increases productive economic activities, population density, and the quality of education as measured by students' test performance. Instead, if demining takes place in the context of military activity, which does not result in mine-free zones, then it exacerbates deforestation and extractive activities. We show that these differences are not entirely driven neither by the fact that humanitarian and military demining target different areas, nor by the fact that humanitarian demining typically results in a larger number of landmines extracted or deactivated. This implies that the differences most likely come from the different nature of the two types of demining, with humanitarian demining being a process that both involve the local community and ensures that areas are completely cleared from landmines. Still, we argue that these

\footnotetext{
${ }^{8}$ See Prem et al. (2021a) for a thorough review and a recent example for the Colombian case.
} 
differences should be taken with caution, given that the two treatments are fundamentally different in nature and cannot be thought of as alternative policy instruments aimed at the same objective.

Our paper contributes to the recent evidence on the economic effects of demining, championed by Chiovelli et al. (2019). We do so in two key dimensions. First, using a detailed geo-located variation, we offer a comprehensive analysis of the effects of demining on various socio-economic aspects, including - but not limited to - nighttime lights. For instance, studying the effect of demining on educational outcomes allows us to better understand the potential long-term socio-economic consequences of landmines' removal, that cannot be accounted for by nighttime lights. Looking at population density helps us gauge the potential effects of demining on internal migration patterns. We also explore a variety of outcomes that provide evidence of the effects of mines' clearance on desirable and adverse land-use dynamics. Second, we study different types of demining processes that differ in the extent of community involvement and how comprehensive the landmine clearance is. This allows us to put in perspective the idea that demining is unquestionably good.

Our paper also contributes to the literature that studies the long-term economic effects of the massive U.S.-led aerial bombing campaigns that took place during the wars in Cambodia and Laos (Lin, 2020; Riaño and Valencia Caicedo, 2020). We posit that the long-term negative effects of buried aerial UXO documented in these contexts are likely only a fraction of those that come from mines that are cheaper to fabricate and intentionally hidden underground instead of accidentally unexploded. In fact, landmine contamination is still a problem in around 60 countries, while unexploded aerial bombs are currently prevalent only in those two countries, as well as Ukraine. ${ }^{9}$ Finally, we also contribute to the literature studying the effects of landmine contamination on voting behavior (Vargas et al., 2022), health (Arcand et al., 2015), education (Merrouche, 2011), and poverty (Merrouche, 2008).

\section{Context}

2.1 Colombia's civil war and the peace process The start of Colombia's internal armed conflict dates back to the 1960s, when FARC and the National Liberation Army (ELN from its Spanish acronym) were founded. The other main set of illegal actors in the Colombian conflict are right-wing paramilitary groups, originally armed by the state in the early 1970s and trained as self-defense organizations. Much more than other armed groups, guerrillas have extensively used landmines as a way to secure their strongholds as well as their control over areas that host illegal crops.

\footnotetext{
${ }^{9}$ In contrast, largely due to post-war investments, aerial bombings in Vietnam had no negative long-term effects (Miguel and Roland, 2011; Dell and Querubin, 2018).
} 
In October 2012, the Colombian government and FARC started peace negotiations in Cuba. FARC's offensive activity quickly dropped by $98 \%$ (CERAC, 2016) and humanitarian demining efforts picked up. As a result, victims from anti-personnel landmines plummeted in FARC-affected municipalities (Perilla et al., 2022). In Appendix Figure B1, we document a large drop in the incidence of various conflict-related outcomes since the beginning of the peace negotiations.

2.2 Landmines in Colombia Colombia is the country with the highest number of victims of improvised anti-personnel mines, homemade explosives that detonate by contact or even in the proximity of a person or object. They are harder to detect and remove without risking an explosion (Landmine Monitor, 2019). While the use of landmines in the conflict dates to the 1980s by all illegal armed actors, the main milestone in the fabrication and planting of improvised mines in Colombia came in 2008, when FARC's secretariat launched a strategy that they called Plan Renacer Revolucionario de las Masas (Revolutionary Rebirth of the Masses). In an internal secret memorandum, commander 'Alfonso Cano' instigated all fronts to strengthen their ongoing production and planting of landmines in order to protect their strongholds (see Appendix Figure B2 for a picture of the memo in the original Spanish). By 2017, the area contaminated with landmines was officially estimated to be around 11,400 acres (Landmine Monitor, 2017), which is equivalent to almost $80 \%$ of the size of Manhattan.

As a signatory of the 1997 Ottawa Convention, Colombia adopted in 2002 the Information Management System for Mine Action (IMSMA) of the Geneva International Centre for Humanitarian Demining (GICHD), a registry of landmine explosions, suspicion of presence, and demining events. It also committed to clear all landmines from its territory by 2021 (which by now has been extended to 2025). However, due to the intensity and territorial reach of the ongoing conflict, large-scale humanitarian demining and full clearance operations did not pick up until after the start of peace negotiations with FARC.

\subsection{Humanitarian mine clearance versus demining in military operations $\mathrm{Hu}-$} manitarian demining is the assistance specialized NGOs provide to communities exposed to the contamination of explosive devices (anti-personnel landmines and UXO, PAICMA, 2012). In Colombia, this takes place since 2013, when the peace negotiation with FARC was underway. Five international and two national NGOs have been accredited to engage in humanitarian demining by the Inter-institutional Instance of Humanitarian Demining (IIDH from its Spanish acronym), a joint body composed by the Ministry of Defense, the General Inspection of the Military Forces, and the Office of the High Commissioner for Peace (OACP from its Spanish acronym-Decree 3750 of 2011). ${ }^{10}$ The certified organizations must comply

\footnotetext{
${ }^{10}$ The first NGO that engaged in demining activity was the British NGO Halo Trust in 2013. In fact, since the start of peace negotiations, the parties agreed to allow the establishment of humanitarian demining campaigns, and in the final peace agreement, the involvement in demining activities was highlighted as a
} 
with the National Standards of the Integral Action against Anti-Personal Mines, a set of standards issued by the IIDH to regulate all strategic and operative humanitarian demining activities. The authority checks compliance periodically and (re-)certifies the NGOs every year. This allows them to continue their operation. ${ }^{11}$

The prioritization of areas targeted for humanitarian demining is done by the IIDH. To that end, the IIDH uses the pool of Confirmed Hazardous Areas, where the presence of landmines has been confirmed by a technical team of the OACP through a technical examination of a Potential Hazardous Area (PTA). In turn, PTA are areas where the presence of landmines is suspected, either because of reports issued by local communities or because of a recorded landmine accident. Within such areas, prioritization is solely based on the number of recent landmine accidents (and casualties). ${ }^{12}$ We corroborate this in Figure 1, where by and large the only pre-treatment characteristic that is correlated with both the timing of humanitarian demining (Panel A) and its intensity (in terms of the size of the targeted area, Panel B) is past landmine victimization. ${ }^{13}$ Other key variables, including most of the lagged value and first difference of our main outcomes, are not correlated with the timing or the intensity of the treatment. ${ }^{14}$ Importantly, however, in our regressions, we control flexibly for this selection variable, and our results are unaffected.

After an area has been prioritized for demining, OACP launches a call, and the accredited NGOs have to bid for the right of demining it. To that end, the NGOs submit a proposal that must meet the aforementioned technical standards and proof sufficient funding. Proposals are then reviewed by the IIDH, which decides upon the allocation of the prioritized area. ${ }^{15}$ In the allocated areas, the winning NGO must engage in three main activities. First, it approaches the community and finds at least one local liaison who helps build links within the community. The objective is to better understand the context, and convey the NGO's principles of neutrality and impartiality to the broader community, in order to gain their trust and cooperation. Second, the NGO conducts community-level surveys to determine if there are Hazardous Areas (HA), suspected to be mined. Third, a technical team visits all HA to confirm the existence of landmines or UXO from a safe distance, using metal detectors and sound beams. If the HA is dismissed, then it is certified as mine-free. If it is confirmed,

key activity for the reincorporation of former FARC combatants (see excerpts 3.2.2.6-part b, 4.1.3.1, and 6.2.3-part of the text of the agreement).

11 The legal standards (in the original Spanish) can be obtained from: http://www.accioncontraminas . gov.co/Estandares (last accessed 12/13/2022).

${ }^{12}$ For a detailed discussion, see https://rb.gy/vsv3be (last accessed 12/13/2022).

${ }^{13}$ The only exception is the change in math test scores, which is marginally significant in Panel A.

${ }^{14}$ The covariates are measured as the average of their values over the period 2010-2012.

${ }^{15}$ Because all demining operators have to follow the same standards and are also monitored by the same actors (especially the Organization of American States) the bidding process has no effect in the quality of the demining operation, and thus on its impacts. 
the technical team removes the existing mines or engages in controlled blasts until the area is declared clear. Demining NGOs also provide assistance to mine victims, as well as pedagogical seminars aimed at raising awareness and promoting safe behavior. ${ }^{16}$ Because of the comprehensiveness of the process and the engagement of the community, the average time that the full clearance of an area takes with humanitarian demining is 16 months. ${ }^{17}$

Importantly, while the government (through the IIDH) has a key role in the selection of prioritized areas, the allocation of demining tasks across NGOs and the coordination of all demining actions across the national territory, it does very little in the aftermath of humanitarian demining to help affected communities. Indeed, the operators often complain that the lack of institutional building and local development initiatives constitute a threat to the long-term sustainability of the demining process (see, e.g., Mutual-Co, 2021). This suggests that post-demining public development investments are an unlikely mechanism behind our effects. Moreover, we document that humanitarian demining has not been accompanied by a differential increase in foreign aid from international cooperation. ${ }^{18}$ Appendix Table B2 shows that neither the yearly flow of resources from the international cooperation (Columns 1 and 2) nor the stock of foreign aid packages committed on a given year (Columns 3 and 4) react to the humanitarian mine clearance. ${ }^{19}$

In contrast, demining activities amid military operations have long existed as part of the dynamics of internal conflict. The military constantly engages in mine removal and controlled explosions as part of their anti-insurgency operations and maneuvers, and as a way to clear paths for the advancement of troops and warfare equipment. Key to facilitating ground mobilization, military operations often include personnel from specialized anti-explosives groups, in charge of the detection and destruction of antipersonnel mines and UXO. But these activities are not linked to the government's Integral Action against Antipersonnel Mines, they do not involve local communities and their objective is not to declare entire areas as cleared from mines.

Humanitarian and military demining are therefore fundamentally different "treatments." While in the former, the clearance of an entire mined area is the main objective, in the second, demining is an intermediate objective to achieve a strategic goal other than demining per se, and thus it is seldom comprehensive within demined areas and it is disassociated from

\footnotetext{
${ }^{16}$ Qualitative evidence suggests that humanitarian demining improves the perception of safety and the willingness to undertake productive activities in the land. Mine clearance also seems to have increased the value of land and attracted tourism (Mutual-Co, 2021).

${ }^{17}$ Own calculations using the data described in section 3.

${ }^{18}$ This is important because foreign aid is the main source of funding for Colombia's rural development programs and for the implementation of the peace agreement (Casanova Ramírez et al., 2017; APC, 2020; García Duque and Casadiego, 2021; Osorio, 2022).

${ }^{19}$ In fact, the point estimates are very small (up to 2.5 percent of the mean) and not statistically significant.
} 
wider community empowerment efforts. This implies that the results from looking at one or the other are not directly comparable. However, in our empirical analysis, we do include, for robustness, additional exercises that attempt to make the comparison somewhat fairer by focusing on areas potentially affected by both humanitarian mine clearance and demining in military operations and by focusing on demining events of similar intensity.

\section{DATA}

3.1 Demining The IMSMA information system (see section 2) provides detailed georeferenced data on all landmine demining events (both humanitarian and resulting from military ground operations), as well as on the confirmed or suspected presence of antipersonnel mines from 2003 onward. The database includes the exact location of all demining events and the year of occurrence. As of March 31 of 2021, the database included 24,746 demining events in military operations, all geo-located with accurate military GPS technology. ${ }^{20}$ It also reordered 2,272 hazardous areas. Of these, 1,141 had been confirmed to host landmines and 645 had been cleared by the seven active NGOs in charge of humanitarian demining. ${ }^{21}$

From these data, we code two treatments: i) humanitarian demining and ii) demining as a byproduct of military operations. We focus on the sample period 2013-2019 because prior to then, there was no humanitarian demining in Colombia. In turn, as discussed in section 2, in 2013, peace negotiations with FARC well already underway, which precipitated the decision of the Colombian government to undertake humanitarian demining in order to comply with the Ottawa Convention. Moreover, key for identification, we remove 2020 and 2021 from our sample period to code our "never-treated" comparison group with the information of those two years.

3.2 Outcomes Since we focus on the local effects of demining (on areas located within a short radius from the demining event), our main set of outcomes is composed of variables that can either be geo-referenced or are available for relatively small spatial grids. This subsection describes such outcomes and discusses their measurement and sources.

3.2.1 Nighttime lights Nighttime light has been shown to be a reliable proxy for economic activity both nationally and in geographically small areas (Henderson et al., 2011; Michalopoulos and Papaioannou, 2013; Storeygard, 2016; Martinez, 2021). It also may capture other types of human activities that result in higher electricity usage. We use the global

\footnotetext{
${ }^{20}$ Camp et al. (2016) show that in Ecuadorean Andes (a topography very similar to Colombia's) the location error of the GPS information is 9.6 meters (with a standard deviation of 4.7 meters). Given the baseline radius that we use to estimate the effects of demining $(5 \mathrm{Km})$, a location error of such magnitude should not be a major concern.

${ }^{21}$ The information on humanitarian demining provided by IMSMA coincides very accurately with that of the administrative records of the NGOs.
} 
harmonized nighttime light (NTL) dataset constructed by Li et al. (2020), which addresses all the known problems of nighttime lights, such as intercalibration, geometric correction, and blurring. Nightlight images are available for grids of $1 \mathrm{Km}^{2}$, so for our outcome of interest, we take all the pixels that intersect the buffer of a demining event and compute a weighted average of their luminosity value. ${ }^{22}$

Appendix Figure A1 corroborates that this measure is highly correlated with various socioeconomic outcomes at the municipality level. These include value-added, mortality rate under five years old, an index for fiscal performance, literacy rate, and a poverty index. This correlation is high both for the entire country and for the relatively more rural municipalities, which host the vast majority of landmines and thus where most demining takes place.

3.2.2 Population density Population density is an alternative proxy of economic activity that has been widely used by economic historians. For instance, Acemoglu et al. (2002) argue that only prosperous areas can support dense populations, and that population density contributes to economic growth by encouraging the exchange of ideas. We, therefore, compute a buffer-specific population density measure. To that end, we use the $1 \mathrm{Km}^{2}$ population rasters provided by WorldPop and the Center for International Earth Science Information Network (CIESIN). ${ }^{23}$ We then compute the average of the estimated population density within each buffer of our sample.

3.2.3 Schools and the performance of students in test scores To assess the impact of demining on students' performance in standardized test scores, we start by constructing a novel geo-referenced database of all schools in Colombia. ${ }^{24}$ We then merge to these data the average academic achievement of all the school students in the reading and math standardized national tests (called "Saber"), that are implemented yearly in selected grades (3rd, 5th, and 9 th). ${ }^{25}$

\footnotetext{
${ }^{22}$ The weights are given by the product of the luminosity value of each intersecting lit pixel and the fraction of the buffer area that overlays with that pixel. To deal with outliers and with observations with zero average light, we use the hyperbolic sine transformation of the average luminosity within the buffer.

${ }^{23}$ The data can be downloaded from https://www.worldpop.org/geodata/listing?id=76. The population raster is estimated by the source following the methodology proposed by Stevens et al. (2015), which uses the disaggregated 2005 census data and a Random Forest machine learning model that includes remotelysensed data and geographic administrative data to predict grid-level population values. The model uses cross-sectional as well as time-varying variables for the prediction, including various types of land use, nighttime lights, and climate and geographic characteristics, and the presence of local facilities.

${ }^{24}$ We did so by web-scraping the school information from the Education System of Educational Sites (SISE): https://geoportal.dane.gov.co/SISE/sise/. This is a cross-section database, but the change of school locations is very rare, especially in the more rural areas where demining takes place (Gómez Montoya et al., 2018).

${ }^{25}$ This information comes from administrative datasets of the Colombian Institute for the Evaluation of Education (ICFES from its Spanish acronym) and is available for the period 2012-2018 in the form of schoollevel averages. We do not include test scores from the end-of-high-school national test ("Saber 11"), as
} 
We construct our measure of buffer-level students' probability of obtaining at least a satisfactory score in the standardized test (which for simplicity we call students' performance) by computing the weighted average of the fraction of students enrolled in schools within the buffer that passed the test. The weight is the number of students that took the test in each school/year. Interestingly, we find that $96 \%$ (77\%) of the buffers around a humanitarian (military) demining event have at least one school. Moreover, on average, nine schools fall within each (5 Km radius) buffer in our estimation sample.

3.2.4 Extractive activity We also measure buffer-specific yearly forest loss using the satellitebased estimates of the Global Forest Change (GFC) project, which includes information on changes in tree coverage with a resolution of approximately $30 \mathrm{~m}^{2}$, estimated from Landsat images (Hansen et al., 2013). Deforestation is identified by GFC when a specific pixel changes its tree cover status from one year to the other. For each buffer of our sample, we compute the area occupied by pixels that became deforested in a specific year and use the hyperbolic sine transformation of this variable.

With the increasing use of fire as a deforestation tool, most of which is illegal, we explore the robustness of our deforestation results by using the data from NASA's Fire Information for Resource Management System (FIRMS). With this input, we compute the total number of fires that take place each year within each buffer.

We also have geo-referenced data on the existence and the geographic extension of illegal alluvial gold mining (EVOA from its Spanish acronym). This information is available in $1 \mathrm{Km}^{2}$ grids for the years 2014, 2016, 2018, and 2019, and is estimated by the United Nations Office on Drugs and Crime (UNODC) using remote sensing methods. The illegality of the mines can be inferred after overlaying the EVOA raster with official geo-referenced data on mine titles. ${ }^{26}$

3.2.5 Coca cultivation To measure the size of illicit coca crops, the leaves of which are mixed with chemicals to produce cocaine and crack, we rely on the satellite-based annual estimation performed by the Integrated Monitoring System of Illicit Crops (SIMCI from its Spanish acronym) of UNODC. SIMCI uses satellite imagery to estimate coca production by the end of each calendar year with remote sensing tools, which are validated with highdefinition photographs taken from a helicopter. ${ }^{27}$ The data is produced in grids of $1 \mathrm{Km}^{2}$

these are not comparable across years during our sample period, due to several methodological changes documented in ICFES (2019).

${ }^{26}$ Moreover, UNODC cross-checks the estimates with local environmental NGOs that often corroborate the existence of an alluvial gold mine. In 2019, 66\% of the detected EVOA area corresponds to illegal exploitation, $27 \%$ corresponds to legal (titled) exploitation, and the remaining $7 \%$ are mines in the process of being legalized UNODC (2020).

${ }^{27}$ SIMCI uses satellite images for a wide window around December 31st. In particular, about 70 percent of the images are obtained between mid-November of the year of the estimate and late February of the following 
from 1999 to 2019. This allows us to compute the buffer-specific area covered with coca crops. Our dependent variable is the hyperbolic sine transformation of this measure.

The description of additional variables and data sources, as well as the descriptive statistics, are reported in section A of the Appendix.

\section{Empirichl Strategy}

4.1 Staggered Difference-in-Differences To study the local effects of demining before and after the end of the conflict with FARC, we exploit both the timing of demining events as well as their exact geo-referenced location. Our unit of analysis is the $5 \mathrm{Km}$-radius circle around the geographic location of the event. ${ }^{28}$ Because demining activity takes place at different times along our sample period, we could estimate a staggered difference-indifferences specification of the form:

$$
y_{i t}=\alpha_{i}+\lambda_{t}+\beta \times \text { Post }_{i t}+\varepsilon_{i t},
$$

where $y_{i t}$ are different measures of local activity measured within buffer $i$ and in time $t$. Post $_{i t}$ is a dummy that takes the value one in buffer $i$ after a demining event and zero otherwise. $\alpha_{i}$ are event/buffer-level fixed effects and $\lambda_{t}$ are year fixed effects.

A recent literature had documented that this type of two-way fixed effects (TWFE) model can suffer from a severe bias, which makes the estimated coefficient of interest $(\beta)$ different from the true average treatment effect on the treated (ATT). This is likely to occur when treatment effects are heterogeneous over time and across units. To assess the extent to which this is the case in our context, we start by performing the decomposition suggested by Goodman-Bacon (2021). We report the results in Appendix Table A1, and find that in the case of humanitarian demining, $5 \%$ of the TWFE estimate comes from the "forbidden comparison" (that uses the early treated units as controls for units treated later), while this is $27 \%$ for the case of military demining. In turn, these figures are consistent with the fact that the share of never-treated units is relatively low, especially in the case of military demining events. ${ }^{29}$ This implies that using TWFE in our context would most likely lead to biased estimates.

year. Of the remaining 30 percent, roughly half is obtained from August to November of the year of the estimate, and the residual is obtained between March and April of the following year.

${ }^{28}$ In the Appendix, we show the robustness of our results to different radii, specifically $3,4,6$, and $7 \mathrm{~km}$ around the location of the demining event.

${ }^{29}$ Since the estimated $\beta$ is a weighted average of event-specific ATTs, we follow De Chaisemartin and d'Haultfoeuille (2020) to compute the share of ATTs that enter the computation with a negative weight. Consistent with Goodman-Bacon (2021)'s decomposition, we find that the share of negative weights is zero for humanitarian demining and $27 \%$ for demining in military operations. 
Given the results of these diagnostics, we follow the recent developments regarding the estimation of these types of models. In particular, we follow the Callaway and Sant'Anna (2021)'s procedure, which estimates group-time $(g, t)$-specific ATTs avoiding incorrect comparisons. These are then aggregated in ways that allow the presentation of both "eventstudy" figures and average estimates using a range of potential weighting functions. ${ }^{30} \mathrm{Im}$ portantly, in section B of the Appendix, we corroborate that our results are robust to using alternative estimation methods, that also address the potential problems of the TWFE model, including those suggested by Borusyak et al. (2021), De Chaisemartin and d'Haultfoeuille (2020), and Wooldridge (2021). ${ }^{31}$

One key feature of these types of models is the inclusion of a set of "never-treated" units, that however, could have been treated. To this end, we need to identify mined areas that were not demined during our sample period, but that could have been so. For the case of military demining, we use as never treated the demining events that occurred in 2020 and 2021, after the end of our sample period. For the case of humanitarian demining, we use as never treated both the 2020-2021 demining as well as the areas confirmed to have mines but not yet demined due to the limited capacity of humanitarian demining NGOs.

Appendix Figure A2 reports, for each demining type, the number of treated units by year together with the never treated. It can be concluded that, while the number of never-treated units used for the analysis of humanitarian demining is fairly large, that available for postconflict military demining is relatively small. ${ }^{32}$ This suggests that using the "not-yet-treated" units as a complementary comparison group is important in our context. ${ }^{33}$

Finally, as suggested by Callaway and Sant'Anna (2021), we balance our estimation period around the event data, to avoid the estimates being confounded by changes in the weights driven by sample composition. Specifically, we use three years before and three years after the demining event.

4.1.1 Identifying assumption The main identifying assumption for the "not-yet-treated" version of the Callaway and Sant'Anna (2021) estimator is that the evolution in potential outcomes after the treatment is the same for treated cohorts $g$ and never-treated (and/or soon-to-be-treated) units. We present the dynamic treatment effect version of the authors'

\footnotetext{
${ }^{30}$ We use the "simple" aggregation (as recommended by the authors) that uses as weight the size of the group-year cell. However, we also present the group-level aggregation in Appendix Table A2, which first computes the ATT for each cohort $g$ and then takes the average across them.

${ }^{31}$ Even though the estimation methods differ across papers, they all rely on some version of a parallel trends assumption for identification.

${ }^{32}$ While it is impossible to know with the data at hand, it may also be the case that the never treated units were not mined at the start of the sample period.

${ }^{33}$ In the Appendix, we show that results are similar if we estimate the baseline model using only either the "never-treated" or the "not-yet-treated" units as controls.
} 
estimator in order to partially assess the validity of this assumption (Marcus and Sant'Anna, 2021). We also present the corrections for pre-testing bias and bias from a pre-demining linear trend following Roth (2022), as well as for the robustness of our results to moderate linear and non-linear deviations from the parallel trend assumption following Rambachan and Roth (2021).

\section{MAin RESUlTS}

This section discusses our estimated results. We start by summarizing our findings regarding the impact of humanitarian demining efforts and then turn to that of demining in military operations. We then assess the validity of the main identifying assumption of our empirical strategy and summarize a battery of robustness tests that we report in Appendix section B.

5.1 Humanitarian demining Table 1 reports the main results concerning the effects of the humanitarian demining efforts that started after the end of the conflict. We do so in terms of six substantive outcomes, which are likely affected by demining given the obstacles that landmines pose on mobility and agricultural investments, and the strategic use of landmines to protect illicit economies. The main outcomes are: nighttime lights (Column 1) and population density (Column 2), which are proxies of economic activity; the probability that students obtain a satisfactory grade in math (Column 3) and reading (Column 4) standardized national test scores; forest loss (Column 5) and the size of coca crops (Column 6).

Recall that we estimate the causal effect of both demining treatments using Callaway and Sant'Anna (2021)'s procedure, and report group-time aggregate ATTs together with their respective standard errors, clustered at the event (buffer) level. ${ }^{34}$ We also present p-values that control for the family-wise error rate in multiple hypotheses testing following Romano and Wolf (2005). Table 1 reports the baseline results estimated for buffers of $5 \mathrm{Km}$ radius around the geo-located event, and for a three-year window around the event date.

The table includes four panels with the objective of exploring the robustness of the estimated impact of humanitarian demining. Panel A is the baseline specification with no controls. Panel B adds buffer-level geographic covariates in a doubly robust way, following Sant'Anna and Zhao (2020). This procedure allows the specification to be robust to either the misspecification of the kernel-based difference-in-differences estimator that includes covariates in a flexible way (Heckman et al., 1997), or misspecification of the inverse probability weighted

\footnotetext{
${ }^{34}$ Appendix Table A3 reports the robustness to using two alternative clustering levels, one at the level of submunicipal hamlets (called "vereda") and the other one at the level of $15 x 15 \mathrm{~km}$ grids. Aside from somewhat more imprecise estimates for the effect of post-conflict demining on population density, the results are very similar. Note that, unfortunately, no Conley-type standard errors that account for spatial correlation have been developed for these types of models. However, in an additional robustness test, we follow Bauman et al. (2018) and include the Moran eigenvectors as covariates to remove the spatial autocorrelation from the residuals. The results are reported in Appendix Table A4.
} 
estimator (Abadie, 2005). ${ }^{35}$ Also following the doubly-robust procedure, Panel C includes municipal-level covariates, one of them being the number of previous victims that was used for prioritization. ${ }^{36}$ Finally, Panel D residualizes the outcomes from municipality-specific linear trends. Following Borusyak et al. (2021), we estimate the municipality-level trends using the untreated observations. Our baseline estimates are robust to these alternative specifications in terms of both magnitude and statistical significance.

Regarding the effect of humanitarian demining on nighttime luminosity, Column 1 suggests that, relative to the control buffers that are not-yet-treated or never treated, nightlights increase by $12.4 \%$ on average, in the three years after a demining event. ${ }^{37}$ For comparison, when we use a radius of the size of the average Mozambican municipality, the estimated effect of demining on nighttime lights is about two-thirds of the one found by Chiovelli et al. (2019) for that country, and their point estimate lies within our confidence interval. ${ }^{38}$ Consistent with the finding reported in Column 1, Column 2 shows that population density also increases after demining. It does so by $2.7 \%$ when compared to the sample average.

How does the increase in nighttime light density, triggered by humanitarian efforts to clear landmines, translate into more traditional metrics of economic performance? We answer this question by computing the share of the municipal area affected by $5 \mathrm{Km}$-radius buffers around demining events in the median municipality and multiplying it by the estimated average surge in nighttime lights as reported in Column 1. We then take the product of the resulting number and the median elasticity of GDP to nighttime luminosity, as estimated by Henderson et al. (2011) $(=0.3)$. This back-of-the-envelope calculation suggests that a humanitarian demining event increases the municipal GDP by $0.8 \%$ per year.

In turn, this figure can inform a cost-benefit analysis in which we compare the median municipal value-added to the cost of humanitarian demining per square meter and the size of

${ }^{35}$ The set of characteristics includes buffer-level temperature, precipitation, altitude, distance to the closest river, and distance to the closest National Park.

${ }^{36}$ The set of broader municipal characteristics includes the number of landmine victims over population, the logarithm of population, a coca suitability index, distance to the country's capital, a rurality index, a poverty index, the number of guerilla attacks, and the number of government attacks, all of them measured before the treatment takes place.

${ }^{37}$ As suggested by Bellemare and Wichman (2020), we compute the percentage change in the outcomes subject to a hyperbolic sine transformation as $e^{\hat{\beta}}-1$. In Appendix Table A5, we show that the results are robust to using other transformations of nighttime lights.

${ }^{38}$ One potential driver of this increase in nighttime lights can be an increase in electrification after humanitarian demining. Using municipality-level data, we estimate a difference-in-differences model for municipalities with humanitarian demining before and after 2013. We find a positive non-statistically significant increase in the number of electricity subscribers per capita (see Appendix Table B1). We use this point estimate, 0.005, and the relationship between nighttime lights and electricity subscribers, 1.293 , and find that the increase in subscribers can only explain at most $5.1 \%(=0.005 * 1.293 / 0.127)$ of the estimated effect of humanitarian demining on nighttime lights. 
the average demined area. ${ }^{39}$ Following this procedure, we find that the benefit/cost ratio is 7.1. That is, humanitarian demining increased income by over seven dollars per invested dollar. This is likely a lower bound as it considers only the benefits realized the year after the humanitarian demining takes place, and does not take into account the learning gains that we document next.

The positive effects of humanitarian demining are not limited to economic activity. For instance, we also find that students' performance in national standardized tests improves after demining events that take place in the vicinity of the school. In particular, we find an increase in the share of students with satisfactory performance in the math (reading) test of 6.7 (8.1) percentage points (Columns 3 and 4 of Table 1, respectively). This increase is statistically significant, and its magnitude is large: it translates to a $32 \%(36 \%)$ increase in the probability of getting a satisfactory grade in math (reading) relative to the sample mean. In Appendix Table A6, we present the results of the effects of demining on grade-specific test scores. Interestingly, the magnitude of the effect is larger for younger students, especially for the math test. In the next section, we explore the potential mechanisms of the positive effect of humanitarian demining on students' performance. In particular, we study the channels related both to changes in the composition of the student population and to learning.

Humanitarian demining also reduced forest loss, albeit by a small and non-significant magnitude (Column 5). In contrast, the reduction that it caused in the size of illegal coca crops, the first activity in the chain of cocaine traffic to the US and other consumption destinations, is large and significant. As shown in Column 6, after a demining event in the vicinity, the area cultivated with coca decreased by $10.4 \%$.

5.2 Demining in military operations Table 2 follows the same structure as Table 1 to study the effect of demining events that result from military operations on the same set of outcomes. One potential identification concern for this type of demining activity is that it may respond to the dynamics of conflict through the deployment of military ground operations, thus confounding the estimates of the effect of landmine removal. To (partially) address this concern, the estimates of Panel $\mathrm{C}$ include as controls two measures of the intensity of conflict in the previous year, as measured by the number of attacks perpetrated by the army and the guerrillas.

This demining treatment has no robust effect on nighttime light density (Column 1). It is positive and significant only when covariates are added in a doubly robust way in Panels B

\footnotetext{
${ }^{39}$ We use the municipal value-added since Colombia has no official GDP statistics at the municipality level. However, the correlation between these two variables at the department level (the smallest administrative unit for which GDP figures are available) is 0.81, and it is strongly significant. We obtained the median cost of demining per square meter-COP 66,700 (=\$18)-from Mutual-Co (2021). The actual cost, however, varies substantially depending on how isolated the areas are.
} 
and C (Sant'Anna and Zhao, 2020). When no covariates are added or when the outcome is residualized from municipal-specific trends, the point estimates are nearly zero. We conclude that demining in military operations does not affect nighttime luminosity in a robust way. In contrast, it does significantly decrease population density by $2.9 \%$ when compared with the sample average (Column 2).

Demining activity in military operations has no robust effect on students' performance in math test scores (Column 3) and seems to reduce the performance in reading test scores by a small magnitude (Column 4). However, this is not robust to the inclusion of bufferspecific geographic covariates in a doubly-robust fashion (Panel B). Nonetheless, this demining treatment does increase deforestation in treated buffers in a magnitude equivalent to $29.4 \%$ (Column 5), and it also reduces coca crops by $9.2 \%$ (Column 6 ).

The different effects of humanitarian and military demining can be explained by: i) the different nature of the treatments, ii) differences in the areas targeted by one type of treatment or the other, iii) or differences in the intensity of demining (with military demining focusing on fewer mines because not focused of declaring entire areas as mine-free). We discuss the first source of difference in detail in section 2. In particular, we emphasize that, in contrast to demining as a byproduct of military operations, humanitarian demining entails working closely with affected communities and clearing entire areas of the threat of landmines.

In an attempt to clean the second (selection) channel and make the two treatments more comparable, we perform two tests aimed at increasing the overlap in the characteristics of the areas subject to humanitarian and military demining. First, we estimate a LASSO model following Belloni et al. (2014) where the dependent variable takes the value of one if the area was subject to humanitarian demining. ${ }^{40}$ Once we uncover the variables that best predict the treatment, we estimate the propensity score and follow Crump et al. (2009) to truncate the sample to increase overlap and re-estimate our baseline model on the common support. Second, we select groups composed of three to ten covariates based on all possible combinations to construct the propensity score, then truncate the sample and re-estimate the model within each underlying common support, thus obtaining a distribution of treatment effects. In Appendix Table A7, we present the estimates from the first approach. We find that humanitarian demining increases nighttime lights in a magnitude that is twice as large as the increase experienced after military demining. ${ }^{41}$ Similar patterns emerge for population density and students' performance, but for deforestation and coca cultivation, the effects are

\footnotetext{
${ }^{40}$ The list of right-hand-side variables includes: a poverty index, the logarithm of population, the distance to the closest department's capital, a coca suitability index, the distance to the country's capital, the distance to the closest national park, a rurality index, elevation, precipitation, and temperature.

${ }^{41}$ The standard errors of the common support sub-sample are, however, somewhat large and thus the difference is not statistically significant at conventional levels.
} 
larger in the case of military demining. Appendix Figure A4 reports the results obtained with the second approach, which leads to similar conclusions. This analysis is suggestive of the potential lack of selection. One caveat is that, in contrast to humanitarian demining, military operations (whether or not producing partial demining activity) are likely to take place in areas affected by conflict. However, this concern is partly addressed with the inclusion of various proxies of the prior intensity of conflict (recall the discussion of Panel C).

To address the last alternative, we identify clusters of demining events in military operations that are close in time and space to one another and that, collectively, resulted in at least as many mines subtracted as the median mine removal in humanitarian demining events. Then, within that sub-sample, we re-estimate our baseline specification. The results are reported in Appendix Table A8. They are very similar to those obtained using the full sample of demining events in military operations.

Overall, this evidence is consistent with the idea that the stark differences regarding the effects of different types of demining efforts are mainly explained by the large heterogeneity in the nature of the treatments, rather than by differences in the targeted areas or in the intensity of the demining activity.

5.3 Main identifying assumption The main assumption of the validity of Callaway and Sant'Anna (2021)'s approach to identifying causal effects is that, in the absence of the treatment, the evolution of the potential outcomes would be the same for the treated cohort $(g)$ and the never-treated or soon-to-be-treated units. To partially assess the validity of this assumption, we present the event-study version of the estimated ATTs, aggregated according to the relative time to the demining event.

Figure 2 reports Callaway and Sant'Anna (2021)'s event study of the effect of humanitarian demining on the outcomes of interest. ${ }^{42}$ We find that, before the treatment, the coefficients tend to move around zero and show no discernible differential pre-treatment trend. This is particularly so for nighttime lights (Panel A) and students' performance (Panels C and D). ${ }^{43}$ There seems to be a drop in (relative) year -1 in the differential level of coca-growing (Panel F), which leads us to interpret the findings associated with this outcome with caution. Likewise, Figure 3 suggests that, for the case of demining in military operations, most of the outcomes lack differential pre-trends. The exception is forest loss, for which the differential

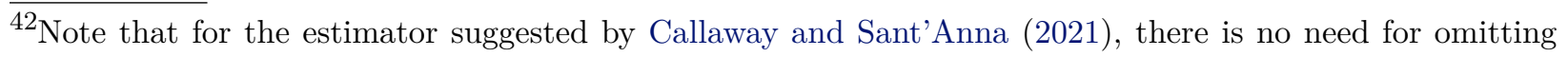
relative year -1 as in the usual difference-in-differences regression with two-way fixed effects. This is because the point estimates of the pre-treatment period are weighted averages of differences between year $t$ and $t-1$ across treated units and their relevant comparison group.

${ }^{43}$ The immediate surge in students' performance cannot only be explained by the effect of humanitarian demining of students' learning. In the next section, we posit that mine clearance generates migration dynamics that likely explain this effect through changes in the composition of students in treated schools.
} 
trend is slightly decreasing prior to the demining event.

We complement the event study figures with a formal test of whether the pre-treatment trends are parallel. Following Roth (2022), we use the precision of our estimates in the pre-treatment period to compute the pre-trend that has a $50 \%$ power of being detected, as well as the adjusted pre-trend that takes into account the pre-testing bias that arises from the fact that the reported analysis is conditional on passing a pre-test. We report the average biases in Appendix Table A9. ${ }^{44}$ The results suggest that, for the case of the humanitarian demining treatment, the size of bias is similar to the magnitude of the estimates for population density and coca cultivation (see Panel A). This suggests that the finding that humanitarian demining increases population density and decreases coca cultivation should be interpreted with caution. For the case of demining as a byproduct of military operations, we do not find large biases for any of the outcomes.

Finally, we follow Rambachan and Roth (2021) and estimate the 90\% confidence set for our parameters of interest after allowing for linear and non-linear deviations from the parallel trends assumption. We estimate such confidence set for the reported coefficient of the year after the demining event. In the case of non-linear deviations, we allow the change in the trend from consecutive periods to be as large as the size of the pre-trend that has a $50 \%$ power of being detected given the precision of the estimates in the pre-treatment period (as in Roth, 2022). Appendix Figure A1 reports the confidence sets resulting from the two treatments. In most of the cases, we find significant results even after allowing for a linear deviation of the parallel trends assumption $(M=0)$. When we allow for non-linear deviations -i.e., the trend can change size and sign for consecutive periods $(M>0)$-we find that the increase in nighttime lights and students' test performance after humanitarian demining is robust. In the case of demining resulting from military operations, we find that significant baseline estimates are robust to both linear and non-linear violations, with the exception of coca cultivation which is only robust to the former.

5.4 Robustness Our results are robust to a battery of additional tests, that we present and thoroughly discuss in section B of the Appendix. These include using other estimation methods such as those proposed by Borusyak et al. (2021), De Chaisemartin and d'Haultfoeuille (2020), and Wooldridge (2021); allowing for spillover effects that take into account the potential spatial correlation of the outcomes analyzed; accounting for potential anticipation effects by excluding from the comparison group the observations that occur one

\footnotetext{
${ }^{44}$ This is the average of the hypothesized trend that goes from (relative) year 0 to year 3 , as well as the average of the pre-testing bias-adjusted trend.
} 
year prior to the demining events; using alternative comparison groups such as the "notyet-treated' or the 'never treated' only; using alternative buffer sizes of 3, 4, 6, and 7Km; excluding demining events in the proximity of areas of interest; and removing outliers.

\section{MeChanisms}

In this section, we explore the potential mechanisms behind the heterogeneous local effects of the different demining treatments. In particular, we study: i) the role of local road connectivity and market access in promoting economic activity and school performance after humanitarian demining events; ii) the role of composition and learning channels in explaining the positive effect of humanitarian demining on students' performance; iii) the differential effects of demining on deforestation in areas with different types of soil suitability; iv) the complementarity of the demining efforts with other policies that seek to promote rural development, particularly with a recent illegal crops substitution program.

6.1 Road connectivity and market access We start by exploring potential heterogeneous effects of the documented impact of humanitarian demining efforts on nighttime light density and on students' performance. The potential economic benefits of demining are likely exacerbated if the clearance takes place in areas that are more connected to local markets through a network of roads. Once the mobility restrictions that landmines impose are lifted, better access to inputs, markets for goods and services, and labor opportunities, result in a faster and higher pick up of key economic and social activities. We explore this hypothesis with two different but complementary approaches. First, we use a reduced-form procedure that exploits a rich network of geo-located paved and unpaved roads, available for the entire country and measured in 2012. Second, we leverage on a market access general equilibrium framework following the original contribution of Donaldson and Hornbeck (2016) as well to the application of Chiovelli et al. (2019) to a setting similar to ours. This allows us to estimate the economy-wide effects of humanitarian demining under the assumption that it lifts all mobility restrictions across the previously mined roads.

For the reduced-form approach, we follow the strategy proposed by Marcus and Sant'Anna (2021) to estimate heterogeneous effects in settings of difference-in-differences with staggered adoption. We thus re-estimate our baseline specification on two mutually exclusive samples of demining events: those that occurred in more connected areas and those that took place in less connected places. To that end, we use two different measures. The first one exploits the extensive margin of connectivity and looks at demining events in areas with at least one (paved or unpaved) road that passes within 100 meters of the demined area. The second one exploits the intensive margin, as parametrized by the length of all roads that cross within 100 meters of the demined area. In this case, we use the median of the empirical road length distribution to separate places with high and low connectivity. 
Table 3 reports the results from this exercise. Based on the extensive margin of connectivity, we find that the increase in nighttime lights following a demining event is $18.5 \%$ in areas with at least one road close to the centroid (Panel A, Column 1). In contrast, the effect of demining on nighttime light density is less than half in areas with no road nearby (Panel A, Column 2). A similar pattern is found for students' performance, with the positive effect of demining being larger in more connected areas, even though the difference between the two samples is not statistically significant at conventional levels (Columns 1 and 2 of Panels B and $\mathrm{C}$ for math and reading test scores respectively). The results are quite similar when we exploit the intensive margin of road connectivity (Columns 4 and 5 of Table 3). In this case, the effects of demining on the performance of students are significantly larger in relatively more connected areas, which is consistent with the interpretation that the risk of a landmines explosion prevents children from going to school. Indeed, the available anecdotal evidence suggests that, in several parts of Colombia, landmines are an important obstacle to accessing schools (CNMH, 2017). ${ }^{45}$

Regarding the market access framework, we estimate Donaldson and Hornbeck (2016)'s loglinear reduced-form relationship between aggregate welfare and market access. ${ }^{46}$ The purpose of implementing this model is to understand whether there are general equilibrium effects from humanitarian demining that increase connectivity and potential trade across regions. Section $\mathrm{C}$ in the Appendix summarizes our empirical approach.

Table 4 summarizes the results. Columns 1 to 3 include the log of market access as the main regressor, while columns 4 to 6 include the cell-specific cumulative number of demining events instead. This allows us to study the direct effects of demining. Columns 7 to 9 include both variables. Columns, 1, 4, and 7 only control for cell and year fixed effects. Columns 2, 5, and 8 add the department-year fixed effects. Finally, columns 3, 6, and 9 control for spatial correlation that changes over time by adding a cubic polynomial in latitude and longitude interacted with the time fixed effects (Donaldson and Hornbeck, 2016). Our preferred specification (column 3) implies a luminosity-to-market-access elasticity of 0.25 . That is, a one-standard-deviation increase in market access is associated with a 25 percent increase in nightlight density. Importantly, the magnitude of the estimated elasticity is quite similar to the 0.3 found by Donaldson and Hornbeck (2016) and equal to the 0.25 of Chiovelli et al. (2019).

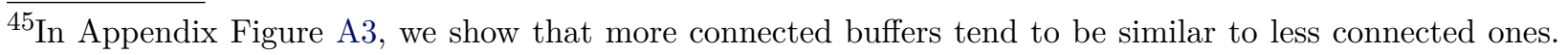
Thus, alleviating concerns that this heterogeneity analysis is capturing other characteristics such as population density or agricultural suitability.

${ }^{46}$ See Donaldson and Hornbeck (2016) for details about the model's assumptions and the derivation of the reduced-form relationship.
} 
When adding cumulative demining as our treatment variable, we find results that are consistent to those obtained from our main specification, which uses as a comparison only places that are known to host landmines. Specifically, and focusing on Column 6, we find that moving from no demining to the mean of the cumulative mine clearance (3.5) increases nighttime lights by 7 percent. Finally, when we add both the log market access and cumulative demining as dependent variables, we find that the elasticity of nighttime lights to market access decreases to 0.21 (Column 9). However, the estimate of the effect of cumulative demining remains largely unchanged. This suggests that humanitarian demining efforts yield both direct and spillover effects on economic activity.

Finally, we leverage on the estimated elasticity of nightlights to market access to conduct a counterfactual exercise similar to that proposed by Chiovelli et al. (2019). Specifically, we compare Colombia's current GDP (with the demining policy actually implemented) with the figure that would result from a counterfactual scenario with no humanitarian demining. For the latter, we use a market access measure based on the 2012 road network (that includes all planted landmines) and we keep fixed the 2012 distribution of nighttime lights to attribute their 2019 counterpart. We then compare the resulting counterfactual values with the actual 2019 market access values that were shaped by the observed demining. Specifically, for this comparison, we sum across localities the exponential difference of the factual and counterfactual market access values multiplied by our estimated nightlight-to-access elasticity of 0.25 (see Column 3 of Table 4). We obtain that, absent any humanitarian effort, nighttime luminosity would have been 17 percent lower between 2013 and 2019. Moreover, using the GDP to nighttime lights elasticity of 0.3 (computed by Henderson et al., 2011), this implies that, over that period, Colombia grew an additional 5.1 percent thanks to humanitarian demining. This equates to a yearly average additional growth of 0.7 percent. Interestingly, this estimate is remarkably similar to that suggested by Chiovelli et al. (2019) for Mozambique (which lies in the range of 0.7 to 1 percent per year).

6.2 Students' composition and learning The positive effect of humanitarian demining on students' performance in math and reading tests, which takes place across different school grades is in line with recent findings that document the effect of Colombia's recent peace agreement on educational outcomes, which improved more than proportionally in areas that experienced landmine explosions before the permanent ceasefire that preceded the agreement (Prem et al., 2021b). In our setting, the progress of students' performance could potentially be accounted for by mechanisms pertaining to both school's composition and students' learning. In particular, because improvements in learning likely take time to materialize into better performance, the immediate effect of humanitarian demining on the performance of students in math and reading tests (reported in Panels C and D of Figure 2) 
is presumably also driven by a school composition effect.

Consistent with this idea, recall that humanitarian demining increases population density (see Table 2, Column 2), which implies that the surges in safety that demined areas experience attract more people. This is in turn probably driven by formerly displaced households who return to their land, as evidenced by the fact that cleared areas experience an increase in land restitution requests followed by the Land Restitution Unit. ${ }^{4}$ Because households who flee away from violence tend to have higher levels of human capital relative to those who stay (Chiovelli et al., 2021), the conflict-driven negative selection translates into a positive selection of returning students after demining. ${ }^{48}$

As evidence for the composition channel, in Table 5, we document that humanitarian demining increased school enrollment by $34 \%$ (Column 1). ${ }^{49}$ This translates into a differential increase in the number of students taking the standardized test (Column 2). Using the estimated increase in enrollment, we can see how much of the estimated change in the share of students with satisfactory performance is driven by a composition effect. If we assume that all the newly enrolled students pass the test, the increase in enrollment would explain $49 \%$ and $37 \%$ of the effects that we find in math and reading tests.

Humanitarian demining also increased by 4.4 percentage points the probability that a new school opened in the treated buffer (Column 3 of Table 5). Note that if the marginal student who did not have access to schooling has lower ability than the average existing student, then constructing an additional school may generate a negative selection in the student population unless most additional students are higher ability returnees. However, if the negative selection effect dominates, this would constitute a force in the opposite direction of our estimated results of the effect of humanitarian demining on academic achievement.

Regarding the effect of humanitarian demining on the production function of students' learning, we find that the students-to-teachers ratio decreased effectively reducing class size (Column 4 of Table 5). This is likely due to the safer environment brought by the complete landmine clearance, that attracts disproportionally more teachers to these areas. Indeed, one of the most dismal consequences of violence in Colombia is the de facto expulsion of teachers from affected areas (Bautista and González, 2019). Moreover, the share of students who passed to the next grade also increased differentially (Column 5). Finally, the fact that

\footnotetext{
${ }^{47}$ Results available upon request.

${ }^{48}$ While location-specific assets make migration costlier, high levels of human capital mitigate migration costs (for instance by reducing the cost of finding a job upon settlement, Becker, 2009; Fischer et al., 2021).

${ }^{49}$ Though not reported, the additional enrollment is driven by that taking place in the (mandatory) elementary and middle school grades, which include the grades in which the standardized national tests studied in this paper are implemented (third, fifth, and ninth). Instead, we see no differential increase in the enrollment in neither preschool nor high-school.
} 
the increased performance of students is larger in the demined areas that are closer to the road network is consistent with a reduction in school absenteeism, which also likely generates learning improvements. Figure A5 shows the event-study counterparts of the outcomes reported in Table 5. The immediate (contemporaneous to the demining year) increase in enrollment and decrease in the students-to-teachers ratio are consistent with the complementarity of composition and learning mechanisms explaining the effects of humanitarian demining on students' performance.

Finally, we explore the extent to which the impact of humanitarian demining on academic achievement is larger for demining events that take place in the proximity of schools. To that end, we follow Marcus and Sant'Anna (2021) and re-estimate the baseline specification on two separate samples: one that includes humanitarian demining instances within 100 meters of a school only, and one that looks at all other humanitarian mine clearance events. Appendix Table A10 summarizes the results. The probability of receiving a satisfactory grade in the math test is 85 percent higher after a demining event in the proximity of a school. For the case of the language test, the probability is 43 percent higher. ${ }^{50}$ This heterogeneity is consistent with a learning effect facilitated by freeing schools from the threat of nearby explosives.

6.3 Deforestation, soil suitability, and extractive activities To shed light on relevant underlying mechanisms behind our results regarding the effects of demining on deforestation, we explore the potential heterogeneous effects that demining in military operations have on deforestation according to the extent to which the soil is suitable to specific extractive activities such as oil palm crops, cattle herding, and rubber crops (Indepaz, 2008; Indepaz, 2020). To that end, we exploit rich information about soil suitability at the level of $30 \mathrm{~m}^{2}$ grids. Based on that input, we build average suitability measures within the $5 \mathrm{Km}$ buffer around all the demining events of our sample. We then split the sample of demining events into those that took place in areas highly suitable for specific land use, as well as those that took place in low-suitability areas. We do so based on the empirical distribution of buffer-specific average suitability.

Table 6 reports the results from this analysis. The results are compelling in suggesting that the effect of demining on deforestation is driven by its occurrence in areas highly suitable to extractive activities. For instance, Panel A suggests that the documented post-military demining forest loss is larger in areas more suitable for oil palm. This increase being $60 \%$ in high suitable areas with no effects for low suitable areas. Similar figures are found when looking at the effect of military demining on forest loss in areas suitable to cattle herding

\footnotetext{
${ }^{50}$ Note that while these differences are large and go in the expected direction, splitting the sample makes the estimates somewhat noisier.
} 
(Panels B and C): military demining causes a large forest loss in high cattle-suitable areas, with the effect being around 56\%. We find similar stories for rubber and forestry suitability. ${ }^{51}$ Importantly, the suitability of the land to extractive activities does not exacerbate or attenuate the effects of humanitarian demining on deforestation (Columns 1 and 2), and we do not find any differential forest loss patterns after military demining in areas suitable to non-extractive traditional crops such as rice, maize, and potato (Panel F).

To complement the idea that the change in forest loss can be related to an increase in extractive agricultural activities after military demining, we explore the effect of demining on the incidence of wildfires. ${ }^{52}$ Anecdotal evidence has shown that, in the Colombian context, fires are used to clear forests for cattle ranching and other land-intensive agricultural activities. ${ }^{53}$ Appendix Table A11 documents that demining in military operations caused fires to increase by $3.5 \%$. This is consistent with the increase in forest loss we documented in our baseline analysis (see Appendix Figure A6 for the event study estimates).

We also explore the effect of demining on illegal gold mining, a highly profitable extractive activity that has been widely used by illegal armed actors in Colombia to finance their operation (Idrobo et al., 2014). ${ }^{54}$ Appendix Table A11 shows that humanitarian demining events have no effect on illegal gold mining, neither in the extensive nor in the intensive margin (Columns 1 and 2). In contrast, demining activity in the context of military operations carried out during this period increased both the incidence of illegal gold mining and the extension of this activity (Columns 3 and 4). See Figure A6 for the event study estimates. Overall, the results highlighted in this subsection are consistent with the extensive qualitative evidence suggesting that in the Colombian context, the new rural investors that demining attracts may be associated with illegal armed groups, and particularly paramilitary militias.

6.4 Government programs and coca cultivation Finally, we exploit one of the main milestones of the 2016 peace agreement with FARC. The implementation of an ambitious illegal crops substitution program (PNIS from its Spanish acronym). This program was created in May 2017, 6 months after the peace agreement was ratified by the Colombian Congress. By 2018, it had reached almost 99,000 farmers in 56 municipalities, and twothirds of them had received payments (Garzón et al., 2019) as a reward for having successfully eradicated illegal coca crops and replaced them with a legal alternative. Given the relevance of this program for the rural development prospects of the main cocaine exporter of the

\footnotetext{
${ }^{51}$ The empirical relevance of this mechanism is consistent with the recent findings of Prem et al. (2020), who document a differential increase in deforestation -most likely related to extractive activities-after the start of the ceasefire in municipalities previously exposed to FARC violence.

${ }^{52}$ This is similar to the approach followed by Harding et al. (2022) to study how deforestation is likely to be related to illegal extractive activities.

${ }^{53}$ See for example, https://rb.gy/7w3zr1 and https://rb.gy/w65etf (last accessed 12/5/2022).

${ }^{54}$ The data comes from UNODC estimates of illegal gold mining and is only available since 2014.
} 
world, we study whether the documented effect of demining during peace on the level of coca cultivation can be at least partially explained by the national rollout of the PNIS crop substitution program. To this end, we split our sample for those cohorts treated after 2017 (when PNIS was launched) into the areas where PNIS was present and those with no active crop-substitution policy. Appendix Table A12 summarizes the results. We find that demining decreases coca crops, especially in PNIS-targeted areas. Moreover, the complementarity effect between demining and PNIS is over three times larger for humanitarian demining than for demining in military operations.

\section{Conclusions}

In spite of the tens of millions of planted anti-personnel landmines that persist today worldwide, the enormous stock of manufactured but not yet planted landmines, and the thousands of landmine victims every year, the literature on the economic costs of conflict has surprisingly relegated the study of the economic and social consequences of landmines, as well as that of the potential benefits of demining campaigns. This lack of empirical evidence is at odds with the hundreds of millions that the international community pours every year into demining activities. While recent efforts have highlighted that comprehensive landmine clearance operations result in increased economic activity, we know little about its impact on other socio-economic and about the effects of other types of demining, especially the kind that occurs as a result of military operations. This paper contributes to filling these gaps and thus provides a road map for international organizations interested in demining.

We study the case of Colombia, the country with the highest number of casualties from improvised handmade landmines, and that has engaged in a range of demining activities since 2013. Moreover, we focus on the local effects of demining by taking advantage of a unique dataset that includes the coordinates of both humanitarian demining campaigns and demining events resulting from military operations. Indeed, our data allows us to test several potential mechanisms of the documented reduced-form relationship between demining and economic growth.

Based on recent methodologies developed for difference-in-differences settings with staggered adoption, and exploiting the longitudinal variation of all demining events that took place from 2013 to 2019 in Colombia, we estimate the causal effect of demining on a range of outcomes, including nighttime light density, students' performance in standardized tests, population density, deforestation, and coca-growing.

Consistent with the previous literature, we find that comprehensive humanitarian demining

events that take place after the end of the conflict increase economic activity. However, our paper innovates in important ways. We find that they also increase other variables associated 
with higher welfare, such as population density and students' performance in standardized tests. Importantly, all these effects are significantly larger in areas that are more connected to inputs, goods and services, and labor markets through a denser road network.

Quantitatively, based on both reduced-form and general equilibrium structural estimates, we find that humanitarian demining increases the annual GDP growth rate by around 0.7 percent, and that, consequently, each dollar invested in this policy yields about $\$ 7$ in return. Moreover, Perilla et al. (2022) estimate that, by saving lives, humanitarian demining yields an additional $\$ 2.6$ per dollar invested in targeted municipalities.

However, unlike any previous literature, we document that demining events that occur as a byproduct of military ground operations have at best no impact. Indeed, we find that demining in military operations does not affect economic activity but does seem to increase deforestation, especially in areas that are suitable for extractive economic activities such as cattle ranching. This calls attention to the potential environmental costs of demining.

Altogether, our results highlight the fact that, unless carried out comprehensively and in close contact with the community, demining can, perhaps surprisingly, backfire. This suggests that in order to trigger beneficial economic and social dynamics demining campaigns should be both comprehensive (in terms of mines' clearance) and involve local communities

with, among other initiatives, mine-risk education programs. Importantly, this insight provides lessons for countries that have years to comply with the Ottawa Mine-Ban Convention, as well as for newly mined countries, notably Ukraine.

\section{REFERENCES}

Abadie, A. (2005): "Semiparametric difference-in-differences estimators," The Review of Economic Studies, 72, 1-19.

Acemoglu, D., S. Johnson, And J. A. Robinson (2002): "Reversal of fortune: Geography and institutions in the making of the modern world income distribution," The Quarterly Journal of Economics, 117, 1231-1294.

Acevedo, K. And I. D. Bornacelly Olivella (2014): "Panel municipal del CEDE," . APC (2020): "Recursos de cooperación internacional hacen posible el desminado humanitario en Colombia," .

Arcand, J.-L., A.-S. Rodella-Boitreaud, And M. Rieger (2015): "The impact of land mines on child health: Evidence from Angola," Economic Development and Cultural Change, 63, 249-279.

Bauman, D., T. Drouet, S. Dray, and J. Vleminckx (2018): "Disentangling good from bad practices in the selection of spatial or phylogenetic eigenvectors," Ecography, 41, 1638-1649. 
Bautista, M. and G. GonzÁlez (2019): "Docencia Rural en Colombia: Educar para la Paz en Medio del Conflicto Armado," Fundación Compartir.

Becker, G. S. (2009): Human capital: A theoretical and empirical analysis, with special reference to education, University of Chicago press.

Bellemare, M. F. And C. J. Wichman (2020): "Elasticities and the inverse hyperbolic sine transformation," Oxford Bulletin of Economics and Statistics, 82, 50-61.

Belloni, A., V. Chernozhukov, and C. Hansen (2014): "High-dimensional methods and inference on structural and treatment effects," Journal of Economic Perspectives, 28, 29-50.

Borusyak, K., X. Jaravel, and J. Spiess (2021): "Revisiting event study designs: Robust and efficient estimation," Tech. rep., Working Paper.

Callaway, B. and P. H. Sant'Anna (2021): "Difference-in-differences with multiple time periods," Journal of Econometrics, 225, 200-230.

Camp, M. J., J. L. Rachlow, R. Cisneros, D. Roon, and R. J. Camp (2016): "Evaluation of global positioning system telemetry collar performance in the tropical Andes of southern Ecuador," Natureza \& Conservação, 14, 128-131.

Casanova Ramírez, L. F. ET AL. (2017): "Incidencia del factor de cooperación internacional en los procesos de desminado humanitario de Mozambique y Colombia," .

CERAC (2016): "Un año de desescalamiento: conflicto casi detenido, pero que se resiste a desaparecer," Monitor de desescalamiento del conflicto armado Interno en Colombia, 12.

Champin, J., R. Cortés, J. Kohon, M. Rodríguez, B. I. De Desarrollo, E. Näslund-Hadley, M. C. Ramos, J. R. Paredes, Á. Bolivar, G. WilchesChaux, et AL. (2016): "Desafíos del transporte ferroviario de carga en Colombia," Banco Interamericano de Desarrollo. Colombia.

Chiovelli, G., S. Michalopoulos, and E. Papaionnnou (2019): "Landmines and spatial development," .

Chiovelli, G., S. Michalopoulos, E. Papaioannou, and S. Sequeira (2021): "Forced Displacement and Human Capital: Evidence from Separated Siblings," .

CNMH (2017): La guerra escondida: Minas Antipersonal y Remanentes Explosivos en Colombia, Centro Nacional de Memoria Histórica.

Conley, T. G. (1999): "GMM estimation with cross sectional dependence," Journal of Econometrics, 92, 1-45.

Crump, R. K., V. J. Hotz, G. W. Imbens, and O. A. Mitnik (2009): "Dealing with limited overlap in estimation of average treatment effects," Biometrika, 96, 187-199.

De Chaisemartin, C. And X. D'Haultfoeuille (2020): "Two-way fixed effects estimators with heterogeneous treatment effects," American Economic Review, 110, 2964-96. 
Dell, M. And P. Querubin (2018): "Nation building through foreign intervention: Evidence from discontinuities in military strategies," The Quarterly Journal of Economics, 133, 701-764.

DNP (2021): "Infrastructure and logistics policies in Colombia," Technical note.

Donaldson, D. And R. HornBeck (2016): "Railroads and American economic growth: A "market access" approach," The Quarterly Journal of Economics, 131, 799-858.

Doswald-Beck, L., P. Herby, and J. Dorais-Slakmon (1995): "Basic facts: The human cost of landmines," Tech. rep., International Committee of the Red Cross.

Fick, S. E. And R. J. Hijmans (2017): "WorldClim 2: new 1-km spatial resolution climate surfaces for global land areas," International Journal of Climatology, 37, 4302-4315.

Fischer, P. A., R. Martin, and T. StraubhaAr (2021): "Should I stay or should I go?" in International migration, immobility and development, Routledge, 49-90.

Fundación Seguridad y Democracia (2006): Informe Especial: Conflicto y minas antipersonal en Colombia.

García Duque, J. And J. P. Casadiego (2021): "International cooperation in peacebuilding: stakeholder interaction in Colombia," Third World Quarterly, 42, 2372-2392.

Garzón, J. C., J. D. Gelvez, and J. L. Bernal (2019): "En qué va la sustitución de cultivos ilícitos? Desafíos, dilemas actuales y la urgencia de un consenso," Tech. rep., Fundación Ideas para la Paz.

Gómez Montoya, L. F., L. M. Rangel Díaz, A. Molano, A. Harker, S. Gómez, J. C. Cristancho, et AL. (2018): "Aproximaciones ecológicas al clima escolar en Bogotá: perfiles de riesgo, asociaciones con desempeño escolar y entornos escolares," .

Goodman-BAcon, A. (2021): "Difference-in-differences with variation in treatment timing," Journal of Econometrics, 225, 254-277.

Hall, B. (2017): "Top 10 Facts about Landmines," Tech. rep., The Borgen Project.

Hansen, M. C., P. V. Potapov, R. Moore, M. Hancher, S. A. Turubanova, A. Tyukavina, D. Thau, S. V. Stehman, S. J. Goetz, T. R. Loveland, et al. (2013): "High-resolution global maps of 21st-century forest cover change," Science, 342, 850-853.

Harding, R., M. Prem, N. A. Ruiz, And D. Vargas (2022): "Buying a Blind Eye: Campaign Donations, Regulatory Enforcement, and Deforestation," .

Heckman, J. J., H. IChimura, And P. E. Todd (1997): "Matching as an econometric evaluation estimator: Evidence from evaluating a job training programme," The Review of Economic Studies, 64, 605-654.

Henderson, V., A. Storeygard, And D. N. Weil (2011): "A bright idea for measuring economic growth," American Economic Review, 101, 194-99.

ICFES (2019): "Documentación del examen Saber 11," Tech. rep. 
Idrobo, N., D. MejÍA, And A. M. Tribin (2014): "Illegal gold mining and violence in Colombia," Peace Economics, Peace Science and Public Policy, 20, 83-111.

IndePAZ (2008): "Informe de Paraeconomía y Narcoparamilitares en el 2008," Punto de Encuentro, 52.

(2020): Macrocriminalidad con licencia legal Urabá-Darién 1980-2014.

Landmine Monitor (2017): "Landmine Monitor 2017," Discussion paper, International Campaign to Ban Landmines (ICBL) and the Cluster Munition Coalition (CMC).

- (2019): "Landmine Monitor 2019," Discussion paper, International Campaign to Ban Landmines (ICBL) and the Cluster Munition Coalition (CMC).

- (2021): "Landmine Monitor 2021," Discussion paper, International Campaign to Ban Landmines (ICBL) and the Cluster Munition Coalition (CMC).

Li, X., Y. Zhou, M. Zhao, and X. Zhao (2020): "A harmonized global nighttime light dataset 1992-2018," Scientific Data, 7, 1-9.

LiN, E. (2020): "How war changes land: Soil fertility, unexploded bombs, and the underdevelopment of Cambodia," American Journal of Political Science.

Marcus, M. And P. H. Sant'Anna (2021): "The role of parallel trends in event study settings: An application to environmental economics," Journal of the Association of Environmental and Resource Economists, 8, 235-275.

Martinez, L. R. (2021): "How much should we trust the dictator's GDP growth estimates?" University of Chicago, Becker Friedman Institute for Economics Working Paper.

Merrouche, O. (2008): "Landmines and poverty: IV evidence from Mozambique," Peace Economics, Peace Science and Public Policy, 14, 23-38.

(2011): "The long term educational cost of war: Evidence from landmine contamination in Cambodia," The Journal of Development Studies, 47, 399-416.

Michalopoulos, S. And E. Papaioannou (2013): "Pre-Colonial Ethnic Institutions and Contemporary African Development," Econometrica, 81, 113-152.

Miguel, E. And G. Roland (2011): "The long-run impact of bombing Vietnam," Journal of Development Economics, 96, 1-15.

Munroe, E., A. Nosach, M. Pedrozo, E. Guarnieri, J. F. Riaño, A. Tur-Prats, And F. Valencia-Caicedo (2022): "The Legacies of War for Post-Conflict Ukraine," . Mutual-Co (2021): "External evaluation: Comprehensive mine action in Algeciras. Project NO. 7F-09980.02.01," .

Nunn, N. And D. Puga (2012): "Ruggedness: The blessing of bad geography in Africa," Review of Economics and Statistics, 94, 20-36.

Osorio, J. D. A. (2022): "Cooperación internacional y construcción de paz: miradas históricas y reflexivas sobre Colombia," Razón Crítica.

PAICMA (2012): "Glosario Terminos Accion Contra Minas," . 
PArker, A. (2018): "The Effects of Landmines in Poor Countries," .

Perilla, S., M. Prem, M. Purroy, and J. F. Vargas (2022): "How peace saves lives: Evidence from Colombia," Working Paper.

Prem, M., A. Rivera, D. Romero, and J. F. VArgas (2022): "Selective civilian targeting: The unintended consequences of partial peace," Quarterly Journal of Political Science, 17, 317-354.

Prem, M., S. SaAvedra, And J. F. Vargas (2020): "End-of-conflict deforestation: Evidence from Colombia's peace agreement," World Development, 129, 104852.

Prem, M., J. F. VArgas, And D. Mejía (2021a): "The rise and persistence of illegal crops: Evidence from a naive policy announcement," The Review of Economics and Statistics, 1-42.

Prem, M., J. F. Vargas, And O. Namen (2021b): "The human capital peace dividend," Journal of Human Resources, 0320-10805R2.

Presidencia de la República de Colombia (2018): "Paz con Legalidad 2018-2022," . Rambachan, A. And J. Roth (2021): "An honest approach to parallel trends," .

Riaño, J. F. And F. Valencia Caicedo (2020): "Collateral damage: The legacy of the secret war in Laos," Available at SSRN 3678347.

Romano, J. P. And M. Wolf (2005): "Stepwise multiple testing as formalized data snooping," Econometrica, 73, 1237-1282.

Roth, J. (2022): "Pretest with caution: Event-study estimates after testing for parallel trends," American Economic Review: Insights, 4, 305-22.

SAnt'Anna, P. H. And J. ZhaO (2020): "Doubly robust difference-in-differences estimators," Journal of Econometrics, 219, 101-122.

Stevens, F. R., A. E. Gaughan, C. Linard, And A. J. Tatem (2015): "Disaggregating census data for population mapping using random forests with remotely-sensed and ancillary data," PloS one, 10, e0107042.

Storeygard, A. (2016): "Farther on down the road: transport costs, trade and urban growth in sub-Saharan Africa," The Review of economic studies, 83, 1263-1295.

UN General Assembly (1996): "Impact of armed conflict on children : note / by the Secretary-General," .

UNODC (2020): "Colombia alluvial gold exploitation: Evidence from remote sensing," .

Vargas, J. F., M. E. Purroy, S. Perilla, F. Coy, and M. Prem (2022): "Fear to Vote: Explosions and Elections in Colombia," .

Wooldridge, J. (2021): "Two-way fixed effects, the two-Way Mundlak regression, and difference-in-differences estimators," Available at SSRN 3906345. 
FiguRE 1. Differential characteristics by timing and intensity of the treatment

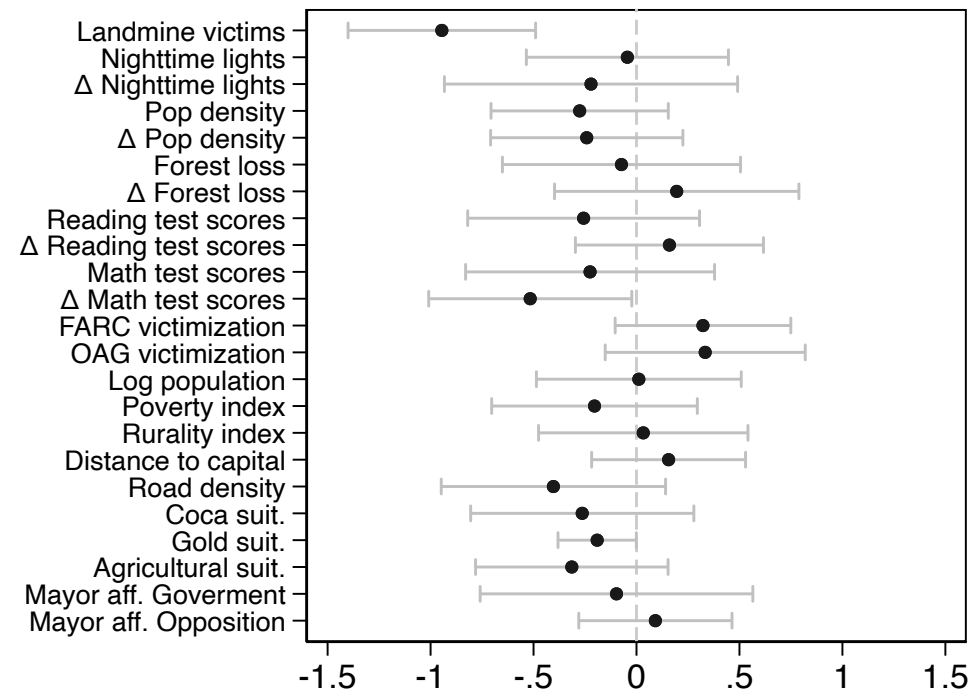

A. Humanitarian: Timing

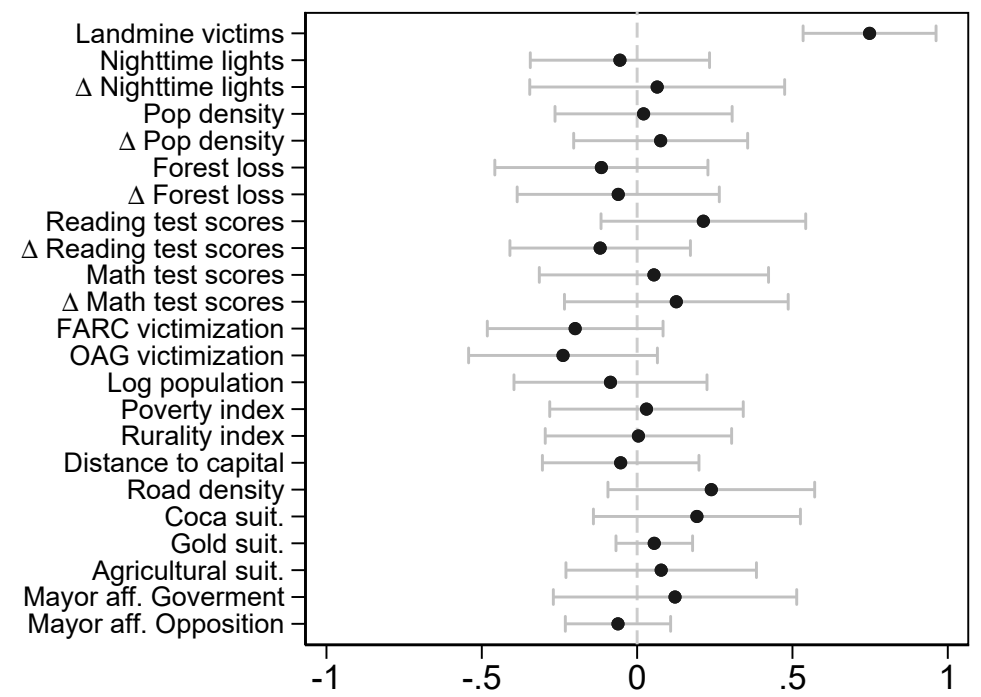

\section{B. Humanitarian: Intensity}

Notes: This figure presents the standardized differences by treatment timing and intensity. The sample is limited to municipalities that experienced any humanitarian demining since 2013. In Panel A, we present point estimates and confidence intervals for a regression of the first year that a municipality experienced humanitarian demining on municipality-level characteristics measured before 2013. For time-varying characteristics, we take the averages between 2010 and 2012. In Panel B, we do the same but in this case, the dependent variable is the logarithm of the total areas assigned for humanitarian demining in the municipality. Variables with a $\Delta$ are first differences of the variable taking an average of two years before 2013. 
FiguRe 2. Humanitarian demining and local activity

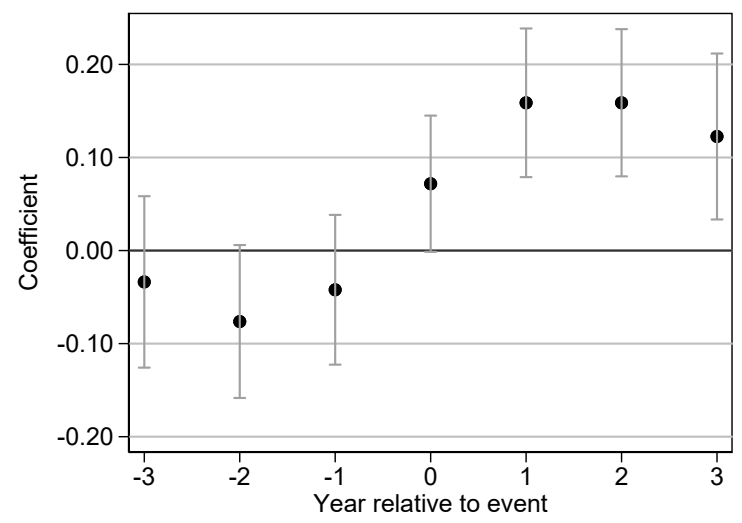

A. Nighttime lights

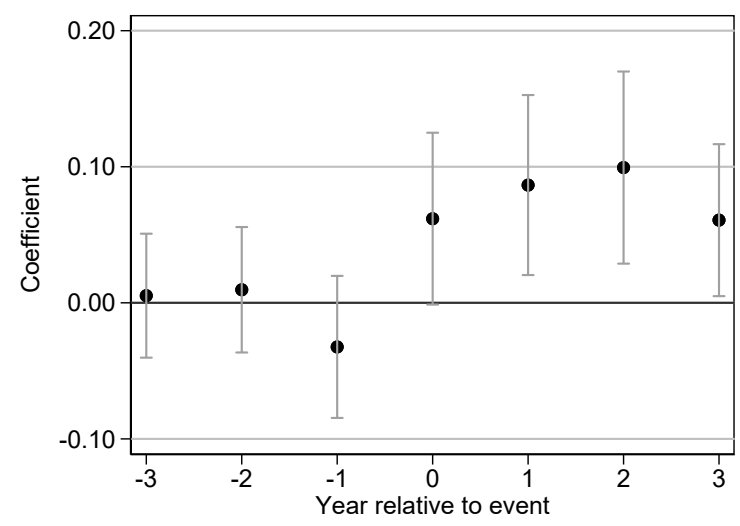

C. Test scores: Math

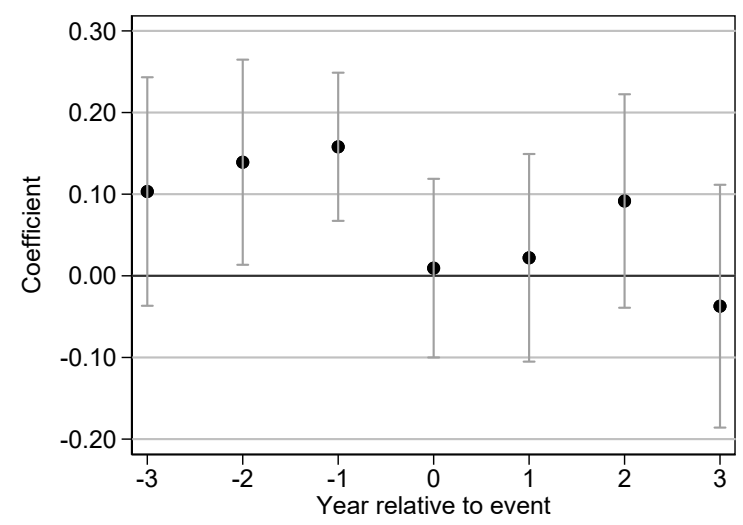

E. Forest loss

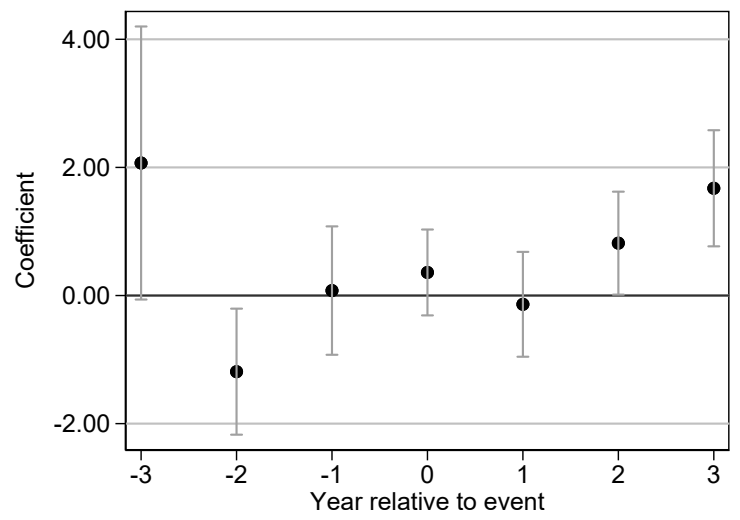

B. Population density

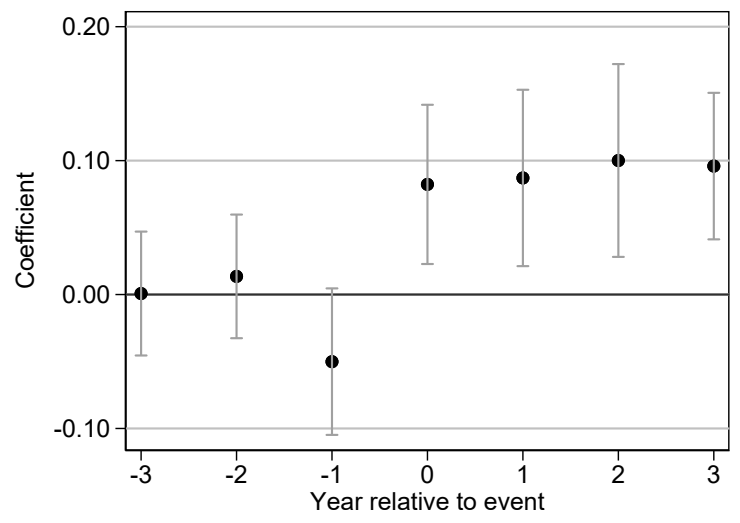

D. Test scores: Reading

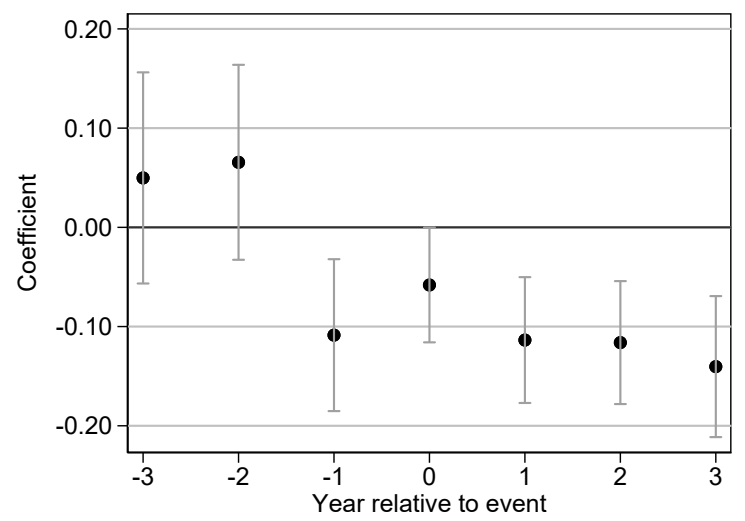

F. Coca

Notes: This figure presents the event study coefficients following Callaway and Sant'Anna (2021) for the treatment of humanitarian demining. We present the point estimates as well as the $95 \%$ confidence interval. Standard errors clustered at the event level. The outcomes were computed using a radius of $5 \mathrm{~km}$ around the demining. 
Figure 3. Military demining and local activity

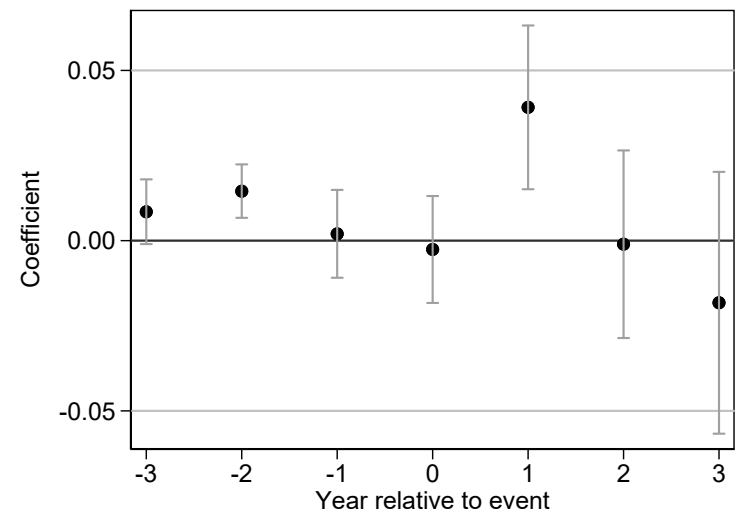

A. Nighttime lights

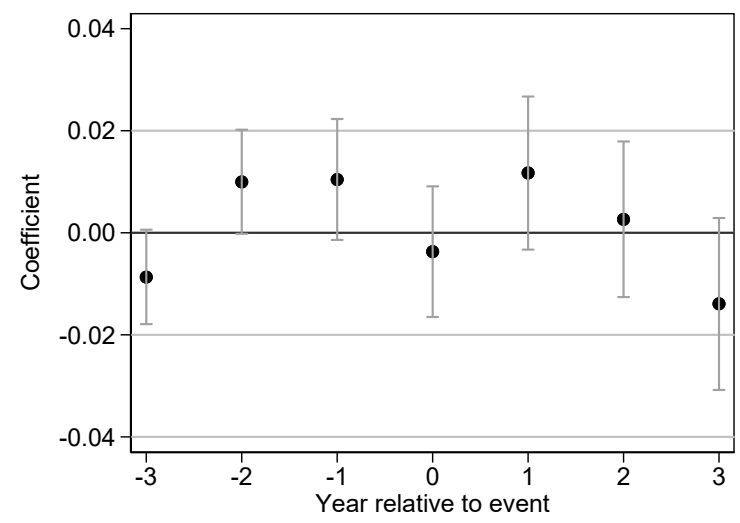

C. Test scores: Math

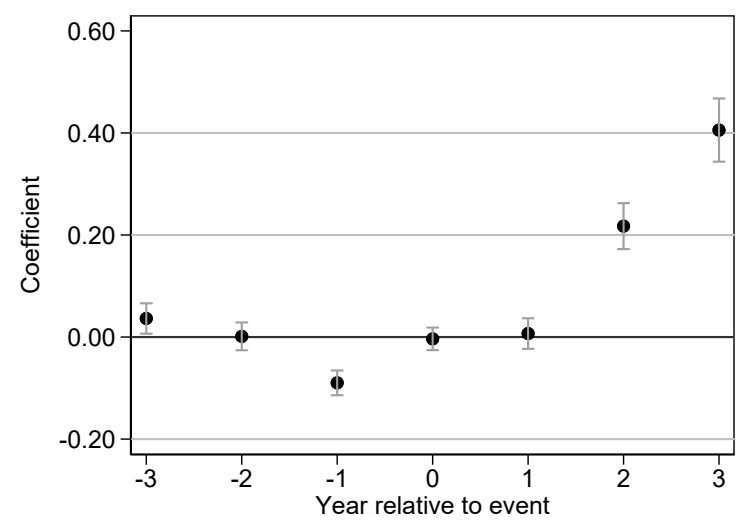

E. Forest loss

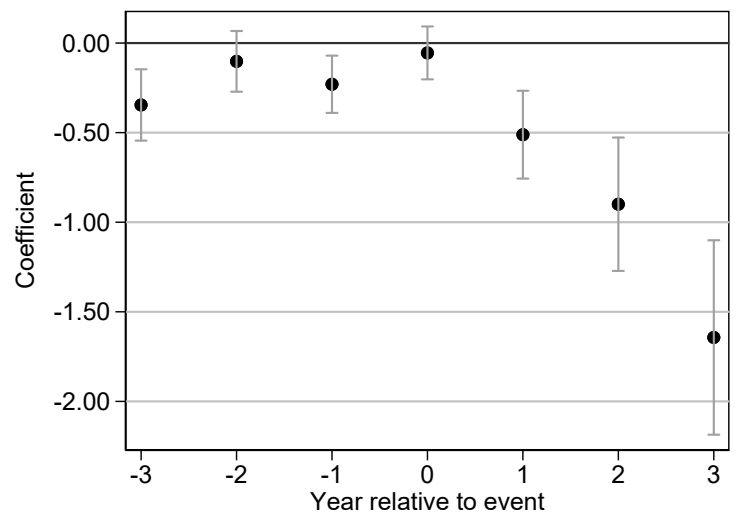

B. Population density

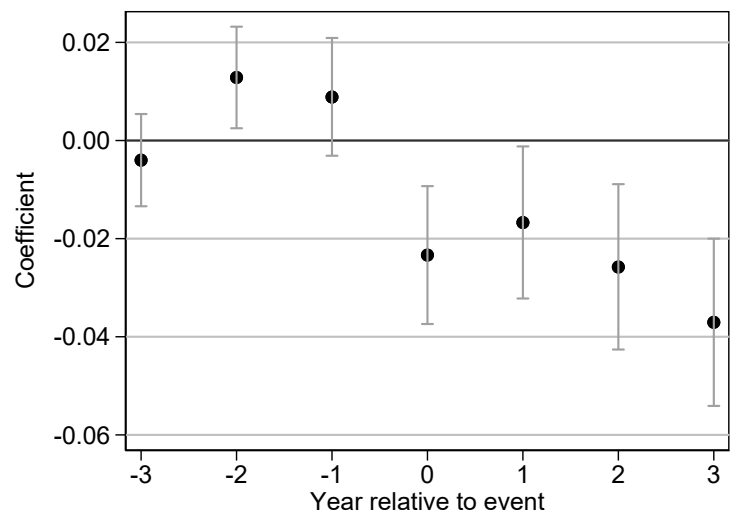

D. Test scores: Reading

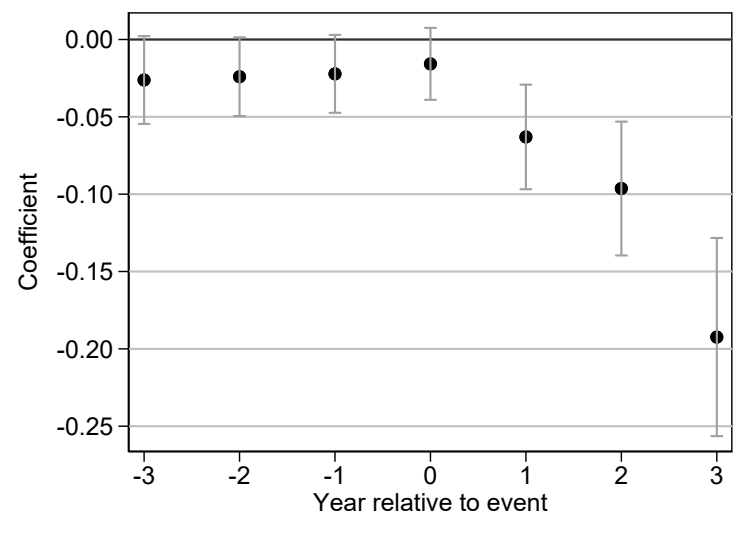

F. Coca

Notes: This figure presents the event study coefficients following Callaway and Sant'Anna (2021) for the treatment of demining during peace. We present the point estimates as well as the $95 \%$ confidence interval. Standard errors clustered at the event level. The outcomes were computed using a radius of $5 \mathrm{~km}$ around the demining. 
TABLE 1. The local effects of humanitarian demining

\begin{tabular}{|c|c|c|c|c|c|c|}
\hline & $(1)$ & $(2)$ & $(3)$ & (4) & $(5)$ & $(6)$ \\
\hline & & & \multicolumn{2}{|c|}{ Test scores: } & & \\
\hline Dep. variable: & $\begin{array}{l}\text { Nighttime } \\
\text { Lights }\end{array}$ & $\begin{array}{c}\text { Population } \\
\text { density }\end{array}$ & Math & Reading & $\begin{array}{c}\text { Forest } \\
\text { loss }\end{array}$ & Coca \\
\hline
\end{tabular}

Panel A: Baseline specification

$\begin{array}{ccccccc}\text { Post demining } & 0.117^{* * *} & 0.938^{* * *} & 0.067^{* * *} & 0.081^{* * *} & -0.031 & -0.110^{* * *} \\ (0.036) & (0.363) & (0.021) & (0.021) & (0.054) & (0.035)\end{array}$

Panel B: Adds geographic covariates

$\begin{array}{ccccccc}\text { Post demining } & 0.094^{* *} & 0.868^{* *} & 0.040^{*} & 0.042^{* *} & -0.078 & -0.094^{* *} \\ (0.046) & (0.352) & (0.021) & (0.020) & (0.049) & (0.037)\end{array}$

Panel C: Adds municipality covariates

$\begin{array}{ccccccc}\text { Post demining } & 0.110^{* * *} & 1.020^{* * *} & 0.046^{* *} & 0.063^{* * *} & -0.049 & -0.104^{* * *} \\ & (0.039) & (0.351) & (0.022) & (0.022) & (0.058) & (0.038)\end{array}$

Panel D: Adds municipality linear trends

$\begin{array}{lcccccc}\text { Post demining } & 0.108^{* * *} & 0.932^{* * *} & 0.067^{* * *} & 0.081^{* * *} & -0.031 & -0.109^{* * *} \\ & (0.036) & (0.350) & (0.022) & (0.021) & (0.052) & (0.036) \\ \text { Observations } & 5983 & 7460 & 6960 & 6960 & 7460 & 7460 \\ \text { Treated } & 291 & 294 & 283 & 283 & 294 & 294 \\ \text { Never treated } & 449 & 452 & 413 & 413 & 452 & 452 \\ \text { Average dep var } & 1.675 & 34.407 & 0.207 & 0.222 & 3.290 & 0.636 \\ \text { MHT p-value } & 0.001 & 0.002 & 0.002 & 0.001 & 0.418 & 0.002\end{array}$

Notes: This table presents the overall ATT following Callaway and Sant'Anna (2021) for the treatment of humanitarian demining during peace. Post demining is the weighted average of all group-time average treatment effects with weights proportional to group size. The set of controls includes not yet treated and never treated. The outcomes were computed using a radius of $5 \mathrm{~km}$ around the demining. In Panels $\mathrm{B}$ and $\mathrm{C}$, we use a doubly robust estimator following Sant'Anna and Zhao (2020). In Panel B, we use geographic covariates to predict the outcome. The set of covariates includes temperature, precipitation, altitude, distance to the closest river, and to the closest national park. In Panel $\mathrm{C}$, we add a set of municipality characteristics as covariates that includes the number of landmine victims over population, the logarithm of population, a coca suitability index, distance to the country's capital, a rurality index, a poverty index, the number of guerilla attacks, and the number of government attacks. In Panel D, we residualized the outcome from municipality linear trends, that are computed using untreated observations. Bootstrap standard errors clustered at the event level. We also present p-values that control for the family-wise error rate in multiple hypotheses testing following Romano and Wolf (2005). * is significant at the $10 \%$ level, $* *$ is significant at the $5 \%$ level, $* * *$ is significant at the $1 \%$ level. 
TABLE 2. The local effects of military demining

\begin{tabular}{|c|c|c|c|c|c|c|}
\hline \multirow{2}{*}{\multicolumn{2}{|c|}{$(1)$}} & \multirow[t]{2}{*}{$(2)$} & $(3)$ & (4) & \multirow[t]{2}{*}{$(5)$} & \multirow[t]{2}{*}{ (6) } \\
\hline & & & \multicolumn{2}{|c|}{ Test scores: } & & \\
\hline Dep. variable: & $\begin{array}{l}\text { Nighttime } \\
\text { Lights }\end{array}$ & $\begin{array}{c}\text { Population } \\
\text { density }\end{array}$ & Math & Reading & $\begin{array}{c}\text { Forest } \\
\text { loss }\end{array}$ & Coca \\
\hline \multicolumn{7}{|c|}{ Panel A: Baseline specification } \\
\hline Post demining & $\begin{array}{c}0.009 \\
(0.013)\end{array}$ & $\begin{array}{c}-0.983^{* * *} \\
(0.220)\end{array}$ & $\begin{array}{l}-0.001 \\
(0.006)\end{array}$ & $\begin{array}{c}-0.016^{* *} \\
(0.006)\end{array}$ & $\begin{array}{c}0.258^{* * *} \\
(0.024)\end{array}$ & $\begin{array}{c}-0.097^{* * *} \\
(0.025)\end{array}$ \\
\hline
\end{tabular}

Panel B: Adds geographic covariates

$\begin{array}{ccccccc}\text { Post demining } & 0.067^{* * *} & -0.907^{* *} & 0.010 & -0.011 & 0.217^{* * *} & -0.093^{* * *} \\ & (0.016) & (0.375) & (0.009) & (0.009) & (0.026) & (0.030)\end{array}$

\section{Panel C: Adds municipality covariates}

$\begin{array}{ccccccc}\text { Post demining } & 0.069^{* * *} & -0.851^{* * *} & 0.005 & -0.017^{*} & 0.070^{* * *} & -0.111^{* * *} \\ & (0.018) & (0.296) & (0.008) & (0.010) & (0.023) & (0.026)\end{array}$

\section{Panel D: Adds municipality linear trends}

\begin{tabular}{lcccccc} 
Post demining & 0.009 & $-0.979^{* * *}$ & -0.001 & $-0.016^{* * *}$ & $0.258^{* * *}$ & $-0.094^{* * *}$ \\
& $(0.013)$ & $(0.227)$ & $(0.006)$ & $(0.006)$ & $(0.024)$ & $(0.025)$ \\
Observations & 90504 & 100560 & 69340 & 69370 & 100560 & 100560 \\
Treated & 9630 & 9630 & 6641 & 6641 & 9630 & 9630 \\
Never treated & 426 & 426 & 293 & 296 & 426 & 426 \\
Average dep var & 0.973 & 33.381 & 0.149 & 0.168 & 3.721 & 2.392 \\
MHT p-value & 0.540 & 0.001 & 0.751 & 0.001 & 0.001 & 0.001 \\
\hline
\end{tabular}

Notes: This table presents the overall ATT following Callaway and Sant'Anna (2021) for the treatment of military demining. Post demining is the weighted average of all group-time average treatment effects with weights proportional to group size. The set of controls include not yet treated and never treated. The outcomes were computed using a radius of $5 \mathrm{~km}$ around the demining. In Panels B and C, we use a doubly robust estimator following Sant'Anna and Zhao (2020). In Panel B, we use geographic covariates to predict the outcome. The set of covariates includes temperature, precipitation, altitude, distance to the closest river, and to the closest national park. In Panel C, we add a set of municipality characteristics as covariates that includes the logarithm of population, a coca suitability index, distance to the country's capital, a rurality index, a poverty index, the number of guerilla attacks, and the number of government attacks. In Panel D, we residualized the outcome from municipality linear trends, that are computed using untreated observations. Bootstrap standard errors clustered at the event level. We also present p-values that control for the family-wise error rate in multiple hypotheses testing following Romano and Wolf (2005). $*$ is significant at the $10 \%$ level, ${ }^{* *}$ is significant at the $5 \%$ level, ${ }^{* * *}$ is significant at the $1 \%$ level. 
TABlE 3. Heterogeneous effects for economic and social outcomes by road connectivity - Humanitarian demining

\begin{tabular}{|c|c|c|c|c|c|c|}
\hline & \multicolumn{2}{|r|}{ Any road } & $(3)$ & (4) $\mathrm{R}$ & Road's density & ty \\
\hline & $\begin{array}{l}\text { Paved or } \\
\text { Unpaved }\end{array}$ & No roads & $\begin{array}{l}\text { p-value } \\
\text { diff. }\end{array}$ & High & Low & $\begin{array}{c}\text { p-value } \\
\text { diff. }\end{array}$ \\
\hline \multicolumn{7}{|c|}{ Panel A: Dep. var.: Nighttime Lights } \\
\hline Post demining & $\begin{array}{c}0.172^{* * * *} \\
(0.051)\end{array}$ & $\begin{array}{c}0.071 \\
(0.046)\end{array}$ & 0.045 & $\begin{array}{c}0.179 * * \\
(0.070)\end{array}$ & $\begin{array}{c}0.084^{* *} \\
(0.042)\end{array}$ & 0.173 \\
\hline \multicolumn{7}{|c|}{ Panel B: Dep. var.: Test scores - Math } \\
\hline Post demining & $\begin{array}{c}0.091^{* * * *} \\
(0.032)\end{array}$ & $\begin{array}{c}0.046 \\
(0.030)\end{array}$ & 0.163 & $\begin{array}{c}0.152^{* * *} \\
(0.040)\end{array}$ & $\begin{array}{c}0.037 \\
(0.026)\end{array}$ & 0.003 \\
\hline \multicolumn{7}{|c|}{ Panel C: Dep. var.: Test scores - Reading } \\
\hline Post demining & $\begin{array}{c}0.095 * * * \\
(0.032)\end{array}$ & $\begin{array}{c}0.070 * * \\
(0.030)\end{array}$ & 0.436 & $\begin{array}{c}0.142^{* * *} \\
(0.037)\end{array}$ & $\begin{array}{c}0.058 * * \\
(0.025)\end{array}$ & 0.023 \\
\hline Observations (Panel A) & 3360 & 4100 & & 1860 & 5560 & \\
\hline Observations (Panel B) & 3240 & 3720 & & 1790 & 5170 & \\
\hline Observations (Panel C) & 3240 & 3720 & & 1790 & 5170 & \\
\hline Treated (Panel A) & 139 & 155 & & 88 & 206 & \\
\hline Treated (Panel B) & 136 & 147 & & 86 & 197 & \\
\hline Treated (Panel C) & 136 & 147 & & 86 & 197 & \\
\hline Never treated (Panel A) & 197 & 255 & & 98 & 354 & \\
\hline Never treated (Panel B) & 188 & 225 & & 93 & 320 & \\
\hline Never treated (Panel C) & 188 & 225 & & 93 & 320 & \\
\hline
\end{tabular}

Notes: This table presents the overall ATT following Callaway and Sant'Anna (2021) for nighttime lights (Panel A) and students' performance (Panels B and C) after a humanitarian demining event. Post demining is the weighted average of all group-time average treatment effects with weights proportional to group size. The set of controls include not yet treated and never treated. The outcomes were computed using a radius of $5 \mathrm{~km}$ around the demining. For each type of treatment, we divide the treated and never treated into events with any paved or unpaved road that crosses as close as $1 \mathrm{~km}$ from the demined area and those with no close roads (columns 1 to 3 ). In columns 4 to 6 , we follow a similar strategy but we divide the events into those that have a higher area of roads, measured by the length of the road that crosses as close as $1 \mathrm{~km}$ from the demined area. We use the median of the empirical distribution to separate those with high and low connectivity. $*$ is significant at the $10 \%$ level, $* *$ is significant at the $5 \%$ level, $* * *$ is significant at the $1 \%$ level. 


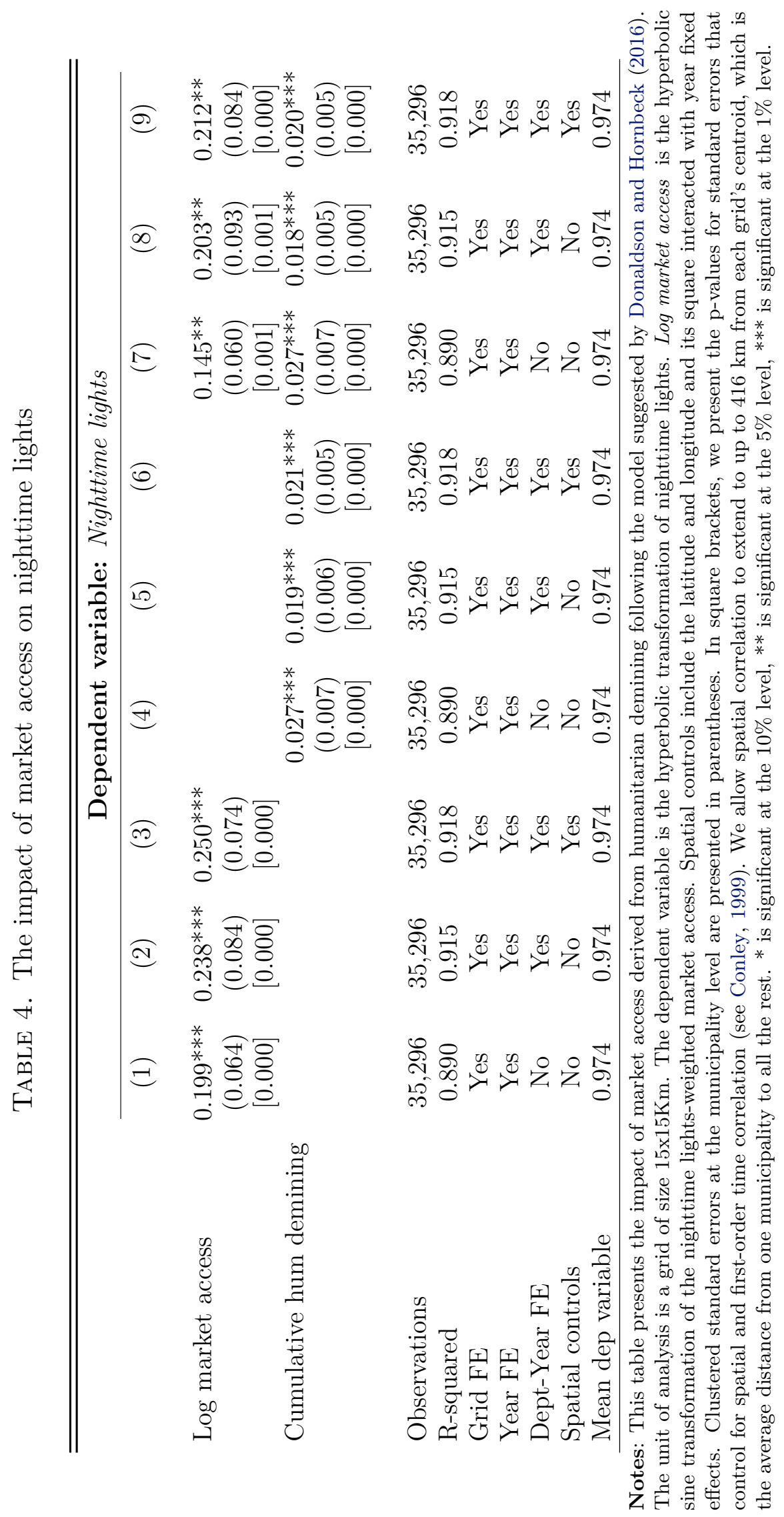


TABLE 5. The local effects of humanitarian demining on other educational outcomes

\begin{tabular}{|c|c|c|c|c|c|}
\hline Dep. variable: & $\begin{array}{c}\text { (1) } \\
\text { Enrollment }\end{array}$ & $\begin{array}{c}(2) \\
\text { Share } \\
\text { Test Taker }\end{array}$ & $\begin{array}{c}(3) \\
\text { School } \\
\text { Entry }\end{array}$ & $\begin{array}{c}(4) \\
\text { Ratio Student } \\
\text { Teacher }\end{array}$ & $\begin{array}{c}(5) \\
\text { Share } \\
\text { Approved }\end{array}$ \\
\hline Post demining & $\begin{array}{c}0.295^{* * *} \\
(0.081)\end{array}$ & $\begin{array}{c}0.076^{* *} \\
(0.033)\end{array}$ & $\begin{array}{c}0.045^{*} \\
(0.025)\end{array}$ & $\begin{array}{c}-0.292^{* * *} \\
(0.075)\end{array}$ & $\begin{array}{c}0.034^{* *} \\
(0.015)\end{array}$ \\
\hline Observations & 6453 & 4513 & 6714 & 5913 & 6714 \\
\hline Treated & 288 & 287 & 294 & 288 & 294 \\
\hline Never treated & 429 & 420 & 452 & 427 & 452 \\
\hline Average dep var & 5.389 & 0.165 & 0.155 & 2.358 & 0.755 \\
\hline
\end{tabular}

Notes: This table presents the overall ATT following Callaway and Sant'Anna (2021) for humanitarian demining during peace. Post demining is the weighted average of all group-time average treatment effects with weights proportional to group size. Enrollment is measured as the logarithm of total enrollment, share of test takers is the number of students taking the national exams over the total number of enrolled students, school entry is a dummy that takes the value one if a school was open within the buffer, ratio student teacher is the logarithm of the students-to-teacher ratio, and share approved is the share of students that advanced to the next grade. The set of controls include not yet treated and never treated. The outcomes were computed using a radius of $5 \mathrm{~km}$ around the demining. Bootstrap standard errors clustered at the municipality level. * is significant at the $10 \%$ level, ** is significant at the $5 \%$ level, $* * *$ is significant at the $1 \%$ level. 
TABLE 6. Heterogeneous effects for forest loss by soil suitability

\begin{tabular}{|c|c|c|c|c|c|c|}
\hline & (1) & $(2)$ & $(3)$ & $(4)$ & $(5)$ & (6) \\
\hline Dep. variable: & \multicolumn{6}{|c|}{ Forest loss } \\
\hline Demining: & \multicolumn{3}{|c|}{ Humanitarian } & \multicolumn{3}{|c|}{ Military } \\
\hline Suitability: & Low & High & $\begin{array}{l}\text { p-value } \\
\text { diff. }\end{array}$ & Low & High & $\begin{array}{c}\text { p-value } \\
\text { diff. }\end{array}$ \\
\hline \multicolumn{7}{|c|}{ Panel A: Oil palm } \\
\hline Post demining & $\begin{array}{c}-0.072 \\
(0.084)\end{array}$ & $\begin{array}{c}0.037 \\
(0.061)\end{array}$ & 0.294 & $\begin{array}{l}-0.015 \\
(0.033)\end{array}$ & $\begin{array}{c}0.472^{* * *} \\
(0.031)\end{array}$ & 0.000 \\
\hline
\end{tabular}

Panel B: Cattle

$\begin{array}{ccccccc}\text { Post demining } & -0.020 & -0.015 & 0.961 & 0.082^{* * *} & 0.450^{* * *} & 0.000 \\ & (0.078) & (0.067) & & (0.030) & (0.035) & \end{array}$

Panel C: Grass

$\begin{array}{lllllll}\text { Post demining } & 0.032 & 0.028 & 0.969 & 0.112^{* * *} & 0.364^{* * *} & 0.000\end{array}$

$\begin{array}{lll}(0.081) & (0.065) \quad(0.027) \quad(0.034)\end{array}$

Panel D: Rubber

$\begin{array}{ccccccc}\text { Post demining } & -0.016 & 0.014 & 0.780 & 0.084^{* * *} & 0.357^{* * *} & 0.000 \\ & (0.087) & (0.063) & & (0.032) & (0.030) & \end{array}$

Panel E: Forestry

$\begin{array}{ccccccc}\text { Post demining } & 0.001 & 0.052 & 0.641 & 0.157^{* * *} & 0.285^{* * *} & 0.005 \\ (0.083) & (0.071) & & (0.032) & (0.032) & \end{array}$

Panel F: Non-extractive traditional crops

\begin{tabular}{|c|c|c|c|c|c|}
\hline Post demining & $\begin{array}{l}-0.091 \\
(0.072)\end{array}$ & $\begin{array}{c}0.024 \\
(0.084)\end{array}$ & 0.299 & $\begin{array}{c}0.295^{* * *} \\
(0.030)\end{array}$ & $\begin{array}{c}0.239 * * * \\
(0.040)\end{array}$ \\
\hline Observations & 3680 & 3780 & & 44660 & 55900 \\
\hline Treated & 125 & 169 & & 4309 & 5321 \\
\hline Never treated & 243 & 209 & & 157 & 269 \\
\hline Average dep var & 2.811 & 3.757 & & 3.147 & 4.179 \\
\hline
\end{tabular}

Notes: This table presents the overall ATT following Callaway and Sant'Anna (2021) for forest loss using the two demining treatments. Post demining is the weighted average of all group-time average treatment effects with weights proportional to group size. The set of controls include not yet treated and never treated. The outcomes were computed using a radius of $5 \mathrm{~km}$ around the demining. For each type of treatment, we divide the treated and never treated into high and low suitability. We do this by constructing the share of the area around the event with suitability for each activity and then defining as high (low) the ones with suitability above (below) the median. The non-extractive traditional crops is a z-score index that includes rice, maize, potato, onion, and pepper. ${ }^{*}$ is significant at the $10 \%$ level, $* *$ is significant at the $5 \%$ level, $* * *$ is significant at the $1 \%$ level. 


\section{ONLINE APPENDIX}

\section{A Additional VARiables And Descriptive STAtistics}

A.1 Soil suitability To study heterogeneous effects based on soil suitability, we build a novel cross-section database by rasterizing -at a resolution of approximately $30 \mathrm{~m} \times 30 \mathrm{~m}$ the suitability zoning shapefiles provided by the Agricultural Rural Planning Unit (UPRA) of the Colombian Ministry of Agriculture. Each pixel contains estimated information on different degrees of suitability for a wide range of activities, based on physical, socio-ecosystemic, and technical factors; socioeconomic and legal criteria; and regulatory guidelines that affect the delimitation of areas according to national level planning and regulation. ${ }^{55}$ We construct information for key activities largely related to deforestation, such as palm oil growing, cattle herding, growing grass used for cattle, rubber crops, banana crops, and forestry. Based on this information, we can create soil suitability at the buffer level using the proportion of the buffer area with suitability for each type of land use.

A.2 Road network We also use detailed information of the location of the entire roads network of Colombia, including all road types from primary (highways) to tertiary (intramunicipal non-paved) roads. These data were obtained from the Instituto Geográfico Agustin Codazzi (IGAC) for the 2012 cross-section.

A.3 Geographic and municipality characteristics We complement the variables described above, used either as the main outcomes or to test potential mechanisms, with weather and geographic characteristics that are geo-referenced at the buffer level. These include temperature and rainfall measures, altitude, distance to rivers and national parks, and the terrain's ruggedness (Nunn and Puga, 2012). ${ }^{56}$ Finally, we also add municipality characteristics from the CEDE municipal panel, compiled by Acevedo and Bornacelly Olivella (2014).

A.4 Summary statistics We start by plotting the intensity of demining across the country, aggregated for the whole period. Appendix Figure B3 plots the spatial distribution of demining events between 2004 and 2019. During this period, there was at least one demining

\footnotetext{
${ }^{55}$ The physical component considers temperature, precipitation, climatic index, adequate depth, soil moisture, nutrient availability, textural class, degree of erosion, slope, landslide susceptibility, flood susceptibility, and volcanic hazards. The socio-ecosystem component includes ecological integrity, land cover, fire hazards, strategic ecosystems, and deforestation. Finally, the socioeconomic component considers institutional framework, security, labor market, living conditions, land size distribution, infrastructure and logistics, cost of rural land, and municipal economic indicators. For a detailed discussion about the weights of each criterion and the construction process, see https://www.upra.gov.co/uso-y-adecuacion-de-tierras/evaluacionde-tierras/zonificacion.

${ }^{56}$ The temperature, rainfall, and altitude data were constructed from Fick and Hijmans (2017), and the distance to rivers and parks was computed based on IDEAM national shapefiles of rivers and national parks.
} 
event in $438(38 \%)$ of the municipalities in Colombia. In Appendix Table A13, we present summary statistics for each outcome variable as measured within the sample buffers used to identify the effect of each of the three demining types. Overall, we find that areas, where humanitarian demining took place, tend to have more intense nighttime luminosity, better students' test performance, and lower levels of coca crops. Population density is larger for areas demined during the post-conflict period (regardless of whether demining took place in military operations or carried out by humanitarian agencies) and forest loss is similar across the three treatments.

In Appendix Figure B4, we show that there are no substantial differences in grid characteristics across demined and not-demined areas within the same municipalities. Likewise, we find no substantial differences regarding the timing of demining events.

\section{B Robustness exercises}

B.1 Other estimation methods In addition to Callaway and Sant'Anna (2021), other econometric procedures have been recently proposed to estimate causal effects in differencein-differences settings with staggered adoption. Our results are robust to using three of them. First, we estimate the effects of demining using Borusyak et al. (2021)'s approach in which the ATT is a weighted average of individual treatment effects. The individual treatment effects are in turn estimated with an imputation technique that recovers the missing (nontreated) potential outcome of the treated units. This counterfactual is constructed using a linear model for untreated observations. ${ }^{57}$ Panel A of Tables A14 and A15 report the overall treatment effects resulting from this estimation procedure ${ }^{58}$ Reassuringly, most outcomes follow the same pre-treatment dynamics (with perhaps a more pronounced decreasing pretrend for the case of population density in military demining). Moreover, in terms of the ATTs, the effects are similar to the baseline estimates reported in Tables 1 to 2 for the three treatments. ${ }^{59}$

The second alternative approach that we explore is the one suggested by De Chaisemartin and d'Haultfoeuille (2020). In this case, the authors compute an ATT that measures the instantaneous treatment effect of moving from being untreated to becoming treated. Panel B of Tables A14 and A15 report the overall ATTs derived from this model ${ }^{60}$. In general, the estimates are of similar magnitude and significance for humanitarian demining, except

\footnotetext{
${ }^{57}$ We use the balanced version of their estimate to avoid results arising from changes in sample composition. ${ }^{58}$ See Figures B5 and B6 in the Online Appendix for the dynamic specification of these procedures.

${ }^{59}$ The magnitudes of the estimates are somewhat smaller for the effect of humanitarian demining on population density and for that of military demining on forest loss. In turn, they are larger for the effect of humanitarian demining on forest loss.

${ }^{60}$ This model yields again no substantial differences in terms of pre-treatment dynamics, see Figures ?? and ?? in the Online Appendix.
} 
for the increase in population density which has half the size found in the baseline estimate. In the case of demining in military operations, the results are also similar to the baseline estimates except for the changes in forest loss, the magnitude of which is half the reported for the Callaway and Sant'Anna (2021) model.

Finally, we estimate a model proposed by Wooldridge (2021), where the estimated ATT is a weighted average of the post-treatment group-year dummies that are estimated with a linear regression over the full sample of three years around the event date. We aggregate the group-year dummies in the same way we do it for the baseline specification and find treatment effects that are similar to those of Borusyak et al. (2021) (see Panel C of Tables A14 and A15).

B.2 Accounting for spillover effects We now explore the presence of spillover effects in our baseline results. Usually, demining is not an isolated event, especially in the case of demining events in military operations, which typically clear entire strategic corridors to allow the ground mobilization of equipment and soldiers from one area to the other. This implies that some of our not-yet-demined controls may soon become demined and thus may contaminate our overall comparison group. We explore the extent of this potential threat to the internal validity of our results with two different but complementary strategies. First, we keep the whole sample and add as a covariate (in a doubly-robust way Sant'Anna and Zhao, 2020) a dummy that identifies whether there was a (one year) prior demining event in the 3,5 , or $7 \mathrm{Km}$ buffer around the current demining event. ${ }^{61}$ Tables A16 and A17 report the results, which prove quite similar to those coming from the baseline specification that accounts for no potential geographic spillover. ${ }^{62}$

Second, we exclude from our estimating sample any demining event that experienced a (one year) prior demining within a 3,5, or $7 \mathrm{Km}$ buffer. Tables A18 and A19 also suggest that this alternative approach to account for potential spillovers yields similar results relative to our baseline specification. ${ }^{63}$

B.3 Alternative comparison groups Recall that our baseline specification uses as a comparison group both the "never-treated" and the "not-yet-treated" mined areas. This section explores the robustness of our results by only using either of the two components. First, Appendix Table A20 reports the average ATTs of the three demining treatments on all

\footnotetext{
${ }^{61}$ We also control for an indicator of whether there was a demining event that intersects with the buffer around never-treated controls during the year prior to the current demining event.

${ }^{62}$ Two exceptions are a smaller and more imprecise estimate of the increase in students' performance in math test scores after humanitarian demining, and a smaller and more imprecise estimate of the decrease of population density after demining in military operations.

${ }^{63}$ One exception is a smaller and more imprecise estimate of the decrease in population density after a demining event in military operation.
} 
the outcomes using only the "never-treated" as the comparison group. The effects of both treatments related to demining in military operations become noisier, which is consistent with this treatment having fewer "never-treated" controls. Second, Appendix Table A21 reports the average ATTs of the demining treatments using only the "not-yet-treated" as the comparison group. Again, the estimates are of similar magnitude and significance but the effects of humanitarian demining on nighttime lights and population density becomes more imprecisely estimated.

B.4 Accounting for anticipation effects We allow for potential anticipation of the demining treatments by excluding from the comparison group the observations that occur one year prior to the demining events. ${ }^{64}$ This is particularly important for humanitarian demining efforts as it may take several months for a targeted area to be fully cleared. Appendix Table A22 shows that the baseline results are robust to allowing for one-year anticipation. The only exception is that now forest loss increases after humanitarian demining.

B.5 Alternative buffer sizes Our results are also robust to changing the size of the buffers that we draw around the geo-referenced demining events to delimit the area within which we study the local effects of demining. Tables A23 and A24 report the average estimates ${ }^{65}$ obtained when defining buffers of radii $3,4,6$, and $7 \mathrm{Km}$. The results are remarkably similar both in terms of size and significance.

\section{B.6 Excluding events close to re-integration areas for ex-combatants One po-} tential concern is that the positive effects we find for humanitarian demining are driven by other public policies that affect these areas. We address this concern by excluding the demining events that happened in the surrounding of the 24 zones that were designated to host FARC ex-combatants after the signing of the peace agreement. In these zones, the government provided job-training, support for productive activities, and security (Presidencia de la República de Colombia, 2018). In Appendix Table A25, we show that the effects are robust to excluding these areas.

B.7 Excluding events close to more populated areas Our results are not driven by the few demining events that are close to relatively more populated areas. ${ }^{66}$ Appendix Figure A7 reports the effect of each demining treatment on each outcome of interest, excluding events that take place within $250 \mathrm{~m}, 500 \mathrm{~m}, 750 \mathrm{~m}$, or $1 \mathrm{~km}$ from the centroid of a populated area.

\footnotetext{
${ }^{64} \mathrm{By}$ doing so, we change the comparison year of the ATT estimates from one to two years before the demining event.

${ }^{65}$ See event study Figures B9 and B10 in Online Appendix.

${ }^{66}$ These areas called centros poblados by the Colombian Statistics Bureau and are the urban centers of the municipalities, where the city hall and other institutional supply is located.
} 
B.8 Outliers In Appendix Table A26, we show that the results are robust to removing outliers by winsorizing the dependent variables at the 1 and $3 \%$ levels of the empirical distribution.

\section{Market acCESS Framework}

Following Donaldson and Hornbeck (2016), we measure welfare using nighttime luminosity and construct a market access measure with the following equation:

$$
M A_{o t} \approx \sum_{d} \tau_{o d t}^{-\theta} L_{d}
$$

where $o, d$, and $t$ stand for origin, destination, and year; $L_{d}$ reflects the average luminosity in the destination; $\tau_{\text {odt }}$ is a measure of transportation costs and $\theta$ is a trade elasticity parameter that we set to 3.88 following the authors.

We compute the above formula using the 2012 road network, that was in place before the beginning of the humanitarian demining efforts. Consistently, we use the 2012 nightlight intensity at the destination. $\tau_{\text {odt }}$ is computed as the shortest path between $o$ and $d$ based on such a network and using Dijkstra's algorithm. ${ }^{67}$ Finally, the network's yearly variation is derived from the demining events that take place on year $t$ within 100 meters of one of the network roads. That is, we abstract from changes in market access due to other reasons, such as the construction of new roads or to changes in economic activity (i.e. nighttime lights) at the destination.

As in Donaldson and Hornbeck (2016), we then employ the estimated market access of each location as the independent variable of the following linear specification:

$$
\ln \left(L_{o t}\right)=\alpha_{o}+\alpha_{s t}+\beta \ln \left(M A_{o t}\right)+\epsilon_{o s t}
$$

where $s$ stands for department. Here, a unit of observation is each $15 \times 15 \mathrm{~km}$ grid cell of the country, and we use the cell centroid's closest road to compute the shortest path. ${ }^{68} \alpha_{o}$ and $\alpha_{s t}$ are cell-specific and department-year fixed effects. $\epsilon_{\text {ost }}$ is an error term clustered at the municipality level -and we also report, in brackets, p-values that account for potential spatial as well as time correlation (Conley, 1999). Our parameter of interest, $\beta$, measures the elasticity between market access and nighttime luminosity. ${ }^{69}$

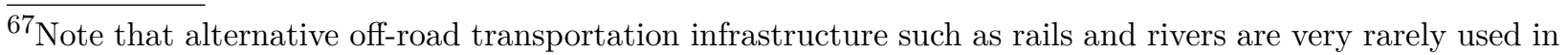
Colombia (Champin et al., 2016; DNP, 2021).

${ }^{68}$ Results are robust to using larger $(20 \times 20 \mathrm{~km})$ grid cells (results available upon request).

${ }^{69} \mathrm{As}$ in Chiovelli et al. (2019), we standardize $\ln \left(M A_{o t}\right)$ to facilitate the coefficient's interpretation.
} 


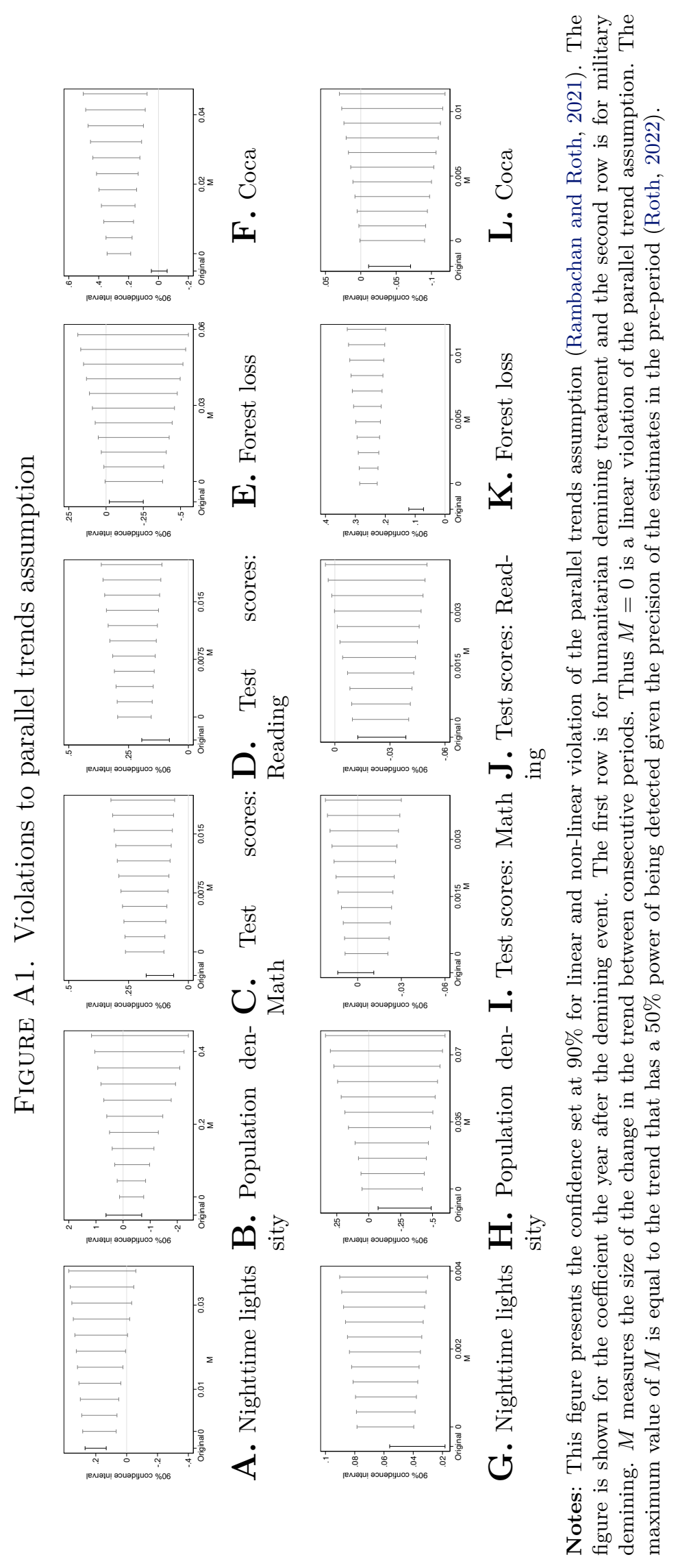


Figure A2. Events by year of occurrence

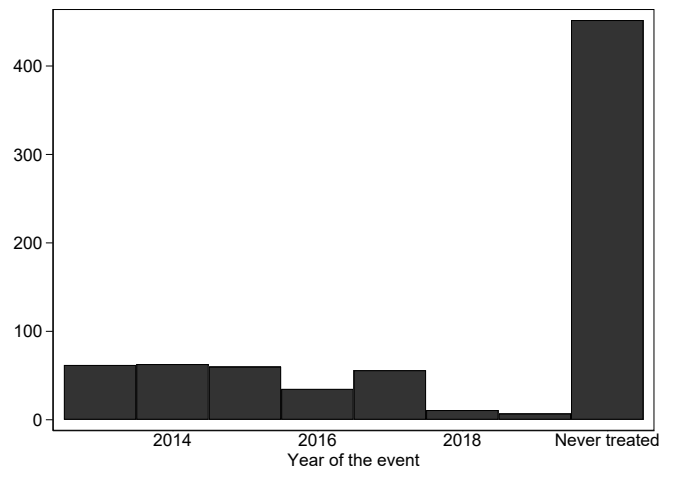

A. Humanitarian demining during peace

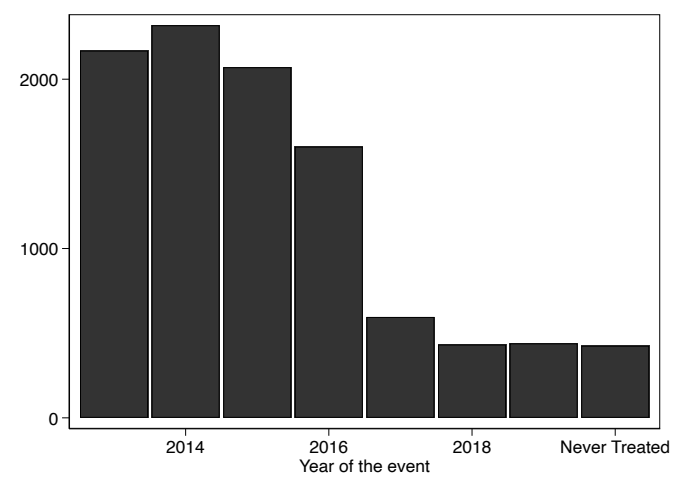

B. Military demining during peace

Notes: This figure presents the number of treated units by cohort and the never treated units for the three treatments, humanitarian demining during peace (panel A) and military demining during peace (panel B).

FiguRE A3. Differential characteristics by road connectivity

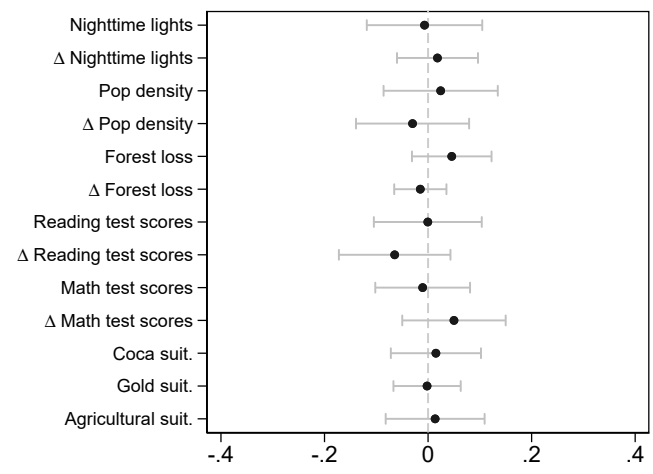

A. Any Road

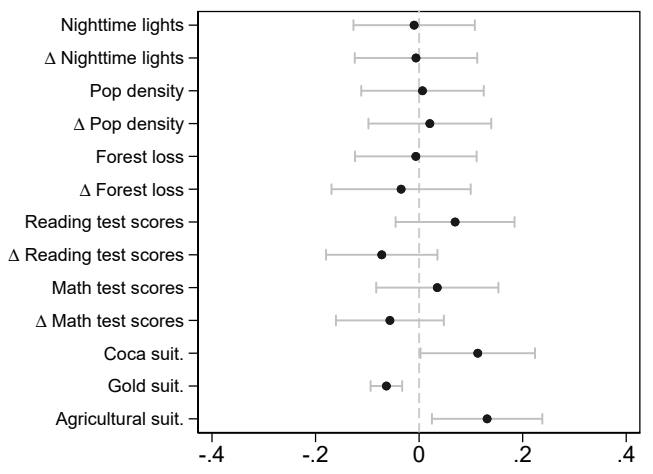

B. Road's Density

Notes: This figure presents the standardized differences by road connectivity. The sample is limited to municipalities that experienced any humanitarian demining since 2013. In Panel A, we present point estimates and confidence intervals for a regression of the indicator of any paved or unpaved road that crosses as close as $1 \mathrm{~km}$ the deminied area in the municipality. In Panel B, we do the same but in this case, the dependent variable is an indicator for the higher area of roads, measured by the length of the road that crosses as close as $1 \mathrm{~km}$ from the demined area in the municipality. Variables with a $\Delta$ are the first differences of the variable taking an average of two years before 2013 . 
Figure A4. Distribution of treatment effects based on samples with higher overlap based on different pscores

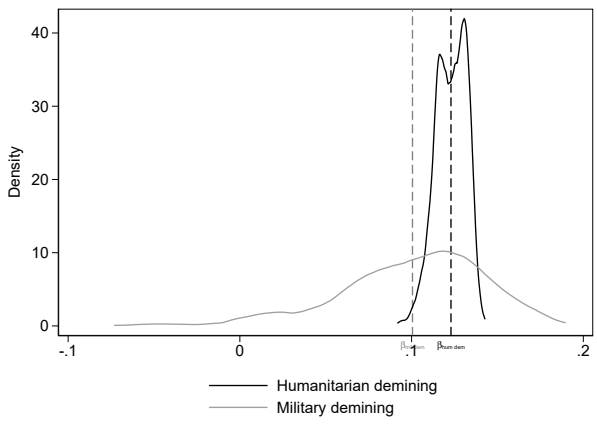

A. Nighttime lights

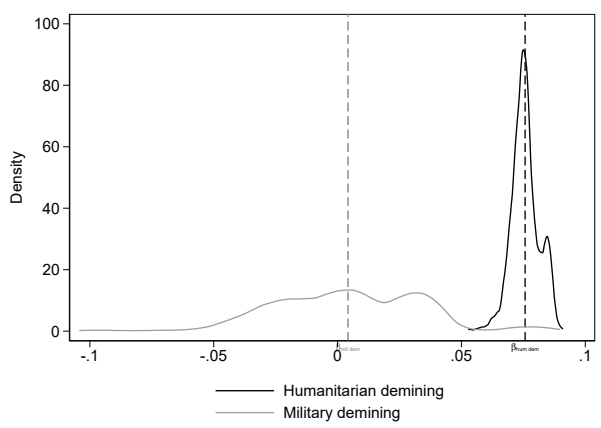

C. Ratio Approved Math

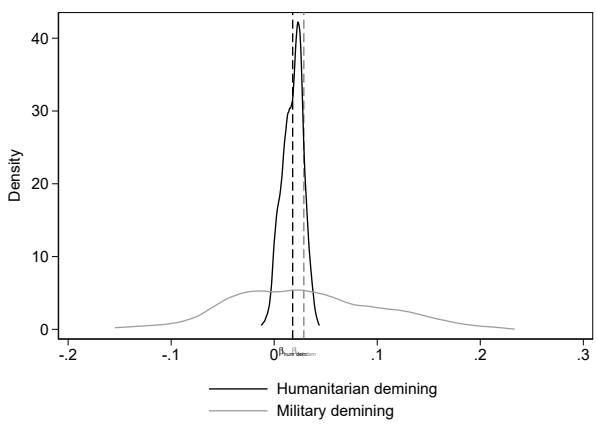

E. Forest loss

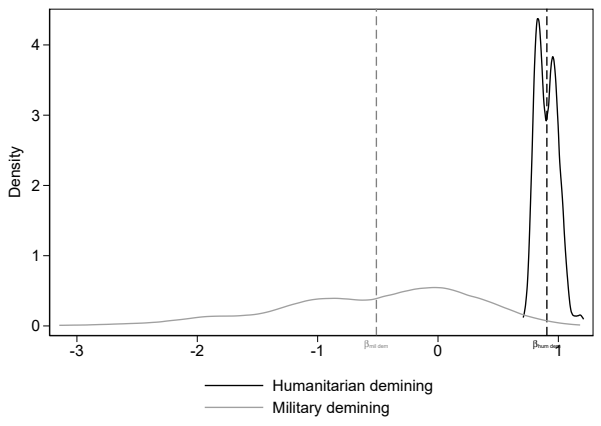

B. Population density

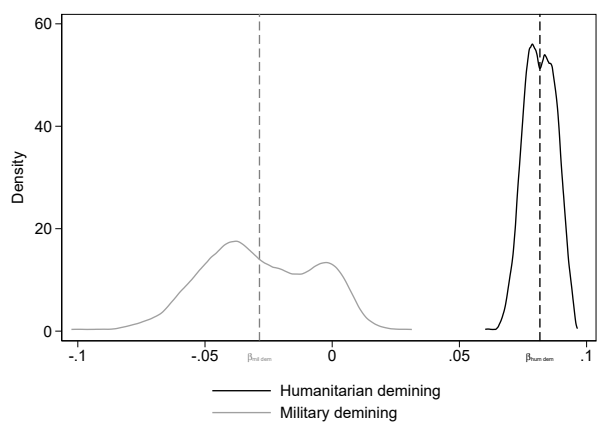

D. Ratio Approved Language

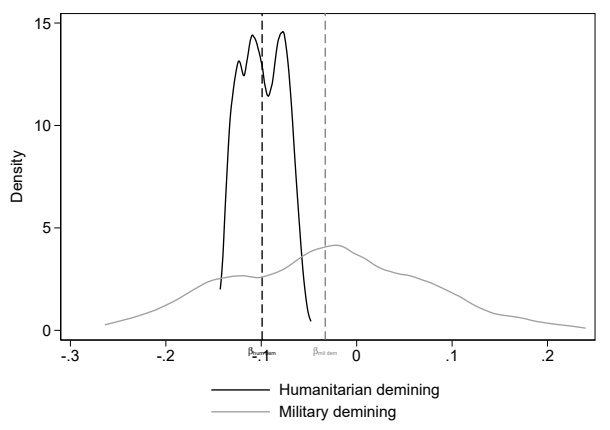

F. Coca

Notes: This figure presents the distribution of placebo ATT following Callaway and Sant'Anna (2021) for the treatments of humanitarian demining and military demining during peace. The set of controls include not yet treated and never treated. The outcomes were computed using a radius of $5 \mathrm{~km}$ around the demining. For each iteration, we restricted the sample to the optimal selection rule from Crump et al. (2009) over different propensity score definitions on the probability of being a humanitarian demining. In each propensity score definition, we selected the covariates from the set of all possible combinations of variables, and we started with at least three covariates in each group. The covariates used to predict the probability were selected from the following group of variables; a poverty index, the logarithm of population, a rurality index, the distance to the closest department's capital, the distance to the country's capital, the distance to the closest national park, a coca suitability index, elevation, precipitation, and temperature. 
Figure A5. Humanitarian demining and education

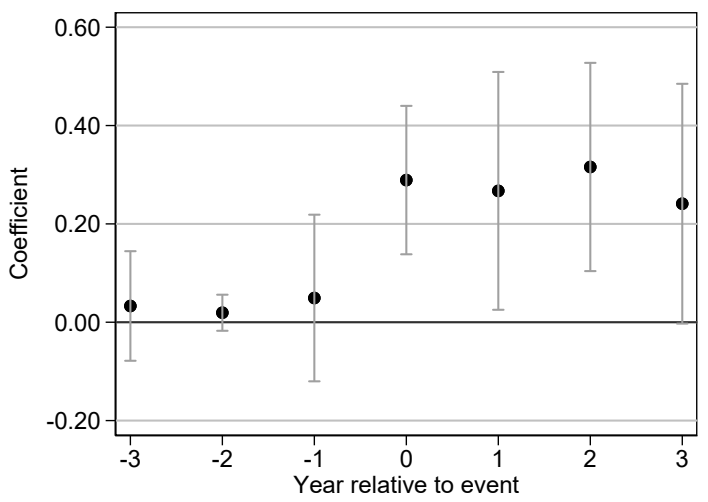

A. Enrollment - All

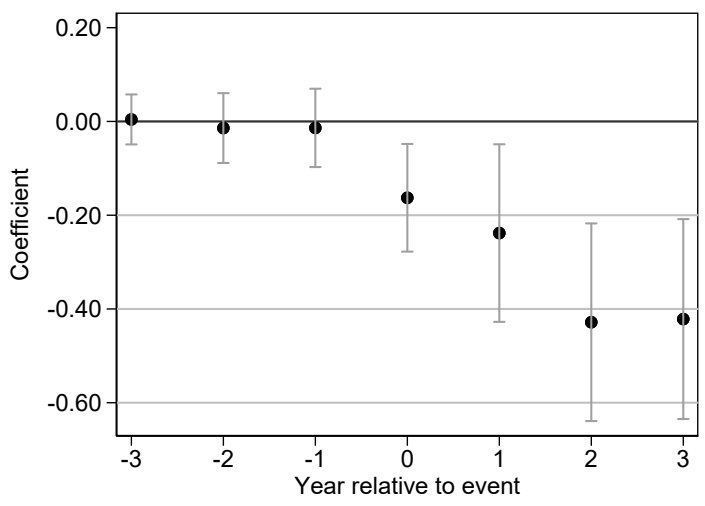

C. Ratio Student Teacher

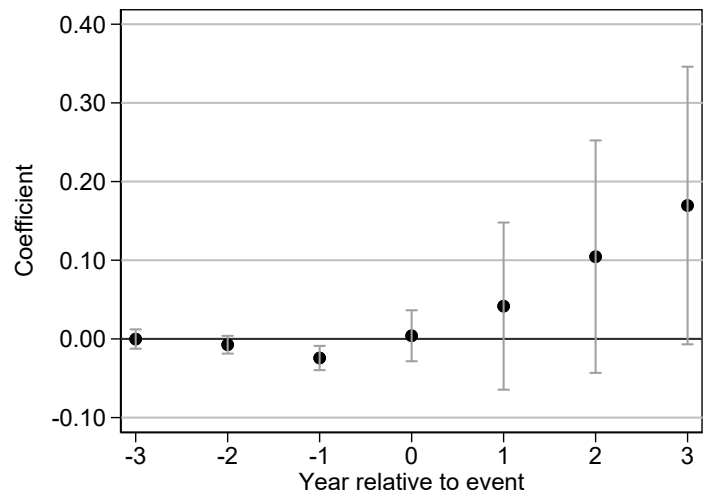

B. Share Test Taker

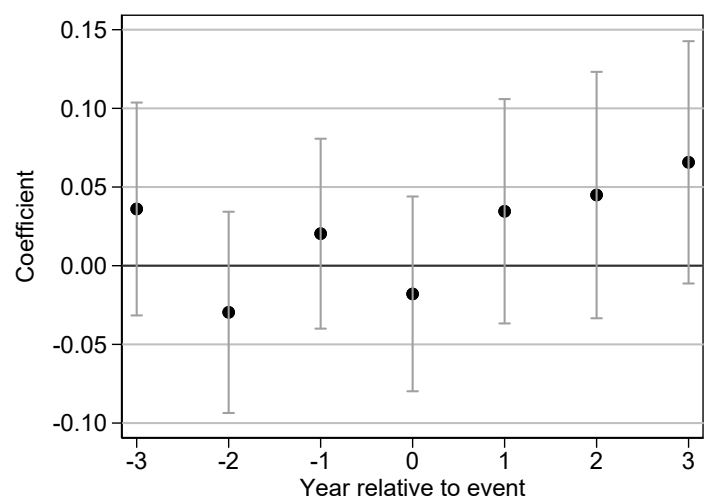

D. School Entry

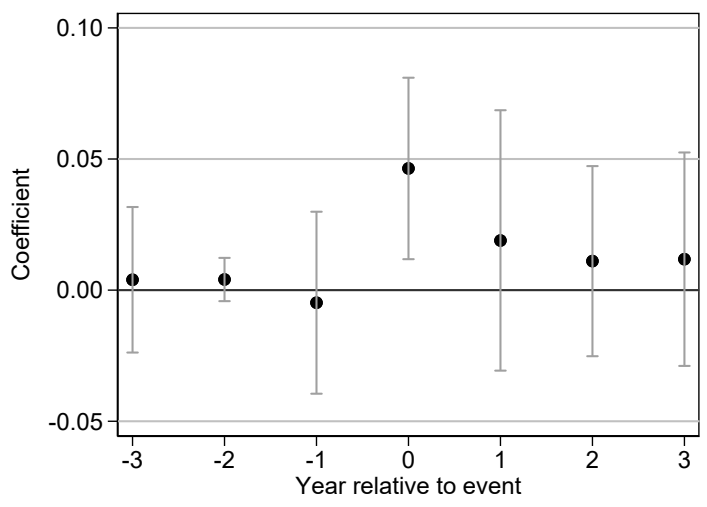

E. Share Approved

Notes: This figure presents the event study coefficients following Callaway and Sant'Anna (2021) for the treatment of demining during peace. We present the point estimates as well as the $95 \%$ confidence interval. Standard errors clustered at the event level. The outcomes were computed using a radius of $5 \mathrm{~km}$ around the demining. 
Figure A6. Demining fires, and illegal mining

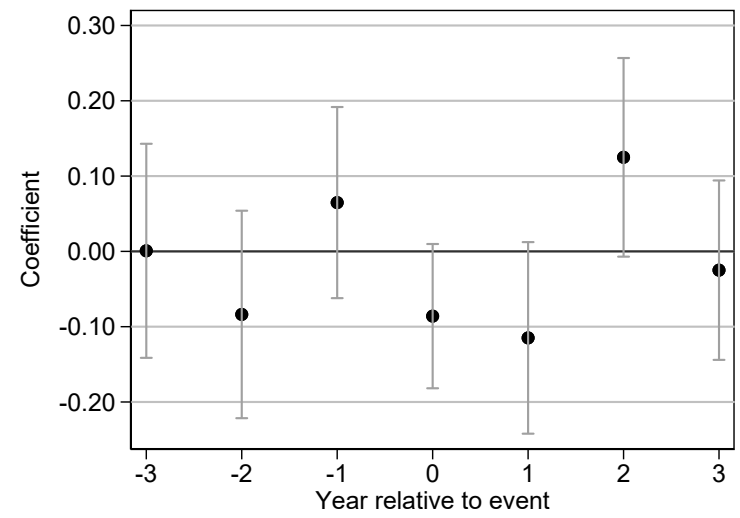

A. Humanitarian demining: Fires

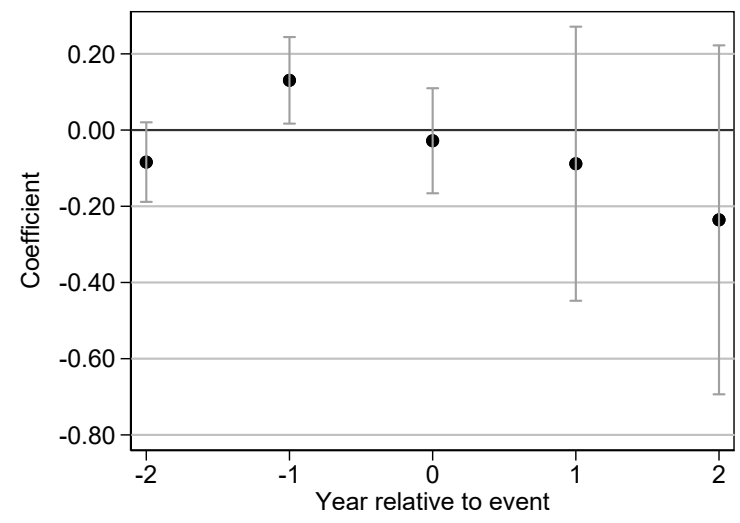

C. Humanitarian demining: Area

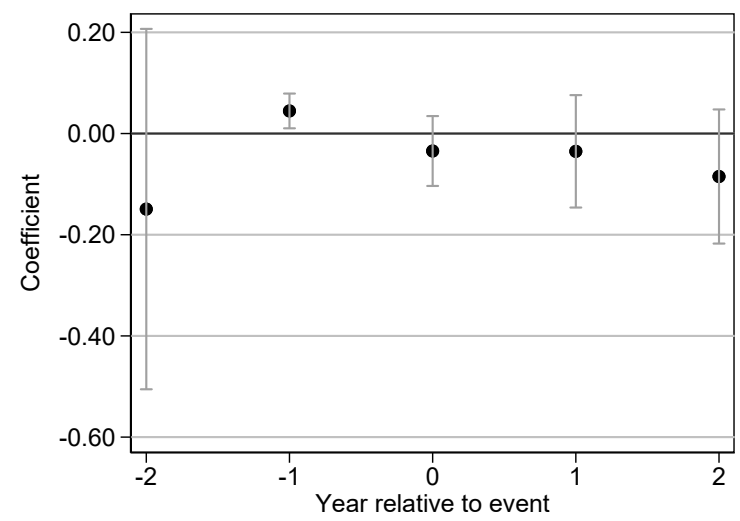

E. Humanitarian demining: Any

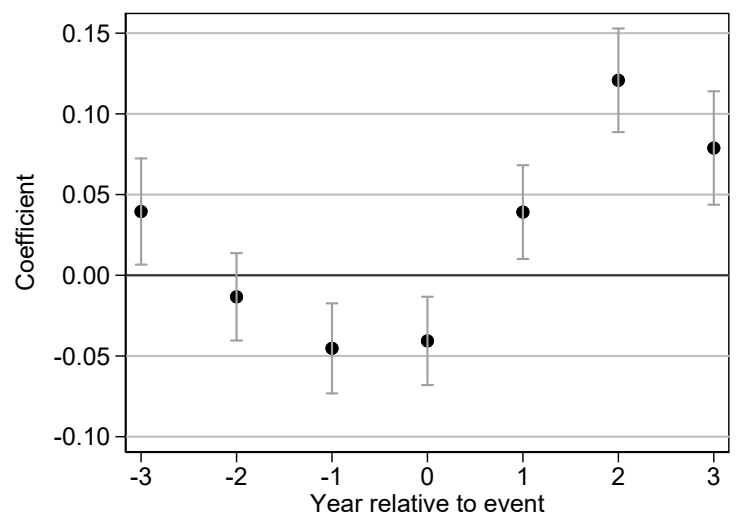

B. Military demining: Fires

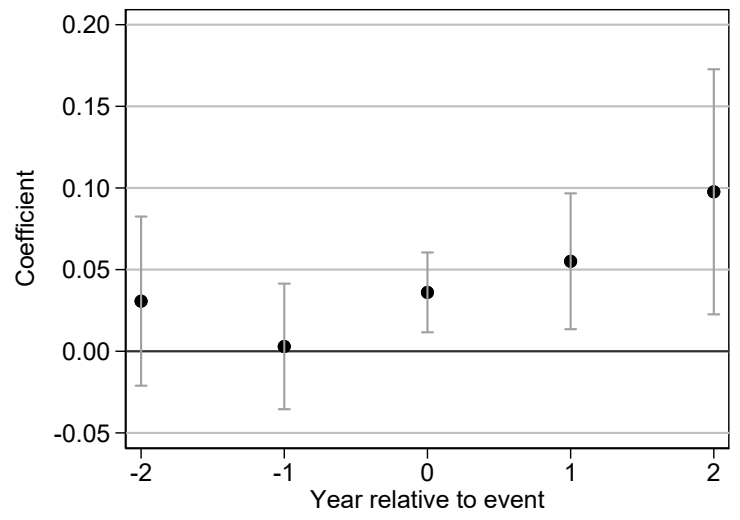

D. Military demining: Area

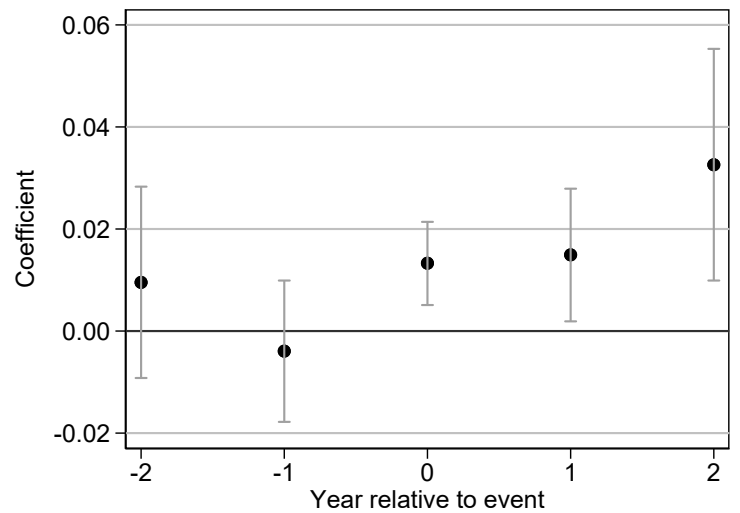

F. Military demining: Any

Notes: This figure presents the event study coefficients following Callaway and Sant'Anna (2021) for the two demining treatments. We present the point estimates as well as the $95 \%$ confidence interval. Standard errors clustered at the event level. The outcomes were computed using a radius of $5 \mathrm{~km}$ around the demining. 


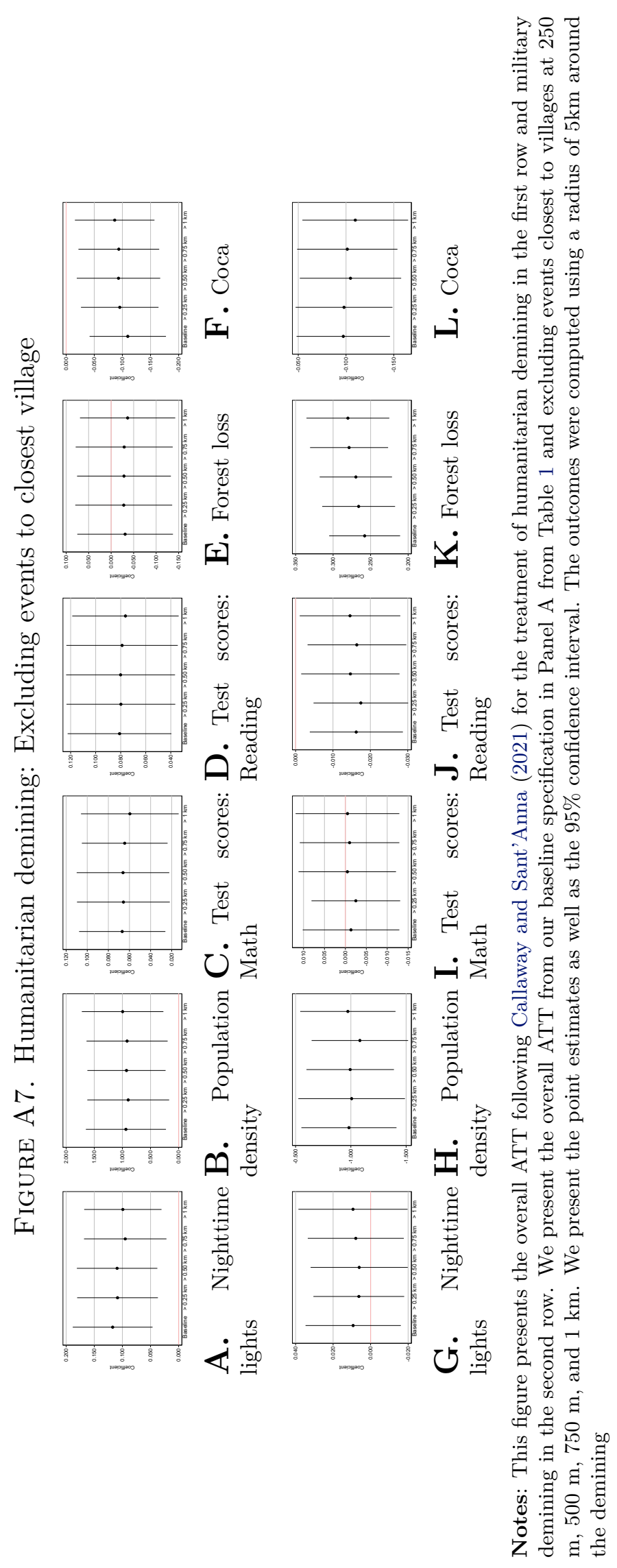


TABle A1. Two-way fixed effects decomposition and weights

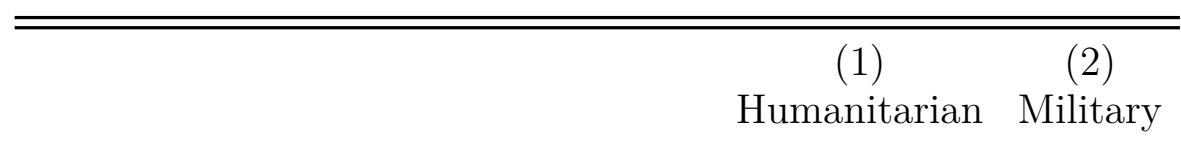

\section{Panel A: Bacon decomposition}

$\begin{array}{lll}\text { Treated }(\mathrm{T}) \text { vs Never treated (C) } & 0.847 & 0.267 \\ \text { Early treated (T) vs Late treated (C) } & 0.100 & 0.461 \\ \text { Late treated (T) vs Early treated (C) } & 0.053 & 0.272\end{array}$

\section{Panel B: Negative weights}

$\begin{array}{lll}\text { Share of negative weights } & 0.000 & 0.272 \\ \text { Share of sum of negative weights } & 0.000 & 0.166\end{array}$

Notes: This table presents the decomposition of the two-way fixed effects model from equation (4.1) for humanitarian demining (column 1) and military demining (column 2). In panel A, we present the Goodman-Bacon (2021) decomposition, $(\mathrm{T})$ stands for treated units and (C) for comparison units. In panel B, we present the share of negative weights and their relevance following De Chaisemartin and d'Haultfoeuille (2020).

TABLE A2. Robustness to "group" overall ATT

\begin{tabular}{|c|c|c|c|c|c|c|}
\hline & \multirow[t]{2}{*}{ (1) } & \multirow[t]{2}{*}{$(2)$} & $(3)$ & (4) & \multirow[t]{2}{*}{$(5)$} & \multirow[t]{2}{*}{$(6)$} \\
\hline & & & \multicolumn{2}{|c|}{ Test scores: } & & \\
\hline Dep. variable: & $\begin{array}{l}\text { Nighttime } \\
\text { Lights }\end{array}$ & $\begin{array}{c}\text { Population } \\
\text { density }\end{array}$ & Math & Reading & $\begin{array}{c}\text { Forest } \\
\text { loss }\end{array}$ & Coca \\
\hline \multicolumn{7}{|c|}{ Panel A: Humanitarian demining } \\
\hline Post demining & $\begin{array}{c}0.077^{* * * *} \\
(0.031)\end{array}$ & $\begin{array}{c}0.759^{* *} \\
(0.295)\end{array}$ & $\begin{array}{c}0.051^{* *} \\
(0.020)\end{array}$ & $\begin{array}{c}0.062^{* * *} \\
(0.021)\end{array}$ & $\begin{array}{c}-0.033 \\
(0.059)\end{array}$ & $\begin{array}{c}-0.073^{* *} \\
(0.035)\end{array}$ \\
\hline \multicolumn{7}{|c|}{ Panel B: Military demining } \\
\hline Post demining & $\begin{array}{c}0.017 \\
(0.013)\end{array}$ & $\begin{array}{c}-0.977^{* * *} \\
(0.205)\end{array}$ & $\begin{array}{c}-0.003 \\
(0.006)\end{array}$ & $\begin{array}{c}-0.018^{* * *} \\
(0.006)\end{array}$ & $\begin{array}{c}0.269^{* * *} \\
(0.025)\end{array}$ & $\begin{array}{c}-0.107^{* * *} \\
(0.023)\end{array}$ \\
\hline Observations (Panel A) & 5983 & 7460 & 6960 & 6960 & 7460 & 7460 \\
\hline Observations (Panel B) & 90504 & 100560 & 69340 & 69370 & 100560 & 100560 \\
\hline Treated (Panel A) & 291 & 294 & 283 & 283 & 294 & 294 \\
\hline Treated (Panel B) & 9630 & 9630 & 6641 & 6641 & 9630 & 9630 \\
\hline Never treated (Panel A) & 449 & 452 & 413 & 413 & 452 & 452 \\
\hline Never treated (Panel B) & 426 & 426 & 293 & 296 & 426 & 426 \\
\hline Average dep var (Panel A) & 1.675 & 34.407 & 0.207 & 0.222 & 3.290 & 0.636 \\
\hline Average dep var (Panel B) & 0.973 & 33.381 & 0.149 & 0.168 & 3.721 & 2.392 \\
\hline
\end{tabular}

Notes: This table presents the overall ATT following Callaway and Sant'Anna (2021). Panel A presents the results for humanitarian demining and panel B for military demining. Post demining is the weighted average across cohorts of the cohort average treatment effects with weights proportional to the cohort size. The set of controls include not yet treated and never treated. The outcomes were computed using a radius of $5 \mathrm{~km}$ around the demining. Panel Bootstrap standard errors clustered at the event level. * is significant at the $10 \%$ level, $* *$ is significant at the $5 \%$ level, $* * *$ is significant at the $1 \%$ level. 
TABle A3. Robustness to different level clustered standard errors

\begin{tabular}{|c|c|c|c|c|c|c|}
\hline \multirow{2}{*}{\multicolumn{2}{|c|}{ (1) }} & \multirow[t]{2}{*}{$(2)$} & $(3)$ & $(4)$ & \multirow[t]{2}{*}{$(5)$} & \multirow[t]{2}{*}{ (6) } \\
\hline & & & \multicolumn{2}{|c|}{ Test scores: } & & \\
\hline Dep. variable: & $\begin{array}{l}\text { Nighttime } \\
\text { Lights }\end{array}$ & $\begin{array}{l}\text { Population } \\
\text { density }\end{array}$ & Math & Reading & $\begin{array}{l}\text { Forest } \\
\text { loss }\end{array}$ & Coca \\
\hline \multicolumn{7}{|l|}{$\begin{array}{c}\text { Humanitarian demining } \\
\text { Panel A: Vereda level }\end{array}$} \\
\hline Post demining & $\begin{array}{l}0.117^{*} \\
(0.060)\end{array}$ & $\begin{array}{l}0.938^{*} \\
(0.539)\end{array}$ & $\begin{array}{c}0.067^{* *} \\
(0.026)\end{array}$ & $\begin{array}{c}0.081^{* * *} \\
(0.028)\end{array}$ & $\begin{array}{l}-0.031 \\
(0.080)\end{array}$ & $\begin{array}{c}-0.110^{* *} \\
(0.047)\end{array}$ \\
\hline \multicolumn{7}{|l|}{ Panel B: Grids of $15 \times 15 \mathrm{Km}$} \\
\hline Post demining & $\begin{array}{l}0.117^{*} \\
(0.064)\end{array}$ & $\begin{array}{c}0.938 \\
(0.663)\end{array}$ & $\begin{array}{l}0.067^{*} \\
(0.038)\end{array}$ & $\begin{array}{c}0.081^{* *} \\
(0.039)\end{array}$ & $\begin{array}{l}-0.031 \\
(0.093)\end{array}$ & $\begin{array}{l}-0.110^{*} \\
(0.063)\end{array}$ \\
\hline \multicolumn{7}{|l|}{$\begin{array}{l}\text { Military demining } \\
\text { Panel C: Vereda level }\end{array}$} \\
\hline Post demining & $\begin{array}{c}0.009 \\
(0.116)\end{array}$ & $\begin{array}{l}-0.983 \\
(0.655)\end{array}$ & $\begin{array}{c}0.005 \\
(0.011)\end{array}$ & $\begin{array}{l}-0.011 \\
(0.012)\end{array}$ & $\begin{array}{c}0.258 \\
(0.215)\end{array}$ & $\begin{array}{c}-0.097^{* *} \\
(0.049)\end{array}$ \\
\hline \multicolumn{7}{|l|}{ Panel D: Grids of $15 \times 15 \mathrm{Km}$} \\
\hline Post demining & $\begin{array}{c}0.009 \\
(0.064)\end{array}$ & $\begin{array}{l}-0.983 \\
(0.600)\end{array}$ & $\begin{array}{c}0.005 \\
(0.014)\end{array}$ & $\begin{array}{l}-0.011 \\
(0.016)\end{array}$ & $\begin{array}{l}0.258^{* *} \\
(0.105)\end{array}$ & $\begin{array}{l}-0.097 \\
(0.074)\end{array}$ \\
\hline Observations (Panels A \& B) & 5983 & 7460 & 6960 & 6960 & 7460 & 7460 \\
\hline Observations (Panels C \& D) & 90504 & 100560 & 69340 & 69370 & 100560 & 100560 \\
\hline Treated (Panels A \& B) & 291 & 294 & 283 & 283 & 294 & 294 \\
\hline Treated (Panels C \& D) & 9630 & 9630 & 6641 & 6641 & 9630 & 9630 \\
\hline Never treated (Panels A \& B) & 449 & 452 & 413 & 413 & 452 & 452 \\
\hline Never treated (Panels C \& D) & 426 & 426 & 293 & 296 & 426 & 426 \\
\hline Average dep var (Panels A \& B) & 1.675 & 34.407 & 0.207 & 0.222 & 3.290 & 0.636 \\
\hline Average dep var (Panels C \& D) & 0.973 & 33.381 & 0.149 & 0.168 & 3.721 & 2.392 \\
\hline
\end{tabular}

Notes: This table presents the overall ATT following Callaway and Sant'Anna (2021). Panels A and B present the results for humanitarian demining, while panels $\mathrm{C}$ and $\mathrm{D}$ for military demining. Post demining is the weighted average across cohorts of the cohort average treatment effects with weights proportional to the cohort size. The set of controls include not yet treated and never treated. The outcomes were computed using a radius of $5 \mathrm{~km}$ around the demining. Panels A and C present bootstrap standard errors clustered at the vereda level, and panels B and D present bootstrap standard errors clustered at grids of size $15 \times 15 \mathrm{Km} . *$ is significant at the $10 \%$ level, ** is significant at the $5 \%$ level, $* * *$ is significant at the $1 \%$ level. 
TABLE A4. Robustness to spatial autocorrelation

\begin{tabular}{|c|c|c|c|c|c|c|}
\hline & (1) & $(2)$ & $(3)$ & $(4)$ & $(5)$ & (6) \\
\hline & & & \multicolumn{2}{|c|}{ Test scores: } & & \\
\hline Dep. variable: & $\begin{array}{l}\text { Nighttime } \\
\text { Lights }\end{array}$ & $\begin{array}{l}\text { Population } \\
\text { density }\end{array}$ & Math & Reading & $\begin{array}{c}\text { Forest } \\
\text { loss }\end{array}$ & Coca \\
\hline \multicolumn{7}{|c|}{ Panel A: Humanitarian demining } \\
\hline Post demining & $\begin{array}{c}0.109^{* * *} \\
(0.037)\end{array}$ & $\begin{array}{c}0.930^{* * *} \\
(0.351)\end{array}$ & $\begin{array}{c}0.067^{* * * *} \\
(0.022)\end{array}$ & $\begin{array}{c}0.081^{* * *} \\
(0.021)\end{array}$ & $\begin{array}{l}-0.031 \\
(0.052)\end{array}$ & $\begin{array}{c}-0.109^{* * *} \\
(0.035)\end{array}$ \\
\hline \multicolumn{7}{|c|}{ Panel B: Military demining } \\
\hline Post demining & $\begin{array}{c}0.009 \\
(0.013)\end{array}$ & $\begin{array}{c}-0.977^{* * *} \\
(0.215)\end{array}$ & $\begin{array}{c}0.005 \\
(0.006)\end{array}$ & $\begin{array}{c}-0.011^{*} \\
(0.006)\end{array}$ & $\begin{array}{c}0.258^{* * *} \\
(0.026)\end{array}$ & $\begin{array}{c}-0.095^{* * *} \\
(0.026)\end{array}$ \\
\hline Observations (Panel A) & 5983 & 7460 & 6960 & 6960 & 7460 & 7460 \\
\hline Observations (Panel B) & 90504 & 100560 & 69340 & 69370 & 100560 & 100560 \\
\hline Treated (Panel A) & 291 & 294 & 283 & 283 & 294 & 294 \\
\hline Treated (Panel B) & 9630 & 9630 & 6641 & 6641 & 9630 & 9630 \\
\hline Never treated (Panel A) & 449 & 452 & 413 & 413 & 452 & 452 \\
\hline Never treated (Panel B) & 426 & 426 & 293 & 296 & 426 & 426 \\
\hline Average dep var (Panel A) & 1.675 & 34.407 & 0.207 & 0.222 & 3.290 & 0.636 \\
\hline Average dep var (Panel B) & 0.973 & 33.381 & 0.149 & 0.168 & 3.721 & 2.392 \\
\hline
\end{tabular}

Notes: This table presents the overall ATT following Callaway and Sant'Anna (2021). Panel A presents the results for humanitarian demining, while panel B for military demining. Post demining is the weighted average across cohorts of the cohort average treatment effects with weights proportional to the cohort size. The set of controls include not yet treated and never treated. The outcomes were computed using a radius of $5 \mathrm{~km}$ around the demining. We residualized our outcomes from Moran's I eigenvectors, which capture spatial autocorrelation among our buffers (Bauman et al., 2018). Bootstrap standard errors clustered at the event level. * is significant at the $10 \%$ level, ** is significant at the $5 \%$ level, $* * *$ is significant at the $1 \%$ level. 
TABLE A5. The effects of demining on alternative nighttime lights definitions

\begin{tabular}{|c|c|c|c|c|c|c|}
\hline \multirow{4}{*}{ Dep. variable: } & $(1)$ & $(2)$ & $(3)$ & $(4)$ & $(5)$ & (6) \\
\hline & \multicolumn{6}{|c|}{ Nighttime lights } \\
\hline & \multicolumn{3}{|c|}{ Humanitarian demining } & \multicolumn{3}{|c|}{ Military demining } \\
\hline & Levels & $\log$ & $\begin{array}{l}\text { Growth } \\
\text { rate }\end{array}$ & Levels & $\log$ & $\begin{array}{l}\text { Growth } \\
\text { rate }\end{array}$ \\
\hline Post demining & $\begin{array}{c}0.465^{* * *} \\
(0.090)\end{array}$ & $\begin{array}{c}0.093^{* * *} \\
(0.030)\end{array}$ & $\begin{array}{c}0.218^{* * *} \\
(0.073)\end{array}$ & $\begin{array}{c}0.077 \\
(0.073)\end{array}$ & $\begin{array}{c}-0.029 * * \\
(0.015)\end{array}$ & $\begin{array}{c}0.011 \\
(0.024)\end{array}$ \\
\hline Observations & 5983 & 5983 & 5385 & 49347 & 49347 & 41950 \\
\hline Treated & 291 & 291 & 289 & 8959 & 8959 & 7224 \\
\hline Never treated & 449 & 449 & 449 & 378 & 378 & 315 \\
\hline Average dep var & 3.588 & 1.303 & 0.336 & 4.558 & 1.401 & 0.416 \\
\hline
\end{tabular}

Notes: This table present overall ATT following Callaway and Sant'Anna (2021) for each demining treatment. Post demining is the weighted average of all group-time average treatment effects with weights proportional to group size. The set of controls include not yet treated and never treated. The outcomes were computed using a radius of $5 \mathrm{~km}$ around the demining. All columns present the results for the dependent variable winsorized at $1 \%$. Bootstrap standard errors clustered at the municipality level. * is significant at the $10 \%$ level, ** is significant at the $5 \%$ level, $* * *$ is significant at the $1 \%$ level.

TABLE A6. The local effects of humanitarian demining on test scores by school degree

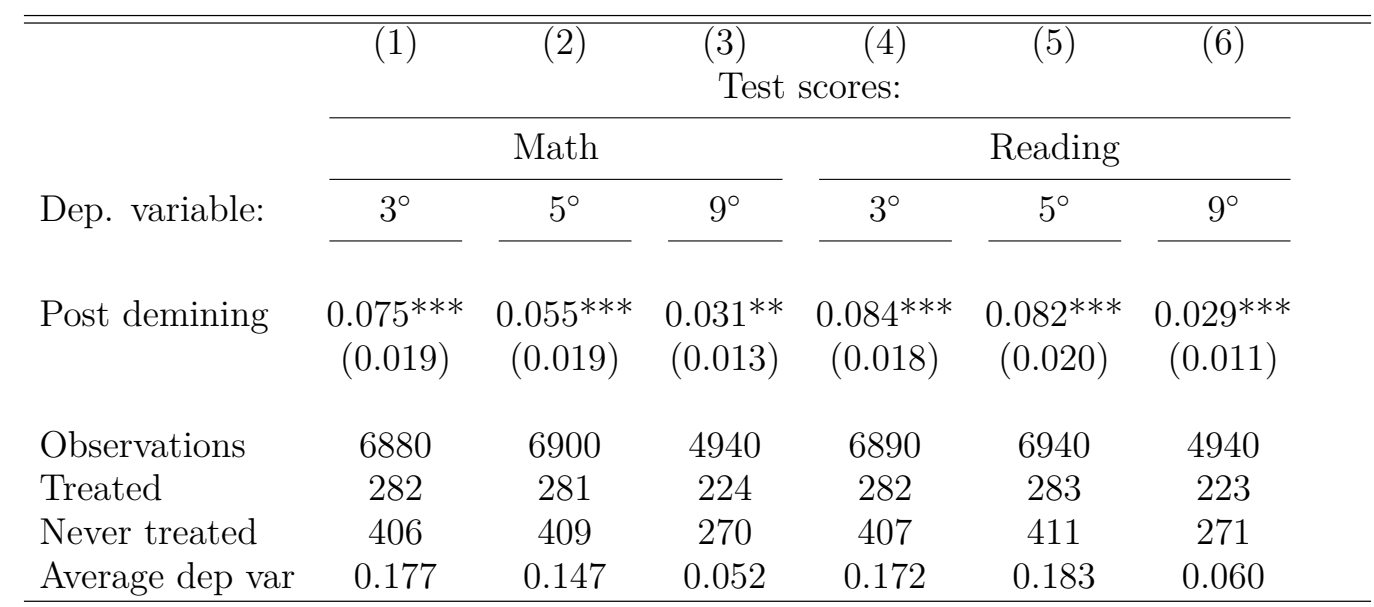

Notes: This table presents the overall ATT following Callaway and Sant'Anna (2021) for humanitarian demining during peace. Post demining is the weighted average of all group-time average treatment effects with weights proportional to group size. The set of controls include not yet treated and never treated. The outcomes were computed using a radius of $5 \mathrm{~km}$ around the demining. Bootstrap standard errors clustered at the municipality level. * is significant at the $10 \%$ level, ${ }^{* *}$ is significant at the $5 \%$ level, ${ }^{* * *}$ is significant at the $1 \%$ level. 
TABLE A7. Treatment effects based on a sample with higher overlap

\begin{tabular}{|c|c|c|c|c|c|c|}
\hline \multirow[b]{3}{*}{ Dep. variable: } & \multirow[t]{2}{*}{ (1) } & \multirow[b]{3}{*}{$\begin{array}{c}\text { Population } \\
\text { density }\end{array}$} & \multirow{2}{*}{\multicolumn{2}{|c|}{$\begin{array}{l}(3) \quad(4) \\
\text { Test scores: }\end{array}$}} & \multirow{3}{*}{$\begin{array}{c}(5) \\
\text { Forest } \\
\text { loss }\end{array}$} & \multirow[b]{3}{*}{ Coca } \\
\hline & & & & & & \\
\hline & $\begin{array}{l}\text { Nighttime } \\
\text { Lights }\end{array}$ & & Math & Reading & & \\
\hline \multicolumn{7}{|c|}{ Panel A: Humanitarian demining } \\
\hline Post demining & $\begin{array}{c}0.123^{* * *} \\
(0.038)\end{array}$ & $\begin{array}{c}1.254^{* * *} \\
(0.364)\end{array}$ & $\begin{array}{c}0.069^{* * *} \\
(0.022)\end{array}$ & $\begin{array}{c}0.073^{* * *} \\
(0.022)\end{array}$ & $\begin{array}{l}-0.006 \\
(0.057)\end{array}$ & $\begin{array}{c}-0.074^{* *} \\
(0.034)\end{array}$ \\
\hline \multicolumn{7}{|c|}{ Panel B: Military demining } \\
\hline Post demining & $\begin{array}{c}0.067^{* * * *} \\
(0.023)\end{array}$ & $\begin{array}{l}0.703^{*} \\
(0.376)\end{array}$ & $\begin{array}{l}-0.015 \\
(0.013)\end{array}$ & $\begin{array}{c}-0.026^{* *} \\
(0.013)\end{array}$ & $\begin{array}{c}-0.087^{* *} \\
(0.038)\end{array}$ & $\begin{array}{c}-0.313^{* * *} \\
(0.054)\end{array}$ \\
\hline Observations (Panel A) & 5291 & 6470 & 6170 & 6170 & 6470 & 6470 \\
\hline Observations (Panel B) & 32958 & 36620 & 25690 & 25780 & 36620 & 36620 \\
\hline Treated (Panel A) & 265 & 267 & 261 & 261 & 267 & 267 \\
\hline Treated (Panel B) & 3580 & 3580 & 2515 & 2524 & 3580 & 3580 \\
\hline Never treated (Panel A) & 377 & 380 & 356 & 356 & 380 & 380 \\
\hline Never treated (Panel B) & 82 & 82 & 54 & 54 & 82 & 82 \\
\hline Average dep var (Panel A) & 1.646 & 34.115 & 0.209 & 0.223 & 3.201 & 0.445 \\
\hline Average dep var (Panel B) & 1.076 & 39.315 & 0.175 & 0.194 & 3.078 & 1.213 \\
\hline P-value diff. & 0.207 & 0.292 & 0.001 & 0.000 & 0.237 & 0.000 \\
\hline
\end{tabular}

Notes: This table presents the overall ATT following Callaway and Sant'Anna (2021) for the treatments of humanitarian demining and military demining. Post demining is the weighted average of all group-time average treatment effects with weights proportional to group size. The set of controls include not yet treated and never treated. The outcomes were computed using a radius of $5 \mathrm{~km}$ around the demining. The sample is restricted to the optimal selection rule from Crump et al. (2009) over the propensity score, probability of being a humanitarian demining. The covariates used to predict the probability were selected following Belloni et al. (2014) machine learning algorithm, which selects the best covariates predicting humanitarian demining. The selected covariates were a poverty index, the logarithm of population, the distance to the closest department's capital, a coca suitability index, the distance to the country's capital, and the distance to the closest national park. The pool of potential covariates also included a rurality index, elevation, precipitation, and temperature. We also present the p-value that tests the difference between the coefficients of Panel A and B. Bootstrap standard errors clustered at the event level. * is significant at the $10 \%$ level, $* *$ is significant at the $5 \%$ level, $* * *$ is significant at the $1 \%$ level. 
TABlE A8. The local effects of demining intensity

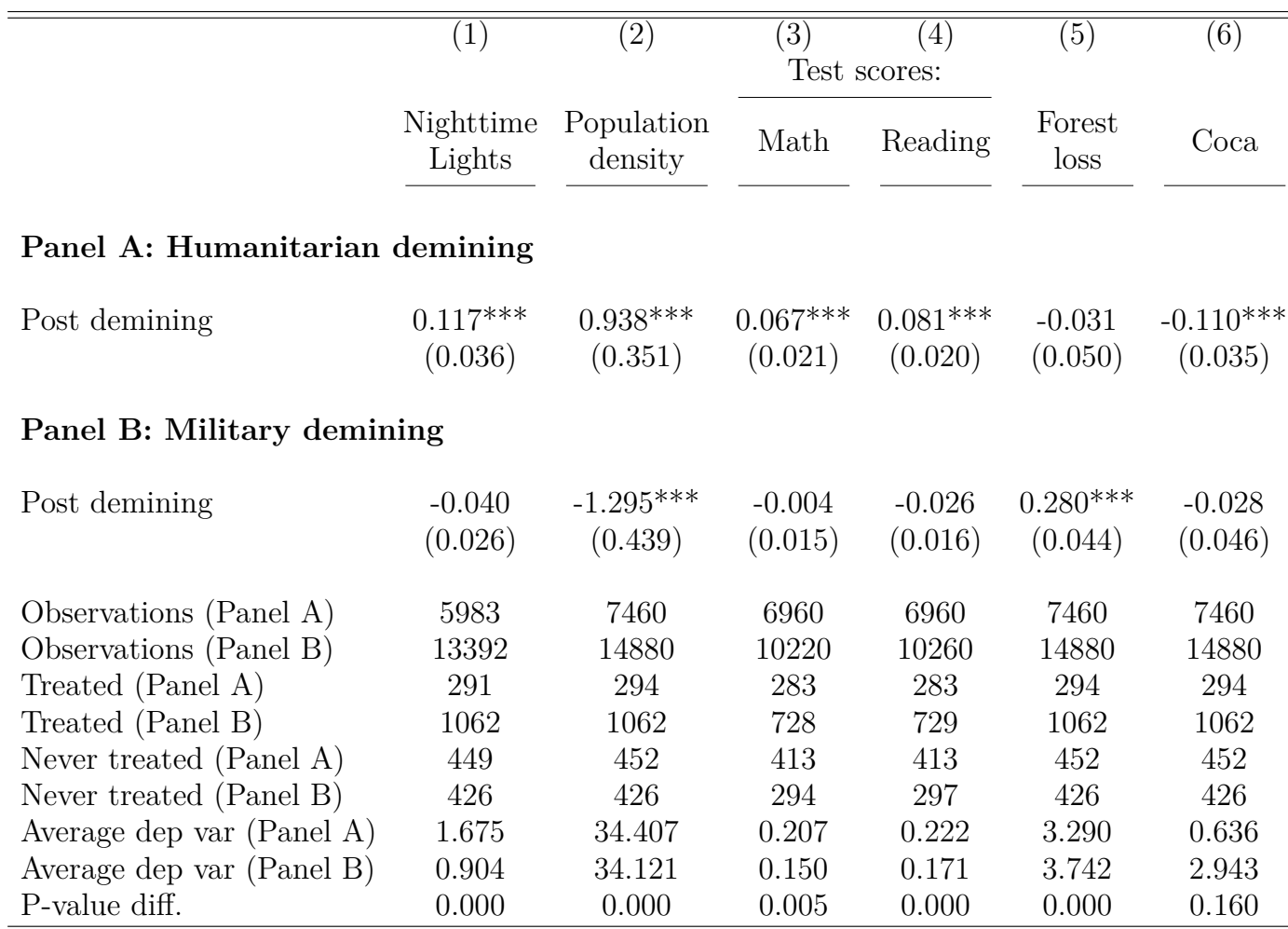

Notes: This table presents the overall ATT following Callaway and Sant'Anna (2021) for each demining treatment. Post demining is the weighted average of all group-time average treatment effects with weights proportional to group size. The set of controls include not yet treated and never treated. The outcomes were computed using a radius of $5 \mathrm{~km}$ around the demining. The humanitarian demining, as baseline, follows the same definition proposed in Table 1. For the military demining during peace and conflict treatments, we sub-sample our events to the ones with the number of destroyed landmines above the median of the humanitarian demining events. Bootstrap standard errors clustered at the event level. P-value diff. is the p-value of the test for the difference in the coefficients within the same column across panels. $*$ is significant at the $10 \%$ level, $* *$ is significant at the $5 \%$ level, $* * *$ is significant at the $1 \%$ level.

TABLE A9. Bias from hypothesized linear pre-trend

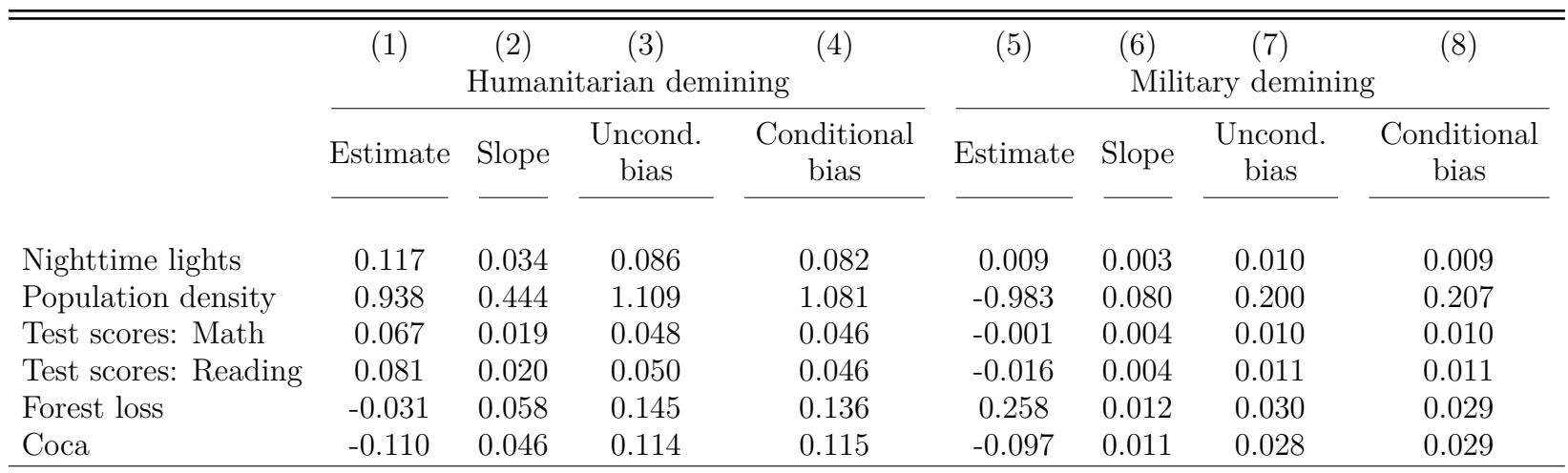

Notes: This table presents the estimated parameter from our baseline specification in Panel A from Tables 1 and 2 and the main estimates based on Roth (2022). In columns 2 and 6, we present the pre-trend that has a $50 \%$ power of being detected given the precision of the estimates in the pre-period. In columns 3 and 7 , we present the average bias suggested by this trend, while in column 4 and 8 , the bias from the adjusted pre-trend that takes into account the pre-testing bias that arises from the fact that the analysis shown is conditional on passing a pre-test. 
TABLE A10. Heterogeneous effects for educational outcomes by proximity to a school - Humanitarian demining

\begin{tabular}{|c|c|c|c|c|c|c|}
\hline \multirow{4}{*}{ Dep. variable: } & $(1)$ & $(2)$ & $(3)$ & (4) & $(5)$ & $(6)$ \\
\hline & \multicolumn{6}{|c|}{ Schools } \\
\hline & \multicolumn{3}{|c|}{ Test scores - Math } & \multicolumn{3}{|c|}{ Test scores - Spanish } \\
\hline & Close & Not close & $\begin{array}{c}\text { p-value } \\
\text { diff. }\end{array}$ & Close & Not close & $\begin{array}{c}\text { p-value } \\
\text { diff. }\end{array}$ \\
\hline Post demining & $\begin{array}{c}0.194^{* * *} \\
(0.046)\end{array}$ & $\begin{array}{c}0.105 \\
(0.086)\end{array}$ & 0.363 & $\begin{array}{c}0.221^{* * *} \\
(0.043)\end{array}$ & $\begin{array}{c}0.155^{* *} \\
(0.073)\end{array}$ & 0.436 \\
\hline Observations & 6260 & 4830 & & 6260 & 4830 & \\
\hline Treated & 213 & 70 & & 213 & 70 & \\
\hline Never treated & 413 & 413 & & 413 & 413 & \\
\hline Avg dep var (Panel A) & 0.210 & 0.201 & & 0.226 & 0.217 & \\
\hline
\end{tabular}

Notes: This table presents the overall ATT following Callaway and Sant'Anna (2021) for students' performance in math and Spanish (Panels A and B, respectively) after a humanitarian demining event. Post demining is the weighted average of all group-time average treatment effects with weights proportional to group size. The set of controls include not yet treated and never treated. The outcomes were computed using a radius of $5 \mathrm{~km}$ around the demining. In column (1), we present the results with those events that had at least one school within a 100 meters from the demined area; in column (2), those that did not have a school close by. * is significant at the $10 \%$ level, $* *$ is significant at the $5 \%$ level, $* * *$ is significant at the $1 \%$ level.

TABLE A11. The local effects of demining on illegal gold mining

\begin{tabular}{|c|c|c|c|c|c|c|}
\hline Demining: & \multicolumn{3}{|c|}{ Humanitarian } & \multicolumn{3}{|c|}{ Military } \\
\hline Dep. variable: & Fires & $\begin{array}{l}\text { Area illegal } \\
\text { gold mining }\end{array}$ & $\begin{array}{l}\text { Illegal } \\
\text { gold mining }\end{array}$ & Fires & $\begin{array}{l}\text { Area illegal } \\
\text { gold mining }\end{array}$ & $\begin{array}{l}\text { Illegal } \\
\text { gold mining }\end{array}$ \\
\hline Post demining & $\begin{array}{l}-0.048 \\
(0.049)\end{array}$ & $\begin{array}{l}-0.103 \\
(0.146)\end{array}$ & $\begin{array}{l}-0.048 \\
(0.046)\end{array}$ & $\begin{array}{c}0.033^{* *} \\
(0.014)\end{array}$ & $\begin{array}{c}0.059^{* * *} \\
(0.020)\end{array}$ & $\begin{array}{c}0.019 * * * \\
(0.006)\end{array}$ \\
\hline Observations & 7460 & 2020 & 2020 & 10560 & 11604 & 11604 \\
\hline Treated & 294 & 53 & 53 & 9630 & 2475 & 2475 \\
\hline Never treated & 452 & 452 & 452 & 426 & 426 & 426 \\
\hline Average dep var & 0.592 & 0.216 & 0.065 & 0.879 & 0.415 & 0.084 \\
\hline
\end{tabular}

Notes: This table presents the overall ATT following Callaway and Sant'Anna (2021) for fires and illegal alluvial gold mining using the humanitarian and military demining treatments. Post demining is the weighted average of all group-time average treatment effects with weights proportional to group size. The set of controls includes not yet treated and never treated. The outcomes were computed using a radius of $5 \mathrm{~km}$ around the demining. ${ }^{*}$ significant at the $10 \%$ level, $* *$ is significant at the $5 \%$ level, *** is significant at the $1 \%$ level 
TABLE A12. Heterogeneous effects for coca cultivation by substitution program

\begin{tabular}{|c|c|c|c|c|c|c|}
\hline \multirow{3}{*}{$\begin{array}{l}\text { Dep. variable: } \\
\text { Demining: }\end{array}$} & (1) & $(2)$ & $(3)$ & $(4)$ & $(5)$ & (6) \\
\hline & \multicolumn{6}{|c|}{ Coca cultivation } \\
\hline & \multicolumn{3}{|c|}{ Humanitarian } & \multicolumn{3}{|c|}{ Military } \\
\hline PNIS: & No & Yes & $\begin{array}{l}\text { p-value } \\
\text { diff. }\end{array}$ & No & Yes & $\begin{array}{c}\text { p-value } \\
\text { diff. }\end{array}$ \\
\hline Post demining & $\begin{array}{l}0.131^{*} \\
(0.068)\end{array}$ & $\begin{array}{c}-0.511^{* *} \\
(0.257)\end{array}$ & 0.016 & $\begin{array}{l}-0.047 \\
(0.046)\end{array}$ & $\begin{array}{c}-0.149 * * * \\
(0.037)\end{array}$ & 0.084 \\
\hline Observations & 4650 & 580 & & 7860 & 11060 & \\
\hline Treated & 60 & 14 & & 639 & 828 & \\
\hline Never treated & 405 & 44 & & 147 & 278 & \\
\hline Average dep var & 0.766 & 1.213 & & 2.212 & 5.089 & \\
\hline
\end{tabular}

Notes: This table presents the overall ATT following Callaway and Sant'Anna (2021) for coca cultivation using for both demining treatments. Post demining is the weighted average of all group-time average treatment effects with weights proportional to group size. The set of controls include not yet treated and never treated. The outcomes were computed using a radius of $5 \mathrm{~km}$ around the demining. For each type of treatment, we divide the treated and never treated into events in municipalities without and within the PNIS program. * is significant at the $10 \%$ level, $* *$ is significant at the $5 \%$ level, $* * *$ is significant at the $1 \%$ level.

TABLE A13. Summary statistics

\begin{tabular}{|c|c|c|c|c|c|}
\hline & $\begin{array}{c}(1) \\
\text { Average }\end{array}$ & $\begin{array}{c}(2) \\
\text { Standard } \\
\text { deviation }\end{array}$ & $\begin{array}{c}(3) \\
90 t h \\
\text { percentile }\end{array}$ & $\begin{array}{c}(4) \\
50 t h \\
\text { percentile }\end{array}$ & $\begin{array}{c}(5) \\
10 t h \\
\text { percentile }\end{array}$ \\
\hline \multicolumn{6}{|c|}{ Panel A: Humanitarian demining } \\
\hline Nighttime lights & 1.675 & 0.917 & 2.632 & 1.932 & 0.255 \\
\hline Population density & 34.407 & 30.752 & 66.871 & 26.092 & 7.839 \\
\hline Test scores: Math & 0.191 & 0.35 & 0.861 & 0 & 0 \\
\hline Test scores: Reading & 0.205 & 0.374 & 0.927 & 0 & 0 \\
\hline Forest loss & 3.29 & 1.305 & 4.928 & 3.38 & 1.473 \\
\hline Coca hts & 0.636 & 1.488 & 2.809 & 0 & 0 \\
\hline N Schools & 10.138 & 7.809 & 19 & 9 & 1 \\
\hline
\end{tabular}

\section{Panel B: Military demining}

\begin{tabular}{lccccc} 
Nighttime lights & 0.973 & 1.156 & 2.611 & 0.196 & 0 \\
Population density & 33.381 & 56.452 & 76.459 & 14.362 & 2.332 \\
Test scores: Math & 0.103 & 0.266 & 0.618 & 0 & 0 \\
Test scores: Reading & 0.116 & 0.292 & 0.75 & 0 & 0 \\
Forest loss & 3.721 & 1.521 & 5.48 & 3.963 & 1.443 \\
Coca hts & 2.392 & 2.636 & 6.369 & 1.346 & 0 \\
N Schools & 8.084 & 12.688 & 18 & 5 & 1 \\
\hline
\end{tabular}

Notes: This table presents summary statistics for our main variables of interest. The outcomes in panels A and B were computed using a radius of $5 \mathrm{~km}$ around the demining event. 
TABle A14. Robustness to other estimation methods: Humanitarian demining

\begin{tabular}{|c|c|c|c|c|c|c|}
\hline \multirow[b]{3}{*}{ Dep. variable: } & \multirow[t]{2}{*}{$(1)$} & \multirow[t]{2}{*}{$(2)$} & \multirow{2}{*}{\multicolumn{2}{|c|}{$\begin{array}{l}(3) \\
\text { Test scores: }\end{array}$}} & \multirow{3}{*}{$\begin{array}{c}(5) \\
\text { Forest } \\
\text { loss }\end{array}$} & \multirow[b]{3}{*}{ Coca } \\
\hline & & & & & & \\
\hline & $\begin{array}{l}\text { Nighttime } \\
\text { Lights }\end{array}$ & $\begin{array}{c}\text { Population } \\
\text { density }\end{array}$ & Math & Reading & & \\
\hline \multicolumn{7}{|c|}{ Panel A: Borusyak et al. (2021) } \\
\hline Post demining & $\begin{array}{c}0.081^{* *} \\
(0.033)\end{array}$ & $\begin{array}{c}0.203 \\
(0.456)\end{array}$ & $\begin{array}{c}0.042^{* * *} \\
(0.015)\end{array}$ & $\begin{array}{c}0.041^{* * *} \\
(0.016)\end{array}$ & $\begin{array}{c}0.108 * * \\
(0.048)\end{array}$ & $\begin{array}{c}-0.119 * * * \\
(0.037)\end{array}$ \\
\hline \multicolumn{7}{|c|}{ Panel B: De Chaisemartin and d'Haultfoeuille (2020) } \\
\hline Post demining & $\begin{array}{c}0.080^{* * * *} \\
(0.028)\end{array}$ & $\begin{array}{c}0.528^{* *} \\
(0.214)\end{array}$ & $\begin{array}{c}0.061^{* * *} \\
(0.023)\end{array}$ & $\begin{array}{c}0.071^{* * *} \\
(0.020)\end{array}$ & $\begin{array}{c}0.002 \\
(0.042)\end{array}$ & $\begin{array}{c}-0.084^{* * *} \\
(0.024)\end{array}$ \\
\hline \multicolumn{7}{|c|}{ Panel C: Wooldridge (2021) } \\
\hline Post demining & $\begin{array}{c}0.074^{* *} \\
(0.033)\end{array}$ & $\begin{array}{c}0.202 \\
(0.457)\end{array}$ & $\begin{array}{c}0.042^{* * *} \\
(0.015)\end{array}$ & $\begin{array}{l}041^{* * *} \\
(0.016)\end{array}$ & $\begin{array}{c}0.108^{* *} \\
(0.049)\end{array}$ & $\begin{array}{c}-0.119^{* * *} \\
(0.037)\end{array}$ \\
\hline Observations & 5983 & 7460 & 6960 & 6960 & 7460 & 7460 \\
\hline Treated & 291 & 294 & 283 & 283 & 294 & 294 \\
\hline Never treated & 449 & 452 & 413 & 413 & 452 & 452 \\
\hline Average dep var & 1.675 & 34.407 & 0.207 & 0.222 & 3.290 & 0.636 \\
\hline
\end{tabular}

Notes: This table presents the overall ATT using two different models for the treatment of humanitarian demining during peace. The outcomes were computed using a radius of $5 \mathrm{~km}$ around the demining. In Panel A, we present the imputation method suggested by Borusyak et al. (2021). We estimate the model for the window of three year around the event. In Panel B, we present the model suggested by De Chaisemartin and d'Haultfoeuille (2020) computing the ATT for the three years after the treatment. In Panel C, we present the ATT suggested by Wooldridge (2021) where the estimated coefficient is a weighted average of group-year dummies after treatment. Standard errors are clustered at the event level. * is significant at the $10 \%$ level, $* *$ is significant at the $5 \%$ level, *** is significant at the $1 \%$ level. 
TABLE A15. Robustness to other estimation methods: Military demining

\begin{tabular}{|c|c|c|c|c|c|c|}
\hline \multirow[b]{3}{*}{ Dep. variable: } & \multirow[t]{2}{*}{$(1)$} & \multirow[t]{2}{*}{$(2)$} & \multirow{2}{*}{\multicolumn{2}{|c|}{$\begin{array}{l}(3) \quad(4) \\
\text { Test scores: }\end{array}$}} & \multirow{3}{*}{$\begin{array}{c}(5) \\
\text { Forest } \\
\text { loss }\end{array}$} & \multirow[b]{3}{*}{ Coca } \\
\hline & & & & & & \\
\hline & $\begin{array}{l}\text { Nighttime } \\
\text { Lights }\end{array}$ & $\begin{array}{c}\text { Population } \\
\text { density }\end{array}$ & Math & Reading & & \\
\hline \multicolumn{7}{|c|}{ Panel A: Borusyak et al. (2021) } \\
\hline Post demining & $\begin{array}{c}0.039 * * * \\
(0.015)\end{array}$ & $\begin{array}{c}-1.524^{* * *} \\
(0.253)\end{array}$ & $\begin{array}{l}0.010^{*} \\
(0.006)\end{array}$ & $\begin{array}{l}-0.004 \\
(0.006)\end{array}$ & $\begin{array}{c}0.097^{* * *} \\
(0.018)\end{array}$ & $\begin{array}{c}-0.153^{* * *} \\
(0.028)\end{array}$ \\
\hline \multicolumn{7}{|c|}{ Panel B: De Chaisemartin and d'Haultfoeuille (2020) } \\
\hline Post demining & $\begin{array}{c}0.030^{* * *} \\
(0.011)\end{array}$ & $\begin{array}{c}-0.719^{* * *} \\
(0.155)\end{array}$ & $\begin{array}{l}-0.002 \\
(0.004)\end{array}$ & $\begin{array}{c}-0.019^{* * *} \\
(0.005)\end{array}$ & $\begin{array}{c}0.145^{* * *} \\
(0.016)\end{array}$ & $\begin{array}{c}-0.090^{* * *} \\
(0.022)\end{array}$ \\
\hline \multicolumn{7}{|c|}{ Panel C: Wooldridge (2021) } \\
\hline Post demining & $\begin{array}{c}0.039 * * \\
(0.015)\end{array}$ & $\begin{array}{c}-1.524^{* * * *} \\
(0.253)\end{array}$ & $\begin{array}{l}0.010^{*} \\
(0.006)\end{array}$ & $\begin{array}{l}-0.004 \\
(0.006)\end{array}$ & $\begin{array}{c}0.096^{* * *} \\
(0.018)\end{array}$ & $\begin{array}{c}-0.153^{* * *} \\
(0.028)\end{array}$ \\
\hline Observations & 90504 & 100560 & 69340 & 69340 & 100560 & 100560 \\
\hline Treated & 9630 & 9630 & 6641 & 6641 & 9630 & 9630 \\
\hline Never treated & 426 & 426 & 293 & 296 & 426 & 426 \\
\hline Average dep var & 0.973 & 33.381 & 0.149 & 0.168 & 3.721 & 2.392 \\
\hline
\end{tabular}

Notes: This table presents the overall ATT using two different models for the treatment of military demining during peace. The outcomes were computed using a radius of $5 \mathrm{~km}$ around the demining. In Panel A, we present the imputation method suggested by Borusyak et al. (2021). We estimate the model for the window of three year around the event. In Panel B, we present the model suggested by De Chaisemartin and d'Haultfoeuille (2020) computing the ATT for the three years after the treatment. In Panel C, we present the ATT suggested by Wooldridge (2021) where the estimated coefficient is a weighted average of group-year dummies after treatment. Standard errors are clustered at the event level. Standard errors are clustered at the event level. * is significant at the $10 \%$ level, ** is significant at the $5 \%$ level, $* * *$ is significant at the $1 \%$ level. 
TABLE A16. Spillover effects of humanitarian demining: Covariates

\begin{tabular}{|c|c|c|c|c|c|c|}
\hline & (1) & $(2)$ & $(3)$ & (4) & $(5)$ & (6) \\
\hline & & & Test & scores: & & \\
\hline Dep. variable: & $\begin{array}{l}\text { Nighttime } \\
\text { Lights }\end{array}$ & $\begin{array}{c}\text { Population } \\
\text { density }\end{array}$ & Math & Reading & $\begin{array}{c}\text { Forest } \\
\text { loss }\end{array}$ & Coca \\
\hline Panel A: Buffe & of $3 \mathrm{~km}$ & & & & & \\
\hline Post demining & $\begin{array}{c}0.093^{* *} \\
(0.047)\end{array}$ & $\begin{array}{c}1.053^{* * *} \\
(0.375)\end{array}$ & $\begin{array}{c}0.034 \\
(0.026)\end{array}$ & $\begin{array}{c}0.062^{* *} \\
(0.027)\end{array}$ & $\begin{array}{l}-0.094 \\
(0.066)\end{array}$ & $\begin{array}{c}-0.061^{* * *} \\
(0.024)\end{array}$ \\
\hline Panel B: Buffe & of $5 \mathrm{~km}$ & & & & & \\
\hline Post demining & $\begin{array}{c}0.114^{* * *} \\
(0.044)\end{array}$ & $\begin{array}{c}1.019^{* *} \\
(0.425)\end{array}$ & $\begin{array}{l}0.047^{*} \\
(0.027)\end{array}$ & $\begin{array}{c}0.072^{* * * *} \\
(0.026)\end{array}$ & $\begin{array}{l}-0.061 \\
(0.068)\end{array}$ & $\begin{array}{c}-0.069^{* * *} \\
(0.026)\end{array}$ \\
\hline Panel C: Buffe & of $7 \mathrm{~km}$ & & & & & \\
\hline Post demining & $\begin{array}{c}0.115^{* *} \\
(0.047)\end{array}$ & $\begin{array}{c}0.938^{* *} \\
(0.411)\end{array}$ & $\begin{array}{c}0.058^{* *} \\
(0.028)\end{array}$ & $\begin{array}{c}0.080^{* * * *} \\
(0.027)\end{array}$ & $\begin{array}{l}-0.007 \\
(0.059)\end{array}$ & $\begin{array}{c}-0.076^{* * *} \\
(0.027)\end{array}$ \\
\hline Observations & 5983 & 7460 & 6960 & 6960 & 7460 & 7460 \\
\hline Treated & 291 & 294 & 283 & 283 & 294 & 294 \\
\hline Never treated & 449 & 452 & 413 & 413 & 452 & 452 \\
\hline Average dep var & 1.675 & 34.407 & 0.207 & 0.222 & 3.290 & 0.636 \\
\hline
\end{tabular}

Notes: This table presents the overall ATT following Callaway and Sant'Anna (2021) for the treatment of humanitarian demining during peace. Post demining is the weighted average of all group-time average treatment effects with weights proportional to group size. The outcomes were computed using a radius of $5 \mathrm{~km}$ around the demining. Panel $\mathrm{A}, \mathrm{B}$, and $\mathrm{C}$ present the results controlling with an indicator that takes the value one if there was a demining event within a buffer of 3,5 , and $7 \mathrm{Km}$ the year before the demining. In the case of the never treated the dummy takes the value if there was a demining event the year before within a buffer of $3 \mathrm{~km} / 5 \mathrm{~km} / 7 \mathrm{~km}$. We include the covariate following Sant'Anna and Zhao (2020) doubly robust method. We include the covariate following Sant'Anna and Zhao (2020) doubly robust method. Bootstrap standard errors clustered at the event level. * is significant at the $10 \%$ level, $* *$ is significant at the $5 \%$ level, $* * *$ is significant at the $1 \%$ level 
TABLE A17. Spillover effects of military demining: Covariates

\begin{tabular}{|c|c|c|c|c|c|c|}
\hline \multirow[b]{3}{*}{ Dep. variable: } & \multirow[t]{2}{*}{ (1) } & \multirow[t]{2}{*}{$(2)$} & $(3)$ & (4) & (5) & (6) \\
\hline & & & \multicolumn{2}{|c|}{ Test scores: } & & \\
\hline & $\begin{array}{l}\text { Nighttime } \\
\text { Lights }\end{array}$ & $\begin{array}{c}\text { Population } \\
\text { density }\end{array}$ & Math & Reading & $\begin{array}{c}\text { Forest } \\
\text { loss }\end{array}$ & Coca \\
\hline
\end{tabular}

Panel A: Buffer of $3 \mathrm{~km}$

Post demining

$\begin{array}{cccccc}0.015 & -0.614^{* * *} & 0.006 & -0.010 & 0.207^{* * *} & -0.118^{* * *} \\ (0.013) & (0.200) & (0.006) & (0.007) & (0.025) & (0.027)\end{array}$

Panel B: Buffer of $5 \mathrm{~km}$

Post demining
$0.028^{*}$
$-0.325^{*}$
$-0.015^{* *}$
$0.155^{* * *}$
$-0.111^{* * *}$
(0.015)
$(0.183)$
(0.006) (0.007)
(0.024)
$(0.029)$

Panel C: Buffer of $7 \mathrm{~km}$

\begin{tabular}{lcccccc} 
Post demining & $0.038^{* *}$ & -0.224 & 0.003 & -0.012 & $0.127^{* * *}$ & $-0.085^{* * *}$ \\
& $(0.015)$ & $(0.194)$ & $(0.007)$ & $(0.008)$ & $(0.026)$ & $(0.029)$ \\
Observations & 90504 & 100560 & 69340 & 69370 & 100560 & 100560 \\
Treated & 9630 & 9630 & 6641 & 6641 & 9630 & 9630 \\
Never treated & 426 & 426 & 293 & 296 & 426 & 426 \\
Average dep var & 0.973 & 33.381 & 0.149 & 0.168 & 3.721 & 2.392 \\
\hline
\end{tabular}

Notes: This table presents the overall ATT following Callaway and Sant'Anna (2021) for the treatment of military demining during peace. Post demining is the weighted average of all group-time average treatment effects with weights proportional to group size. The outcomes were computed using a radius of $5 \mathrm{~km}$ around the demining. Panel A, B, and $\mathrm{C}$ present the results controlling with an indicator that takes the value one if there was a demining event within a buffer of 3,5, and $7 \mathrm{Km}$ the year before the demining. In the case of the never treated the dummy takes the value if there was a demining event the year before within a buffer of $3 \mathrm{~km} / 5 \mathrm{~km} / 7 \mathrm{~km}$. We include the covariate following Sant'Anna and Zhao (2020) doubly robust method. Bootstrap standard errors clustered at the municipality level. * is significant at the $10 \%$ level, ${ }^{* *}$ is significant at the $5 \%$ level, ${ }^{* * *}$ is significant at the $1 \%$ level 
TABLE A18. Spillover effects of humanitarian demining: Excluding treated buffers

\begin{tabular}{|c|c|c|c|c|c|c|}
\hline & (1) & $(2)$ & $(3)$ & (4) & $(5)$ & (6) \\
\hline & & & \multicolumn{2}{|c|}{ Test scores: } & & \\
\hline Dep. variable: & $\begin{array}{c}\text { Nighttime } \\
\text { Lights }\end{array}$ & $\begin{array}{c}\text { Population } \\
\text { density }\end{array}$ & Math & Reading & $\begin{array}{c}\text { Forest } \\
\text { loss }\end{array}$ & Coca \\
\hline
\end{tabular}

Panel A: Buffer of $3 \mathrm{~km}$

Post demining

$\begin{array}{cccccc}0.098^{* *} & 0.699 & 0.054^{* *} & 0.058^{* *} & 0.062 & -0.129^{* * *} \\ (0.044) & (0.454) & (0.025) & (0.024) & (0.055) & (0.047)\end{array}$

Panel B: Buffer of $5 \mathrm{~km}$

Post demining

$\begin{array}{cccccc}0.127^{* * *} & 0.829 * & 0.063^{* *} & 0.072^{* * *} & 0.083 & -0.134^{* *} \\ (0.041) & (0.449) & (0.026) & (0.026) & (0.058) & (0.055)\end{array}$

Panel C: Buffer of $7 \mathrm{~km}$

\begin{tabular}{lcccccc} 
Post demining & $\begin{array}{c}0.133^{* * *} \\
(0.042)\end{array}$ & $\begin{array}{c}0.877^{*} \\
(0.521)\end{array}$ & $\begin{array}{c}0.079^{* * *} \\
(0.028)\end{array}$ & $\begin{array}{c}0.087^{* * *} \\
(0.026)\end{array}$ & $\begin{array}{c}0.068 \\
(0.065)\end{array}$ & $\begin{array}{c}-0.139^{* *} \\
(0.056)\end{array}$ \\
Observations (Panel A) & 5208 & 6600 & 6110 & 6110 & 6600 & 6600 \\
Observations (Panel B) & 5035 & 6390 & 5900 & 5900 & 6390 & 6390 \\
Observations (Panel C) & 4902 & 6210 & 5720 & 5720 & 6210 & 6210 \\
Treated (Panel A) & 205 & 208 & 198 & 198 & 208 & 208 \\
Treated (Panel B) & 184 & 187 & 177 & 177 & 187 & 187 \\
Treated (Panel C) & 166 & 169 & 159 & 159 & 169 & 169 \\
Never treated (Panel A) & 449 & 452 & 413 & 413 & 452 & 452 \\
Never treated (Panel B) & 449 & 452 & 413 & 413 & 452 & 452 \\
Never treated (Panel C) & 449 & 452 & 413 & 413 & 452 & 452 \\
Average dep var (Panel A) & 1.662 & 33.197 & 0.205 & 0.221 & 3.297 & 0.703 \\
Average dep var (Panel B) & 1.659 & 32.964 & 0.204 & 0.220 & 3.291 & 0.716 \\
Average dep var (Panel C) & 1.663 & 32.868 & 0.203 & 0.220 & 3.288 & 0.728 \\
\hline
\end{tabular}

Notes: This table presents the overall ATT following Callaway and Sant'Anna (2021) for the treatment of humanitarian demining. Post demining is the weighted average of all group-time average treatment effects with weights proportional to group size. The outcomes were computed using a radius of $5 \mathrm{~km}$ around the demining. Panel A, B, and $\mathrm{C}$ presents the results excluding from the sample treated buffers with at least one demining in the previous year of the event around $3 \mathrm{~km}, 5 \mathrm{~km}$, and $7 \mathrm{~km}$ to the demining, respectively. Bootstrap standard errors clustered at the municipality level. $*$ is significant at the $10 \%$ level, $* *$ is significant at the $5 \%$ level, $* * *$ is significant at the $1 \%$ level 
TABLE A19. Spillover effects of military demining: Excluding treated buffers

\begin{tabular}{|c|c|c|c|c|c|c|}
\hline \multirow[b]{3}{*}{ Dep. variable: } & \multirow[t]{2}{*}{ (1) } & \multirow[t]{2}{*}{ (2) } & $(3)$ & (4) & \multirow[t]{2}{*}{ (5) } & \multirow[t]{2}{*}{ (6) } \\
\hline & & & Tes & scores: & & \\
\hline & $\begin{array}{l}\text { Nighttime } \\
\text { Lights }\end{array}$ & $\begin{array}{c}\text { Population } \\
\text { density }\end{array}$ & Math & Reading & $\begin{array}{c}\text { Forest } \\
\text { loss }\end{array}$ & Coca \\
\hline
\end{tabular}

Panel A: Buffer of $3 \mathrm{~km}$

Post demining

$\begin{array}{cccccc}0.007 & -0.548^{* *} & 0.004 & -0.002 & 0.188^{* * *} & -0.076^{* *} \\ (0.015) & (0.272) & (0.009) & (0.009) & (0.028) & (0.032)\end{array}$

Panel B: Buffer of $5 \mathrm{~km}$

Post demining

$\begin{array}{llllll}-0.001 & -0.384 & 0.006 & 0.005 & 0.175^{* * *} & -0.050 \\ (0.019) & (0.282) & (0.010) & (0.011) & (0.032) & (0.032)\end{array}$

Panel C: Buffer of $7 \mathrm{~km}$

\begin{tabular}{lcccccc} 
Post demining & -0.007 & -0.328 & 0.009 & 0.011 & $0.197^{* * *}$ & -0.023 \\
& $(0.020)$ & $(0.319)$ & $(0.011)$ & $(0.012)$ & $(0.034)$ & $(0.037)$ \\
Observations (Panel A) & 53082 & 58980 & 39170 & 39170 & 58980 & 58980 \\
Observations (Panel B) & 43542 & 48380 & 32110 & 32090 & 48380 & 48380 \\
Observations (Panel C) & 38007 & 42230 & 27890 & 27860 & 42230 & 42230 \\
Treated (Panel A) & 5472 & 5472 & 3624 & 3621 & 5472 & 5472 \\
Treated (Panel B) & 4412 & 4412 & 2918 & 2913 & 4412 & 4412 \\
Treated (Panel C) & 3797 & 3797 & 2496 & 2490 & 3797 & 3797 \\
Never treated (Panel A) & 426 & 426 & 293 & 296 & 426 & 426 \\
Never treated (Panel B) & 426 & 426 & 293 & 296 & 426 & 426 \\
Never treated (Panel C) & 426 & 426 & 293 & 296 & 426 & 426 \\
Average dep var (Panel A) & 0.971 & 34.491 & 0.158 & 0.178 & 3.550 & 2.244 \\
Average dep var (Panel B) & 0.977 & 34.402 & 0.159 & 0.180 & 3.497 & 2.222 \\
Average dep var (Panel C) & 0.974 & 34.205 & 0.160 & 0.181 & 3.468 & 2.204 \\
\hline
\end{tabular}

Notes: This table presents the overall ATT following Callaway and Sant'Anna (2021) for the treatment of military demining. Post demining is the weighted average of all group-time average treatment effects with weights proportional to group size. The outcomes were computed using a radius of $5 \mathrm{~km}$ around the demining. Panel A, B, and C presents the results excluding from the sample treated buffers with at least one demining in the previous year of the event around $3 \mathrm{~km}, 5 \mathrm{~km}$, and $7 \mathrm{~km}$ to the demining, respectively. Bootstrap standard errors clustered at the municipality level. ${ }^{*}$ is significant at the $10 \%$ level, ${ }^{* *}$ is significant at the $5 \%$ level, $* * *$ is significant at the $1 \%$ level 
TABLE A20. Robustness to only using never treated as controls

\begin{tabular}{|c|c|c|c|c|c|c|}
\hline \multirow[b]{3}{*}{ Dep. variable: } & \multirow[t]{2}{*}{ (1) } & \multirow[t]{2}{*}{$(2)$} & \multirow{2}{*}{\multicolumn{2}{|c|}{$\begin{array}{l}(3) \\
\text { Test scores: }\end{array}$}} & \multirow{3}{*}{$\begin{array}{c}(5) \\
\text { Forest } \\
\text { loss }\end{array}$} & \multirow[b]{3}{*}{ Coca } \\
\hline & & & & & & \\
\hline & $\begin{array}{l}\text { Nighttime } \\
\text { Lights }\end{array}$ & $\begin{array}{c}\text { Population } \\
\text { density }\end{array}$ & Math & Reading & & \\
\hline \multicolumn{7}{|c|}{ Panel A: Humanitarian demining } \\
\hline Post demining & $\begin{array}{c}0.112^{* * *} \\
(0.035)\end{array}$ & $\begin{array}{c}0.924^{* *} \\
(0.367)\end{array}$ & $\begin{array}{c}0.064 * * * \\
(0.020)\end{array}$ & $\begin{array}{c}0.079^{* * * *} \\
(0.021)\end{array}$ & $\begin{array}{l}-0.043 \\
(0.054)\end{array}$ & $\begin{array}{c}-0.105^{* * *} \\
(0.036)\end{array}$ \\
\hline \multicolumn{7}{|c|}{ Panel B: Military demining } \\
\hline Post demining & $\begin{array}{c}0.004 \\
(0.018)\end{array}$ & $\begin{array}{c}-0.888^{* * *} \\
(0.340)\end{array}$ & $\begin{array}{c}0.003 \\
(0.009)\end{array}$ & $\begin{array}{l}-0.004 \\
(0.010)\end{array}$ & $\begin{array}{c}0.259^{* * *} \\
(0.031)\end{array}$ & $\begin{array}{c}-0.129^{* * *} \\
(0.038)\end{array}$ \\
\hline Observations (Panel A) & 5983 & 7460 & 6960 & 6960 & 7460 & 7460 \\
\hline Observations (Panel B) & 90504 & 100560 & 69340 & 69370 & 100560 & 100560 \\
\hline Treated (Panel A) & 291 & 294 & 283 & 283 & 294 & 294 \\
\hline Treated (Panel B) & 9630 & 9630 & 6641 & 6641 & 9630 & 9630 \\
\hline Never treated (Panel A) & 449 & 452 & 413 & 413 & 452 & 452 \\
\hline Never treated (Panel B) & 426 & 426 & 293 & 296 & 426 & 426 \\
\hline Average dep var (Panel A) & 1.675 & 34.407 & 0.207 & 0.222 & 3.290 & 0.636 \\
\hline Average dep var (Panel B) & 0.973 & 33.381 & 0.149 & 0.168 & 3.721 & 2.392 \\
\hline
\end{tabular}

Notes: This table presents the overall ATT following Callaway and Sant'Anna (2021). Panel A presents the results for humanitarian demining, while panel B for military demining. Post demining is the weighted average of all grouptime average treatment effects with weights proportional to group size. The set of controls include only the never treated. The outcomes were computed using a radius of $5 \mathrm{~km}$ around the demining. Bootstrap standard errors clustered at the municipality level. ${ }^{*}$ is significant at the $10 \%$ level, ${ }^{* *}$ is significant at the $5 \%$ level, $* * *$ is significant at the $1 \%$ level.

TABLE A21. Robustness to excluding never treated as controls

\begin{tabular}{|c|c|c|c|c|c|c|}
\hline \multirow[b]{3}{*}{ Dep. variable: } & \multirow[t]{2}{*}{ (1) } & \multirow[t]{2}{*}{ (2) } & \multirow{2}{*}{\multicolumn{2}{|c|}{$\begin{array}{l}(3) \\
\text { Test scores: }\end{array}$}} & \multirow{3}{*}{$\begin{array}{c}(5) \\
\text { Forest } \\
\text { loss }\end{array}$} & \multirow[b]{3}{*}{ Coca } \\
\hline & & & & & & \\
\hline & $\begin{array}{l}\text { Nighttime } \\
\text { Lights }\end{array}$ & $\begin{array}{c}\text { Population } \\
\text { density }\end{array}$ & Math & Reading & & \\
\hline \multicolumn{7}{|c|}{ Panel A: Humanitarian demining } \\
\hline Post demining & $\begin{array}{c}0.144^{* *} \\
(0.070)\end{array}$ & $\begin{array}{l}1.026 \\
(0.831)\end{array}$ & $\begin{array}{c}0.176^{* * *} \\
(0.043)\end{array}$ & $\begin{array}{c}0.211^{* * * *} \\
(0.040)\end{array}$ & $\begin{array}{c}0.271^{* *} \\
(0.137)\end{array}$ & $\begin{array}{c}-0.267^{* * *} \\
(0.091)\end{array}$ \\
\hline \multicolumn{7}{|c|}{ Panel B: Military demining } \\
\hline Post demining & $\begin{array}{c}0.014 \\
(0.015)\end{array}$ & $\begin{array}{c}-0.871^{* * *} \\
(0.226)\end{array}$ & $\begin{array}{l}0.012^{*} \\
(0.006)\end{array}$ & $\begin{array}{c}-0.008 \\
(0.007)\end{array}$ & $\begin{array}{c}0.174^{* * * *} \\
(0.023)\end{array}$ & $\begin{array}{l}-0.039 \\
(0.025)\end{array}$ \\
\hline Observations (Panel A) & 2424 & 2940 & 2830 & 2830 & 2940 & 2940 \\
\hline Observations (Panel B) & 86670 & 96300 & 66410 & 66410 & 96300 & 96300 \\
\hline Treated (Panel A) & 291 & 294 & 283 & 283 & 294 & 294 \\
\hline Treated (Panel B) & 9630 & 9630 & 6641 & 6641 & 9630 & 9630 \\
\hline Average dep var (Panel A) & 1.733 & 38.005 & 0.212 & 0.223 & 3.312 & 0.338 \\
\hline Average dep var (Panel B) & 0.981 & 33.375 & 0.150 & 0.169 & 3.708 & 2.299 \\
\hline
\end{tabular}

Notes: This table presents the overall ATT following Callaway and Sant'Anna (2021). Panel A presents the results for humanitarian demining, while panel B for military demining. Post demining is the weighted average of all grouptime average treatment effects with weights proportional to group size. The set of controls excludes the never treated. The outcomes were computed using a radius of $5 \mathrm{~km}$ around the demining. Bootstrap standard errors clustered at the municipality level. * is significant at the $10 \%$ level, $* *$ is significant at the $5 \%$ level, $* * *$ is significant at the $1 \%$ level. 
TABLE A22. Robustness to allow for one-year anticipation

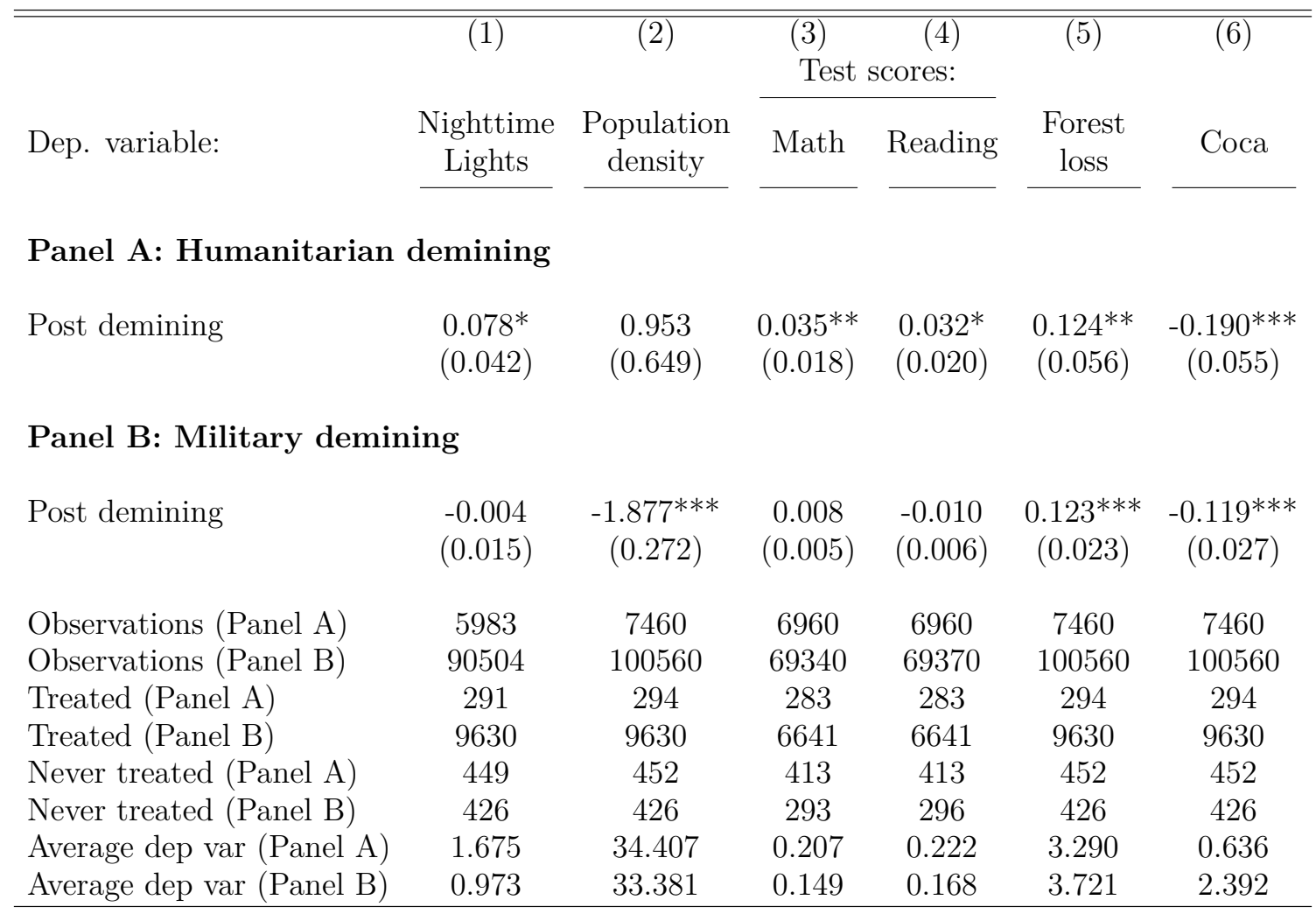

Notes: This table presents the overall ATT following Callaway and Sant'Anna (2021). We allow for an anticipation of the treatment of one-year. Panel A presents the results for humanitarian demining, while panel B for military demining. Post demining is the weighted average of all group-time average treatment effects with weights proportional to group size. The set of controls include not yet treated and never treated. The outcomes were computed using a radius of $5 \mathrm{~km}$ around the demining. Bootstrap standard errors clustered at the municipality level. * is significant at the $10 \%$ level, ${ }^{* *}$ is significant at the $5 \%$ level, *** is significant at the $1 \%$ level. 
TABle A23. Robustness to different radii: Humanitarian demining

\begin{tabular}{|c|c|c|c|c|c|c|}
\hline & (1) & $(2)$ & $(3)$ & (4) & $(5)$ & (6) \\
\hline & & & \multicolumn{2}{|c|}{ Test scores: } & & \\
\hline Dep. variable: & $\begin{array}{c}\text { Nighttime } \\
\text { Lights }\end{array}$ & $\begin{array}{c}\text { Population } \\
\text { density }\end{array}$ & Math & Reading & $\begin{array}{c}\text { Forest } \\
\text { loss }\end{array}$ & Coca \\
\hline
\end{tabular}

Panel A: $3 \mathrm{~km}$ radius

Post demining

$$
\begin{array}{cccccc}
0.143^{* * *} & 0.907^{* *} & 0.039 & 0.058^{* *} & 0.013 & -0.117^{* * *} \\
(0.053) & (0.442) & (0.026) & (0.023) & (0.057) & (0.027)
\end{array}
$$

Panel B: $4 \mathrm{~km}$ radius

Post demining

$$
\begin{array}{cccccc}
0.181^{* * *} & 0.910^{* *} & 0.081^{* * *} & 0.093^{* * *} & -0.021 & -0.118^{* * *} \\
(0.046) & (0.410) & (0.021) & (0.021) & (0.054) & (0.032)
\end{array}
$$

Panel C: $6 \mathrm{~km}$ radius

\begin{tabular}{|c|c|c|c|c|c|c|}
\hline Post demining & $\begin{array}{c}0.064^{* *} \\
(0.027)\end{array}$ & $\begin{array}{c}1.120 * * * \\
(0.352)\end{array}$ & $\begin{array}{c}0.076^{* * * *} \\
(0.020)\end{array}$ & $\begin{array}{c}0.091^{* * *} \\
(0.022)\end{array}$ & $\begin{array}{l}-0.035 \\
(0.044)\end{array}$ & $\begin{array}{c}-0.135^{* * *} \\
(0.041)\end{array}$ \\
\hline Observations & 5983 & 7460 & 6960 & 6960 & 7460 & 7460 \\
\hline Treated & 291 & 294 & 283 & 283 & 294 & 294 \\
\hline Never treated & 449 & 452 & 413 & 413 & 452 & 452 \\
\hline Average dep var (Panel A) & 1.829 & 32.578 & 0.137 & 0.147 & 2.249 & 0.415 \\
\hline Average dep var (Panel B) & 1.729 & 33.354 & 0.166 & 0.179 & 2.830 & 0.533 \\
\hline Average dep var (Panel C) & 1.630 & 35.842 & 0.211 & 0.229 & 3.684 & 0.727 \\
\hline Average dep var (Panel D) & 1.600 & 37.372 & 0.223 & 0.244 & 4.018 & 0.807 \\
\hline
\end{tabular}

Post demining

$$
\begin{array}{cccccc}
0.068^{* *} & 0.941^{* * *} & 0.101^{* * *} & 0.110^{* * *} & -0.023 & -0.122^{* * *} \\
(0.034) & (0.347) & (0.018) & (0.023) & (0.051) & (0.039)
\end{array}
$$

\section{Panel D: $7 \mathrm{~km}$ radius}

Notes: This table presents the overall ATT following Callaway and Sant'Anna (2021) for the treatment of humanitarian demining. Post demining is the weighted average of all group-time average treatment effects with weights proportional to group size. The set of controls include not yet treated and never treated. Panels A, B, C, and D present the results where dependent variable was computed using a radius of $3,4,6$, and $7 \mathrm{~km}$ around the event, respectively. Bootstrap standard errors clustered at the municipality level. * is significant at the $10 \%$ level, ** is significant at the $5 \%$ level, $* * *$ is significant at the $1 \%$ level. 
TABle A24. Robustness to different radii: Military demining

\begin{tabular}{|c|c|c|c|c|c|c|}
\hline \multirow{2}{*}{\multicolumn{2}{|c|}{$(1)$}} & $(2)$ & $(3)$ & $(4)$ & $(5)$ & $(6)$ \\
\hline & & & \multicolumn{2}{|c|}{ Test scores: } & & \\
\hline Dep. variable: & $\begin{array}{l}\text { Nighttime } \\
\text { Lights }\end{array}$ & $\begin{array}{c}\text { Population } \\
\text { density }\end{array}$ & Math & Reading & $\begin{array}{c}\text { Forest } \\
\text { loss }\end{array}$ & Coca \\
\hline
\end{tabular}

Panel A: $3 \mathrm{~km}$ radius

Post demining

$$
\begin{array}{cccccc}
0.019 & -1.193^{* * *} & -0.002 & -0.019^{* *} & 0.300^{* * *} & -0.134^{* * *} \\
(0.015) & (0.335) & (0.007) & (0.007) & (0.025) & (0.026)
\end{array}
$$

Panel B: $4 \mathrm{~km}$ radius

Post demining

$$
\begin{array}{cccccc}
0.014 & -1.021^{* * *} & -0.001 & -0.014^{* *} & 0.290^{* * *} & -0.108^{* * *} \\
(0.013) & (0.257) & (0.006) & (0.007) & (0.025) & (0.025)
\end{array}
$$

Panel C: $6 \mathrm{~km}$ radius

Post demining

$$
\begin{array}{cccccc}
0.003 & -0.945^{* * *} & -0.002 & -0.018^{* * *} & 0.246^{* * *} & -0.087^{* * *} \\
(0.012) & (0.196) & (0.006) & (0.006) & (0.023) & (0.026)
\end{array}
$$

\section{Panel D: $7 \mathrm{~km}$ radius}

Post demining

\begin{tabular}{cccccc}
-0.005 & $-0.947^{* * *}$ & 0.006 & -0.001 & $0.246^{* * *}$ & $-0.075^{* * *}$ \\
$(0.012)$ & $(0.193)$ & $(0.005)$ & $(0.006)$ & $(0.023)$ & $(0.025)$ \\
& & & & & \\
90504 & 100560 & 69340 & 69370 & 100560 & 100560 \\
9630 & 9630 & 6641 & 6641 & 9630 & 9630 \\
426 & 426 & 293 & 296 & 426 & 426 \\
0.958 & 37.058 & 0.069 & 0.078 & 2.670 & 1.828 \\
0.968 & 34.944 & 0.088 & 0.099 & 3.255 & 2.130 \\
0.974 & 32.171 & 0.116 & 0.131 & 4.103 & 2.625 \\
0.975 & 31.400 & 0.129 & 0.145 & 4.427 & 2.834 \\
\hline
\end{tabular}

Notes: This table presents the overall ATT following Callaway and Sant'Anna (2021) for the treatment of military demining. Post demining is the weighted average of all group-time average treatment effects with weights proportional to group size. The set of controls include not yet treated and never treated. Panels A, B, C, and D present the results where the dependent variable was computed using a radius of $3,4,6$, and $7 \mathrm{~km}$ around the event, respectively. Bootstrap standard errors clustered at the municipality level. * is significant at the $10 \%$ level, ${ }^{*} *$ is significant at the $5 \%$ level, $* * *$ is significant at the $1 \%$ level. 


\section{TABLE A25. Humanitarian demining and local activity excluding ETCR zones}

\begin{tabular}{|c|c|c|c|c|c|c|}
\hline \multirow{2}{*}{\multicolumn{2}{|c|}{$(1)$}} & $(2)$ & $(3)$ & $(4)$ & $(5)$ & (6) \\
\hline & & & \multicolumn{2}{|c|}{ Test scores: } & \multirow[b]{2}{*}{$\begin{array}{c}\text { Forest } \\
\text { loss }\end{array}$} & \multirow[b]{2}{*}{ Coca } \\
\hline Dep. variable: & $\begin{array}{l}\text { Nighttime } \\
\text { Lights }\end{array}$ & $\begin{array}{c}\text { Population } \\
\text { density }\end{array}$ & Math & Reading & & \\
\hline Post demining & $\begin{array}{c}0.117^{* * *} \\
(0.037)\end{array}$ & $\begin{array}{c}0.963^{* * *} \\
(0.357)\end{array}$ & $\begin{array}{c}0.067 * * * \\
(0.022)\end{array}$ & $\begin{array}{c}0.081^{* * *} \\
(0.021)\end{array}$ & $\begin{array}{l}-0.038 \\
(0.053)\end{array}$ & $\begin{array}{c}-0.111^{* * * *} \\
(0.035)\end{array}$ \\
\hline Observations & 5970 & 7440 & 6950 & 6950 & 7440 & 7440 \\
\hline Treated & 289 & 292 & 282 & 282 & 292 & 292 \\
\hline Never treated & 449 & 452 & 413 & 413 & 452 & 452 \\
\hline Average dep var & 1.672 & 34.273 & 0.207 & 0.222 & 3.290 & 0.633 \\
\hline
\end{tabular}

Notes: This table presents the overall ATT following Callaway and Sant'Anna (2021) for the treatments of humanitarian demining. Post demining is the weighted average of all group-time average treatment effects with weights proportional to group size. The set of controls include not yet treated and never treated. The outcomes were computed using a radius of $5 \mathrm{~km}$ around the demining. Those buffers that intersect a buffer of $1 \mathrm{~km}$ around the ETCR zones and demined after 2016, were removed from the sample. Bootstrap standard errors clustered at the event level. $*$ is significant at the $10 \%$ level, ${ }^{* *}$ is significant at the $5 \%$ level, $* * *$ is significant at the $1 \%$ level.

TABLE A26. Robustness to outliers

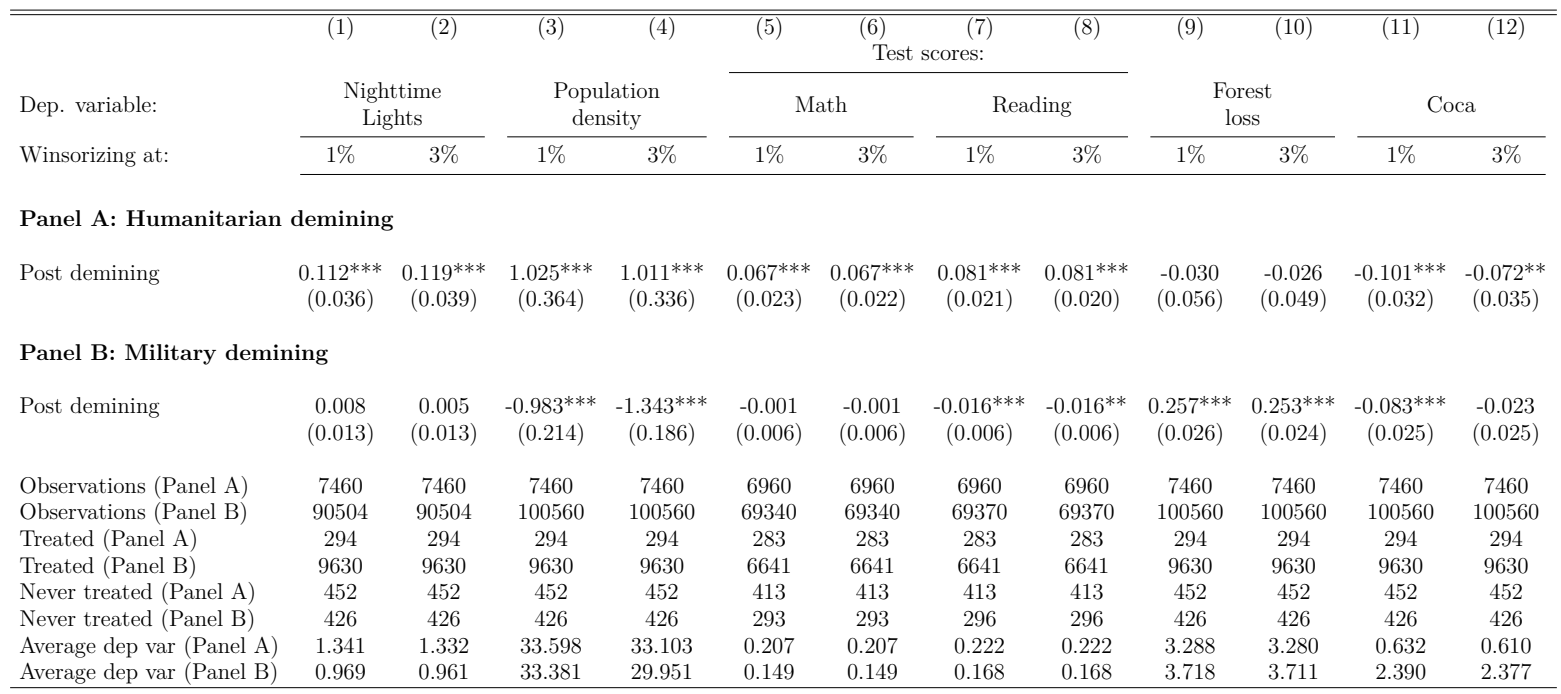

Notes: This table presents the overall ATT following Callaway and Sant'Anna (2021). Panel A presents the results for humanitarian demining, while panel B for military demining. Post demining is the weighted average of all group-time average treatment effects with weights proportional to group size. The set of controls include not yet treated and never treated. The outcomes were computed using a radius of $5 \mathrm{~km}$ around the demining. Odd columns present the results for the dependent variable winsorized at $1 \%$ and even columns at $3 \%$. Bootstrap standard errors clustered at the municipality level. ${ }^{*}$ is significant at the $10 \%$ level, $* *$ is significant at the $5 \%$ level, $* * *$ is significant at the $1 \%$ level. 


\section{A Additional Tables and Figures}

Figure B1. Change in conflict since peace-negotiation

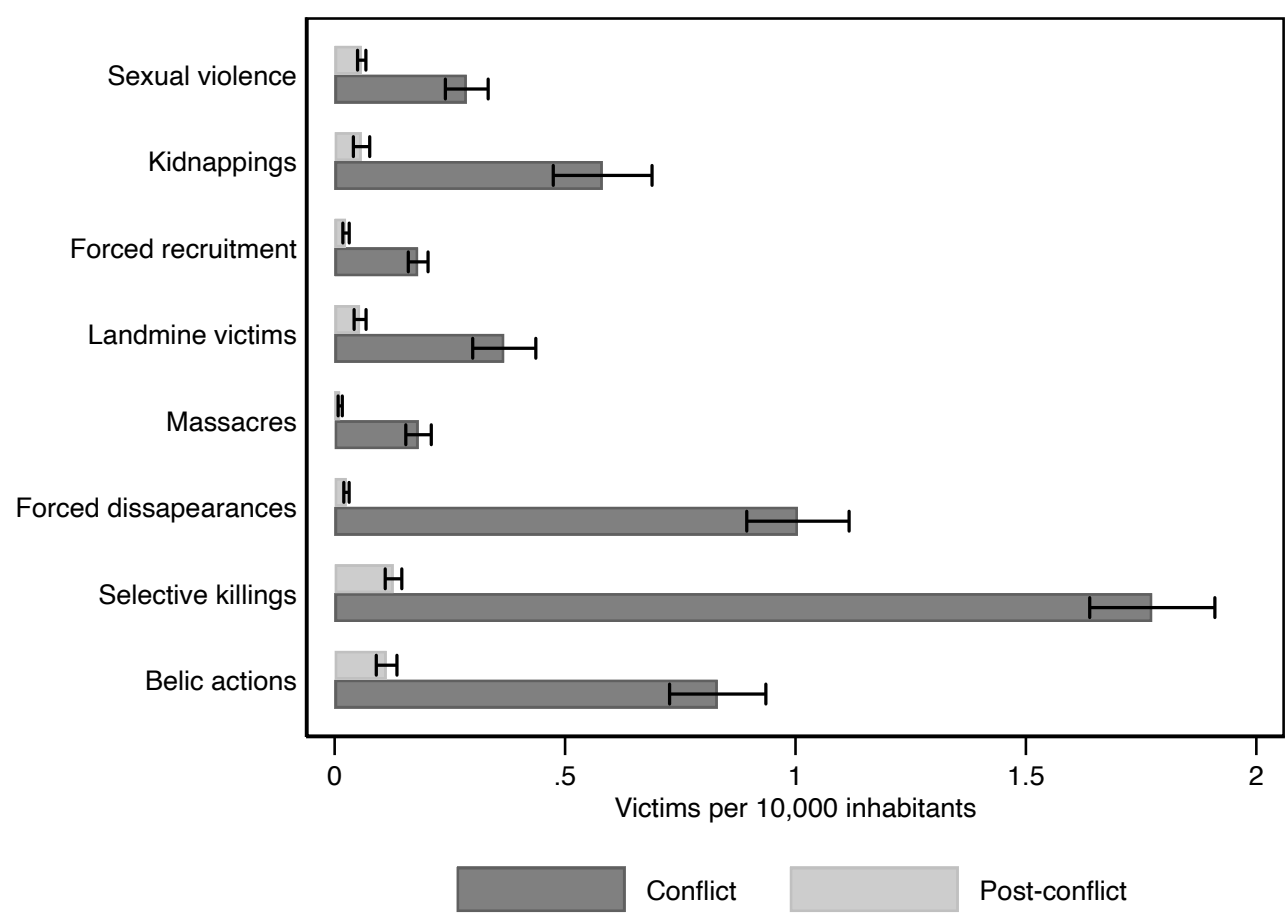

Notes: This figure presents the average incidence of conflict for different measures. We present the average across municipalities for the years between 2002 and 2012 (conflict) and between 2013 and 2019 (post-conflict). We present confidence intervals at the $95 \%$. 
Figure B2. Plan "Renacer" by FARC

Camaradas del Secretariado, Mi saludo

1. Impartante las relaciones del camarada TIMO. Con los amigos colaboradores del presidente CHAVEZ. Vale la pena darles a conocer el plan estratégico, asi como se le presento a su jefe, a su asesor y amigo CHACIN. igual de importante reforzar en los encuentros con los ELENOS propiciados por el gobierno, la necesidad de crear la fusión en algunas regiones de domino primordial de las FARC EP y buscar el apoyo de los asistentes a estas reuniones. A la senadora PIEDAD, hablarle sobre la necesidad de crear un partido del pueblo y buscar su alianza al movimiento Bolivariano.

2. Ya todos conocemos los cambios en la situación politica del país y al mismo tiempo la situación intema de nuestra organización guerrillera, por eso es tiempo de realizar algunos cambios temporales y pasar nuevamente a la táctica de GUERRA DE GUERRILLAS, pian propuesto como "RENACER REVOLUCIONARIO DE LAS MASAS" es alli donde se encuentra la estrategla y el exito de la gLerra de guerrillas con el desarrollo del PLAN PATRIOTA y i mal Ilamada POLITICA DE SEGURIDAD DEMOCRATICA, El enemigo recursos sociales tambín hemos visto afectado el espacio polloo camarada SANTFICH y MATIAS cOn las celuss del cauca, camarada SANTRICH y MATIAS con las células del cauca, Valle y Nariño, estructuras que dejaron fortalecidas antes de trasladarse al área dei Bloque Caribe. Por esto dentro del desarrolto de este plan propongo adelantar algunas actividades y otras ponerlas en consideración para su posterior ejecución.

3. Desarroilar por to menos, antes de terminar ef presente año, cursos de misiones especiales, programa desarrollado por el Comando Conjunto Central y que ha dado resultados positivos en corto tiempo luego de terminar el entrenamiento de las unidades.

4. Disponer de 5 á 6 millones de dólares del fondo del Secretariado, para adquirir intendencia, material de guerra $y$ comunleaciones. Necesario para fortalecer la capacidad de lucha de los guerrilleros urbanos y milicias. Del manejo de este dinero se encargara el Bioque Oriental y cada bloque aportara entre 1 y 2 millones según condiciones para este fint.

5. Aumentar los visos defensivos y de movilidad con minados para detener el avance de las operaciones enemigas, ya conocemos que las minas son el único factor que los detiene y los intimida, por esto aumentar los cursos de explosivistas para lograr un nivel de conocimiento en explosivos, generalizados dentro de la guertillerada e iniciar igualmente el entrenamiento del personal del MB y de milicias, haciendo énfasis en que no se debe de manipular los mismos con excesiva confianza los que lleva a accidentes.

6. El Comando Conjunto ya con capacidades en este ámbito, ejecutara algunas operaciones, para mantener el nombre de nuestra organización y evitar asi crear un ambiente de derrota progresiva a las FARC EP.

7. En la medida que se vayan ejecutando los entrenamientos, como ejercicios finales se deben de colocar objetivos reales, que propicien golpes al enemigo.

8. Con el uso de minas y explosivos se equilibran las cargas frente a un enemigo numeroso, bastante equipado y con gran poder de fuego.

9. Los resultados logrados en el Guayabero, son una muestra de la necesidad de entrenar bien militarmente a las milicias y miembros del MB, aun cuando se trata de un poder invaluable y necesario, solo se encuentran proporcionando inteligencia y logistica, situación que se dificulta cuando hay controles enemigos sabre las rutas a medios, ejemplo clato de esto es la situación presentada con Cesar. Hay que pensar en un mecanismo para reforzar a me mismo mecanismo sin exponer la seguridad y brindar más resutados al enemigo.

10. Es difficil para el enemigo mantener el despliegue de personał, material sobre un área permanente, por esto que al retomar la táctica de guerrillas móviles aunado con los golpes que pueden propinar las milicias y el MB. fortalecerá la presencia nuestra en áreas.

11. La táctica de francotiradores ya tratada desde la Octava Conferencia, se debe desarrollar con los recursas destinados dentro de la ejecución de este plan, adquirir el materiai necesario, fusiles y munición especializada por Bloque el efecto de la ejecución de esła maniobra tendrá iguales resultados que los minados.

12. Los grupos encargados de la tarea telefónica se debe incrementar en todas las áreas de operaciones enemigas, está comprobado que estando lo bastando cerca de ellos arroja buenos resultados para IC.

13. Alistar por bloque unidades de confianza y que tengan el servicio milltar para que se presenten como saldados profesionales y utilizarlos para IC. Como se esta trabajando en el Oriental y el Bloque Sur.

14. En la historia de las guerras de guerrillas, se ha demostrado que lo que ha creado un paralelo de regociación obligatorio entre la parte más fuerte y el apoyo aéreo, que termina por causar gran daño a la contraparte pero también es claro que si se logra golpear este paral, los resultados en la balanza se inclinan a favor, es por esto que se hace de extrema necesidad lograr la negociación de misiles que nos permitan propinar goipes contundentes al poderio aéreo del enemigo. Las tareas de destrucción de aeronaves mediante la Infitración como lo ha hecho el Oriental nos ha demostrado que el precio es alto se cometen errores.

Es todo y espero sus opiniones. Alfonso 
Figure B3. Number of demining events (2004-2019)

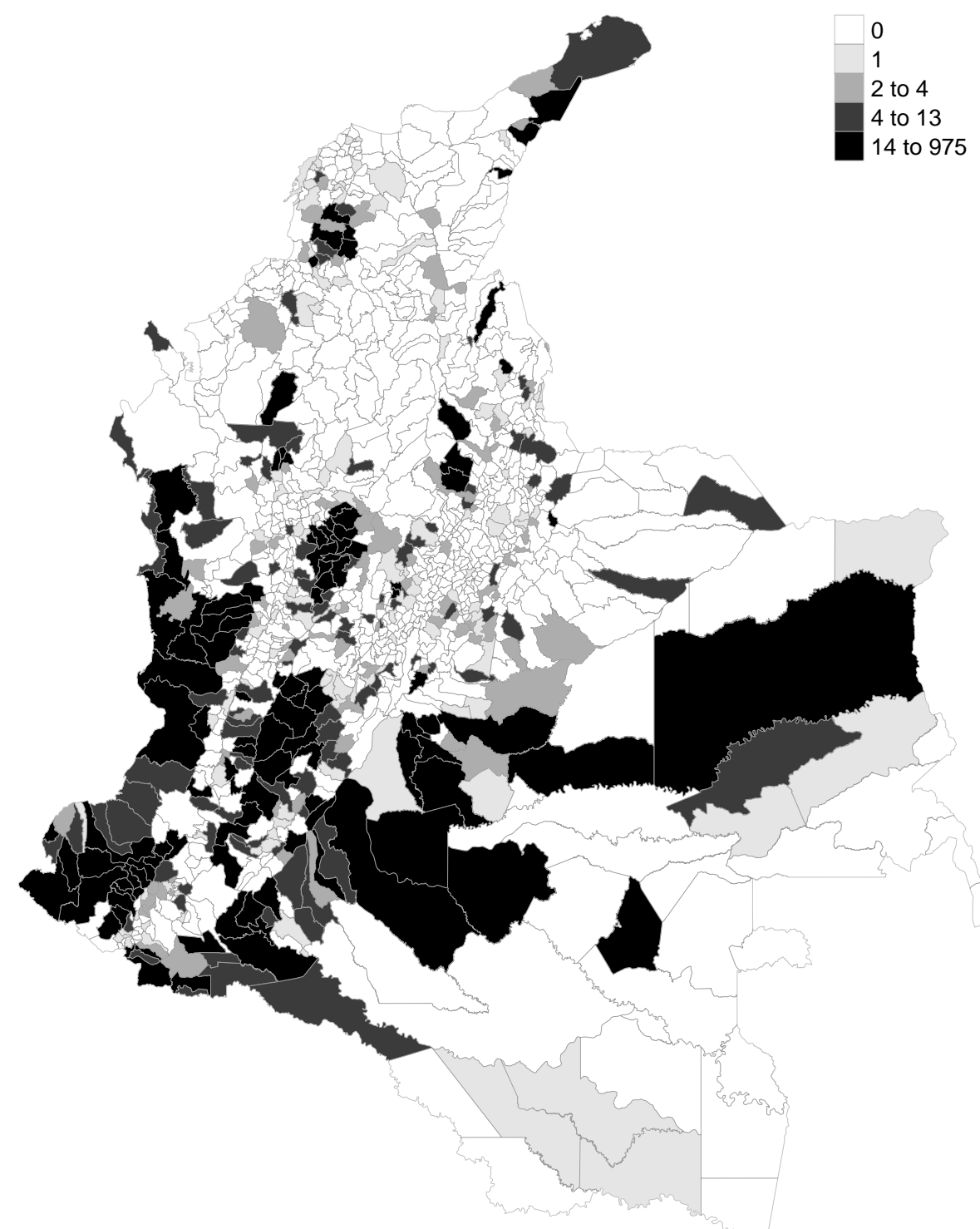

Notes: This map presents the spatial distribution of humanitarian and military demining events from 2004 to 2019. 
Figure B4. Grid-level differential characteristics by treatment status and timing of treatment

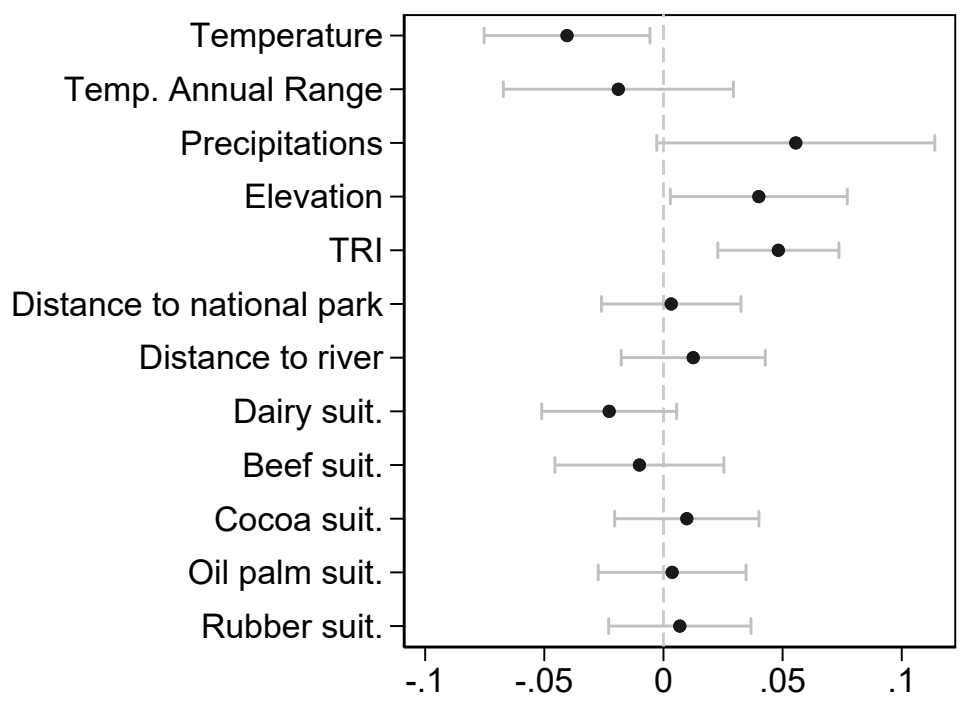

A. All: Treated versus non-treated

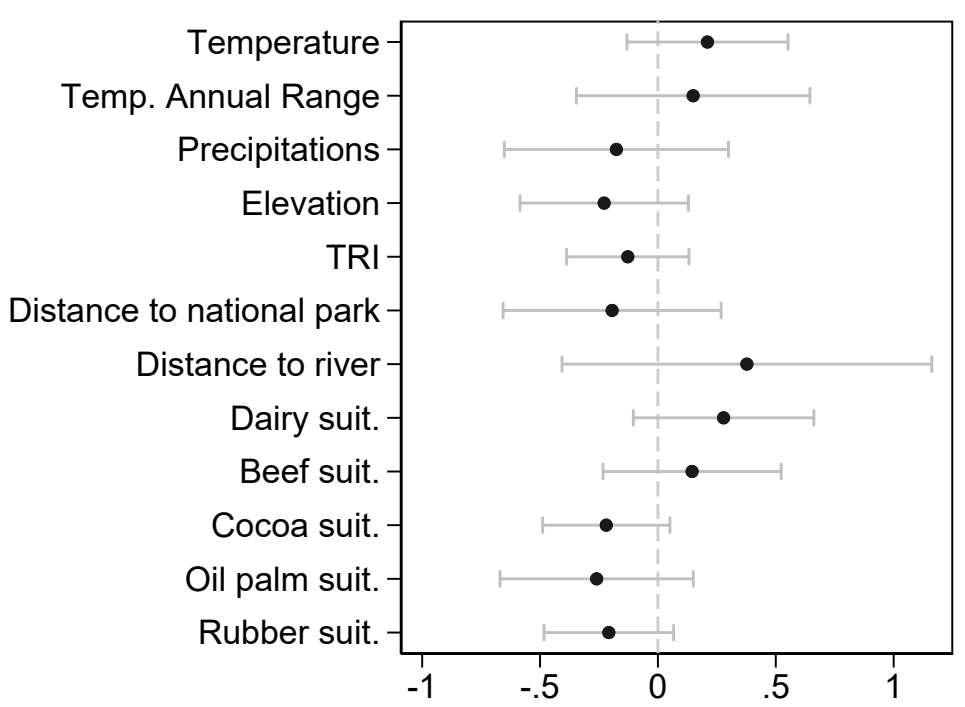

B. All: Timing of treatment

Notes: This figure presents the standardized differences by treatment status and treatment timing. In Panel A, we compare grids of $10 \times 10 \mathrm{~km}$ that were demined during 2004-2019 versus grids that were not demined within the same municipality. In Panel B, we compare within demined grids and look at the year of the first demining event. All characteristics are computed at the $10 \times 10 \mathrm{~km}$ grid. 
FIGURE B5. Humanitarian demining and local activity: Borusyak et al. (2021)

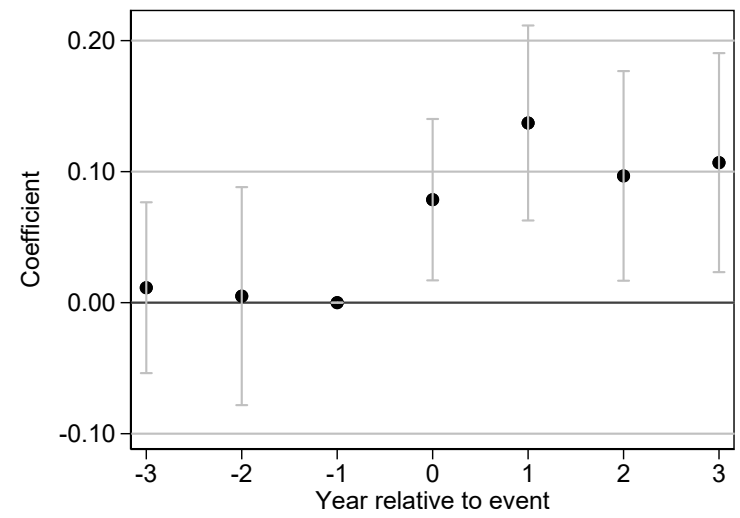

A. Nighttime lights

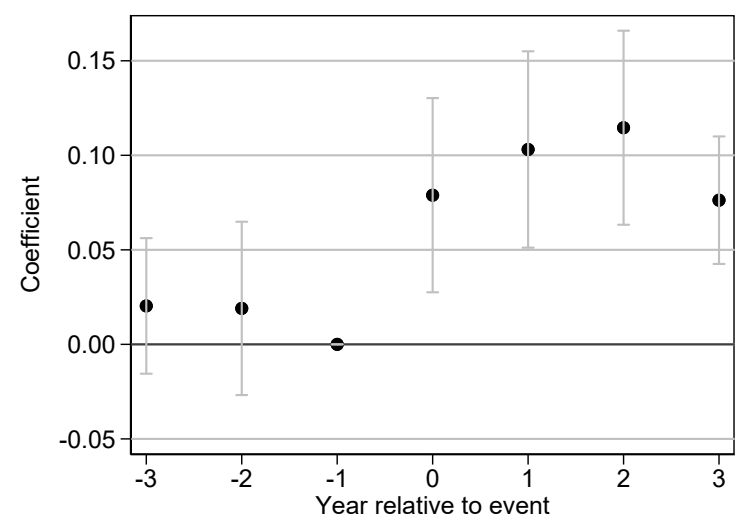

C. Test scores: Math

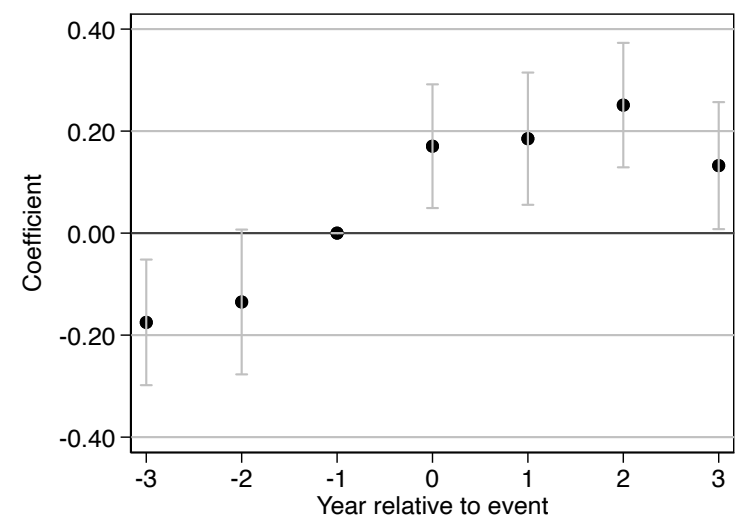

E. Forest loss

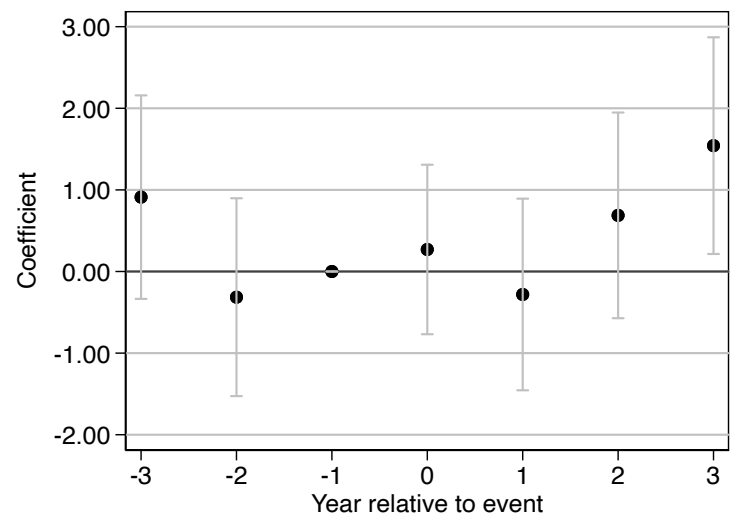

B. Population Density

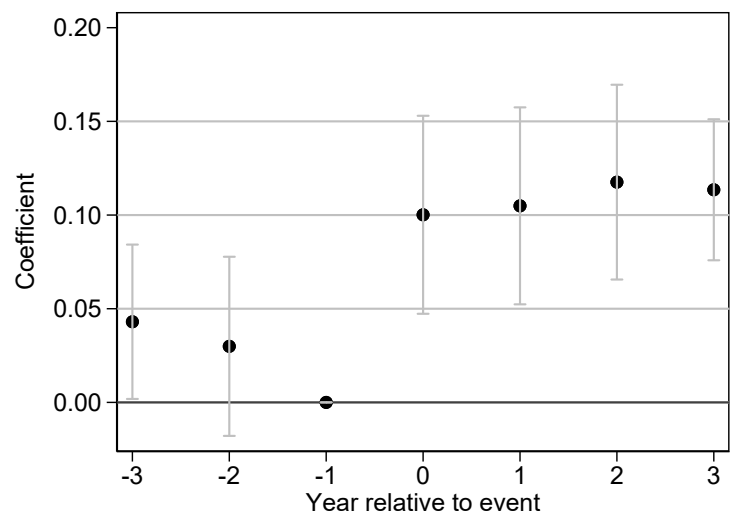

D. Test scores: Reading

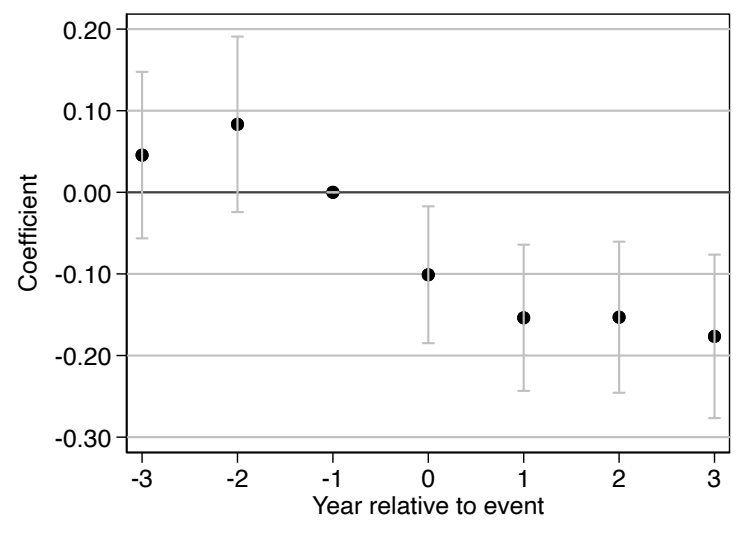

F. Coca

Notes: This figure presents the event study coefficients following Borusyak et al. (2021) for the treatment of humanitarian demining. We present the point estimates as well as the $95 \%$ confidence interval. Standard errors clustered at the event level. The outcomes were computed using a radius of $5 \mathrm{~km}$ around the demining. 
Figure B6. Military demining and local activity: Borusyak et al. (2021)

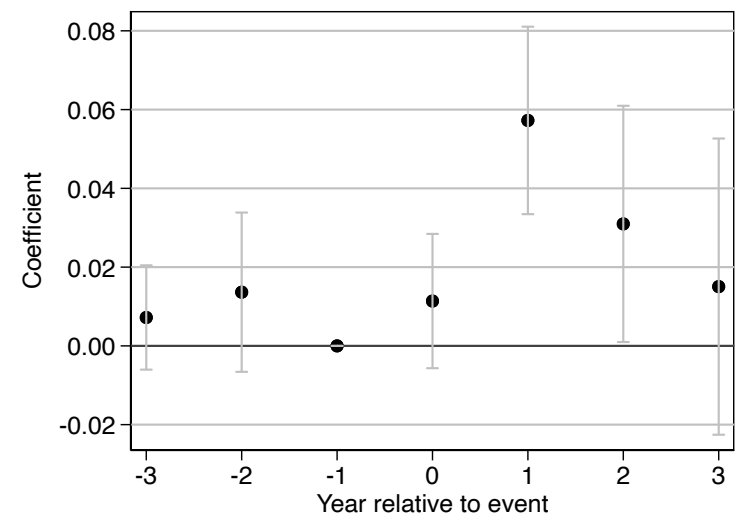

A. Nighttime lights

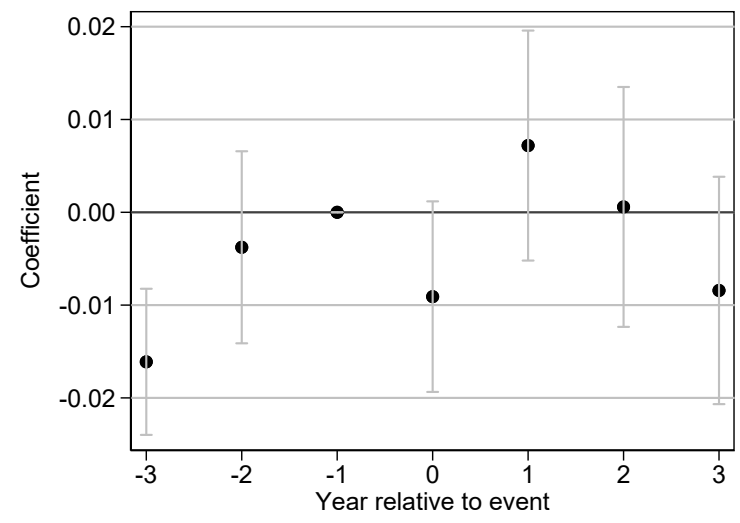

C. Test scores: Math

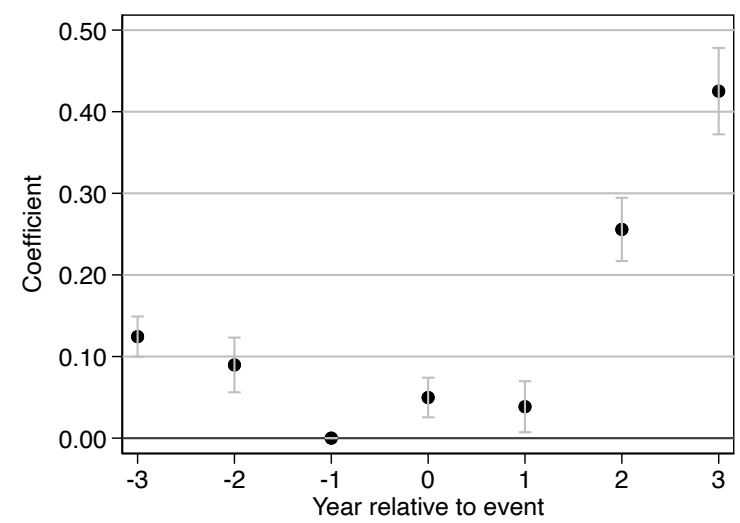

E. Forest loss

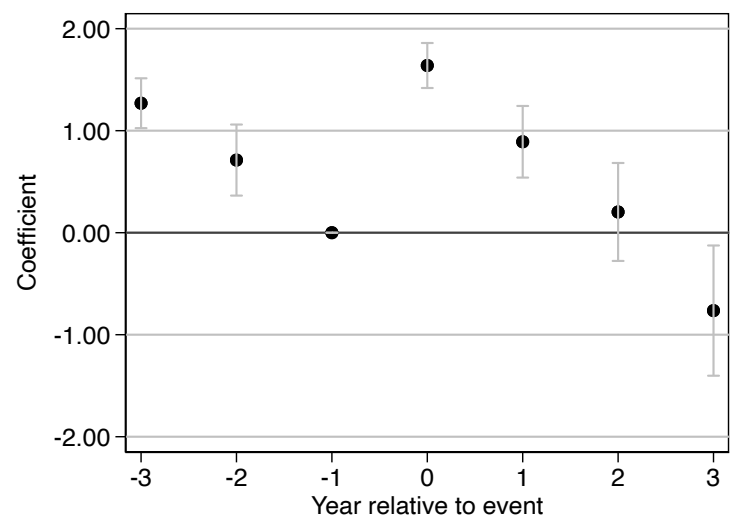

B. Population Density

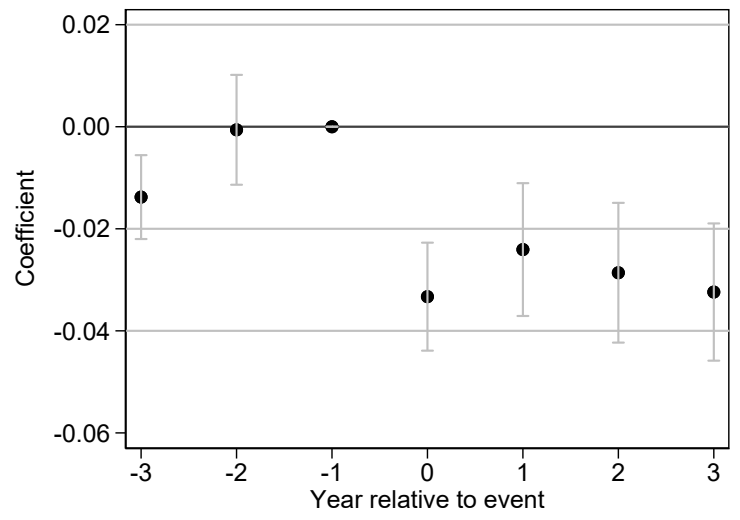

D. Test scores: Reading

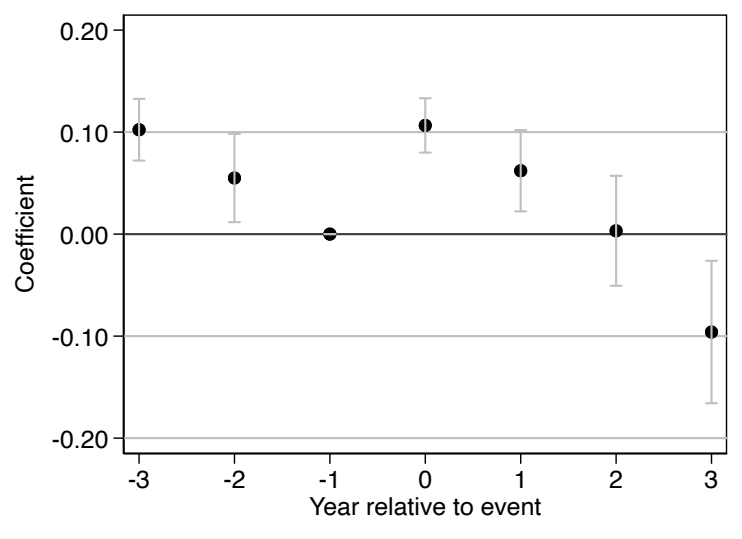

F. Coca

Notes: This figure presents the event study coefficients following Borusyak et al. (2021) for the treatment of military demining. We present the point estimates as well as the $95 \%$ confidence interval. Standard errors clustered at the event level. The outcomes were computed using a radius of $5 \mathrm{~km}$ around the demining. 
Figure B7. Humanitarian demining and local activity: De Chaisemartin and d'Haultfoeuille (2020)

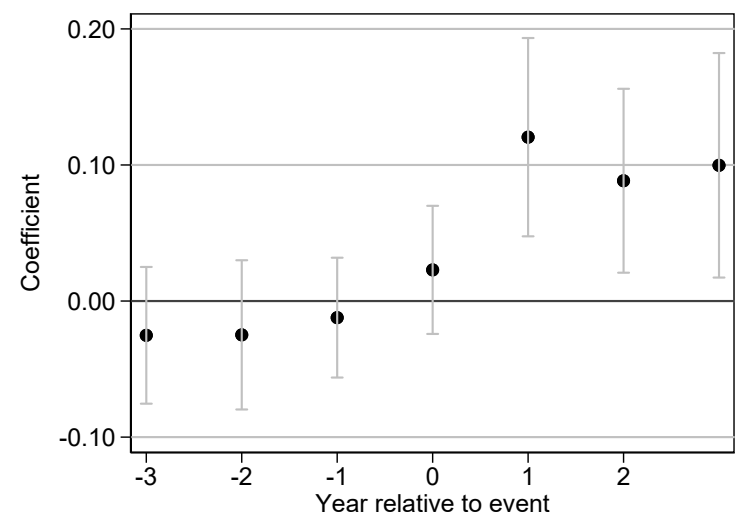

A. Nighttime lights

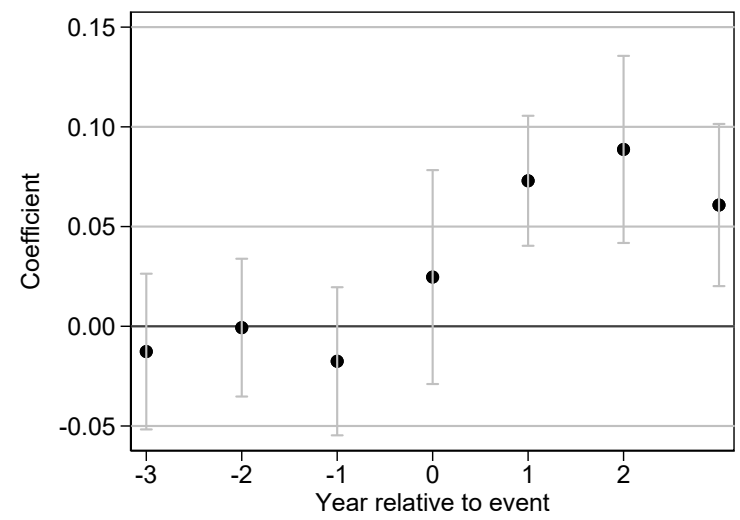

C. Test scores: Math

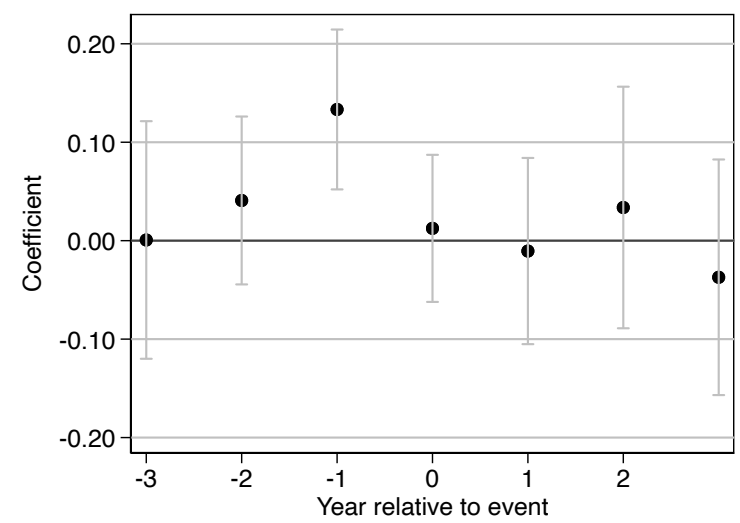

E. Forest loss

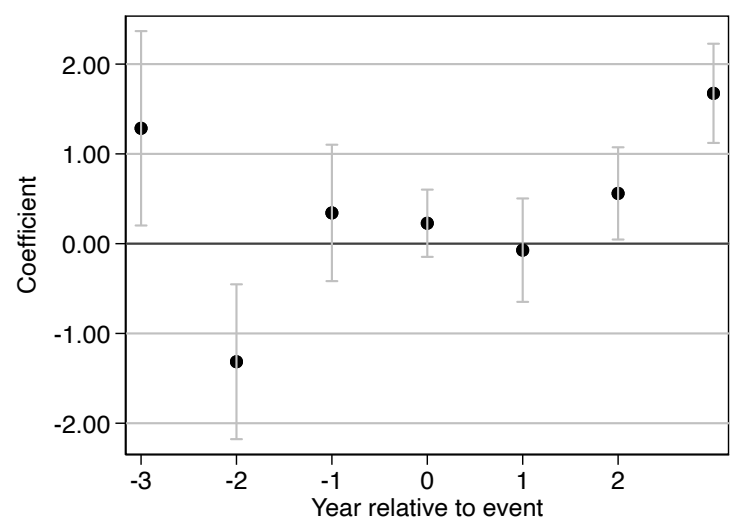

B. Population Density

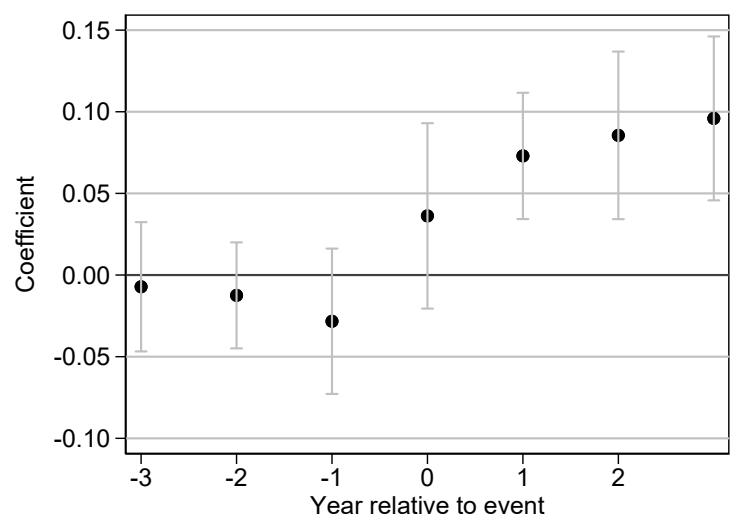

D. Test scores: Reading

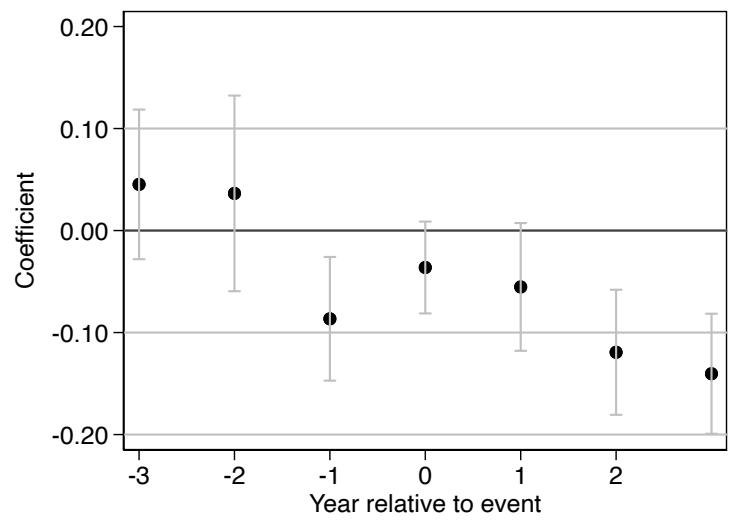

F. Coca

Notes: This figure presents the event study coefficients following De Chaisemartin and d'Haultfoeuille (2020) for the treatment of humanitarian demining. We present the point estimates as well as the $95 \%$ confidence interval. Standard errors clustered at the event level. The outcomes were computed using a radius of $5 \mathrm{~km}$ around the demining. 
Figure B8. Military demining and local activity: De Chaisemartin and d'Haultfoeuille (2020)

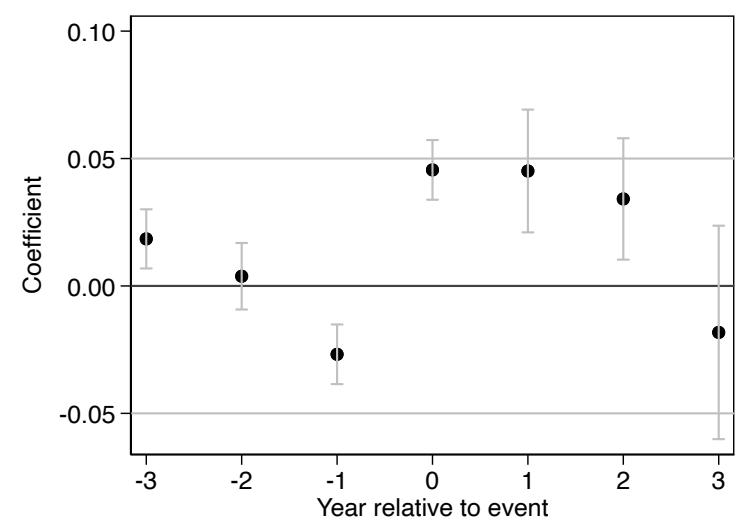

A. Nighttime lights

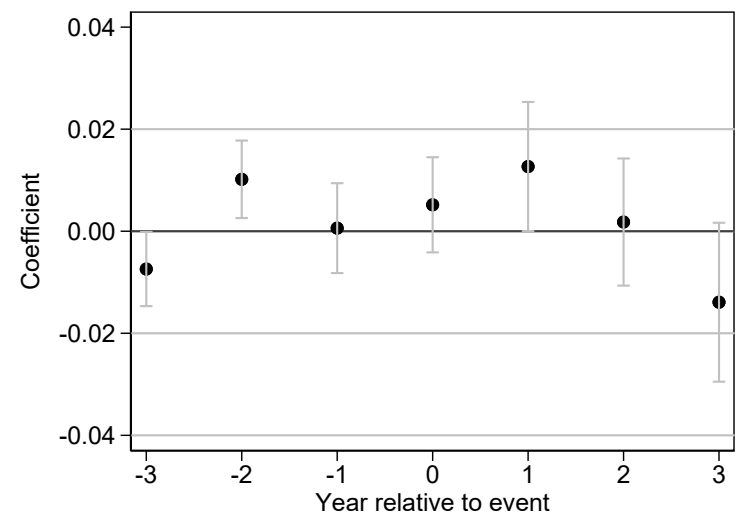

C. Test Scores: Math

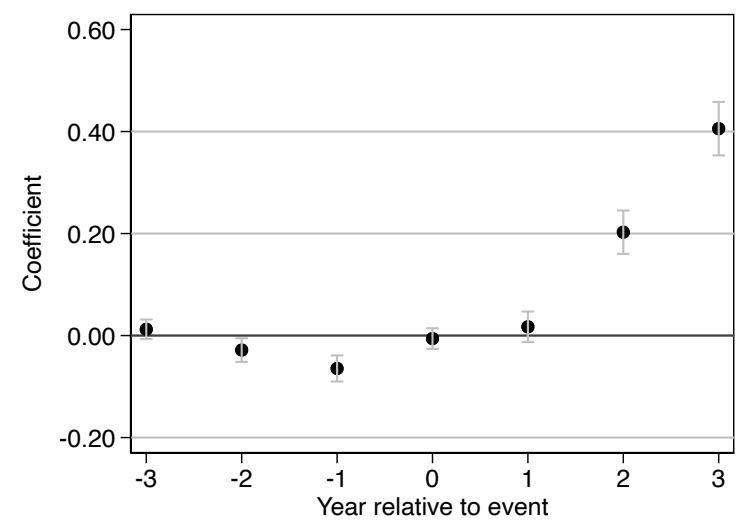

E. Forest loss

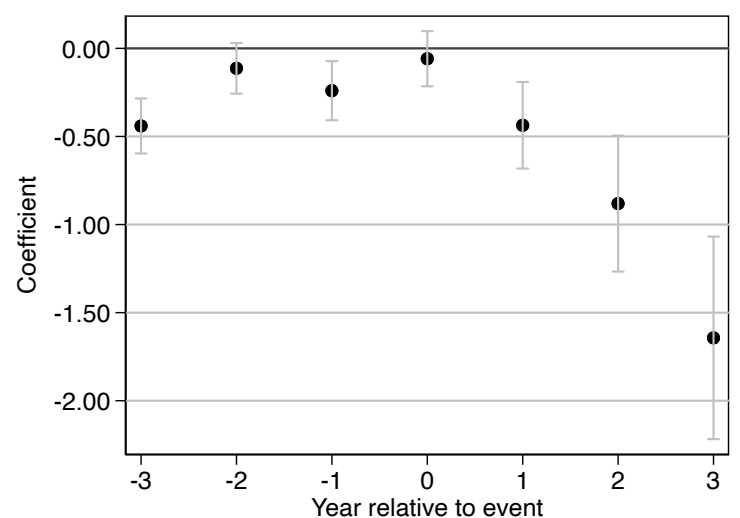

B. Population Density

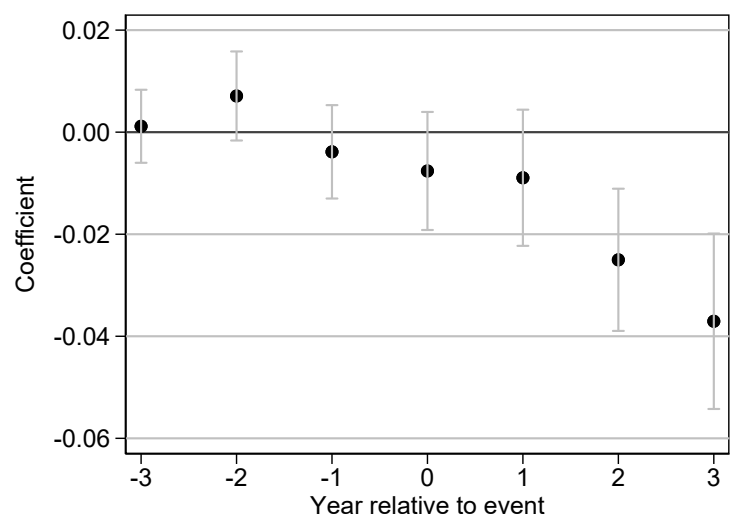

D. Ratio Approved Reading

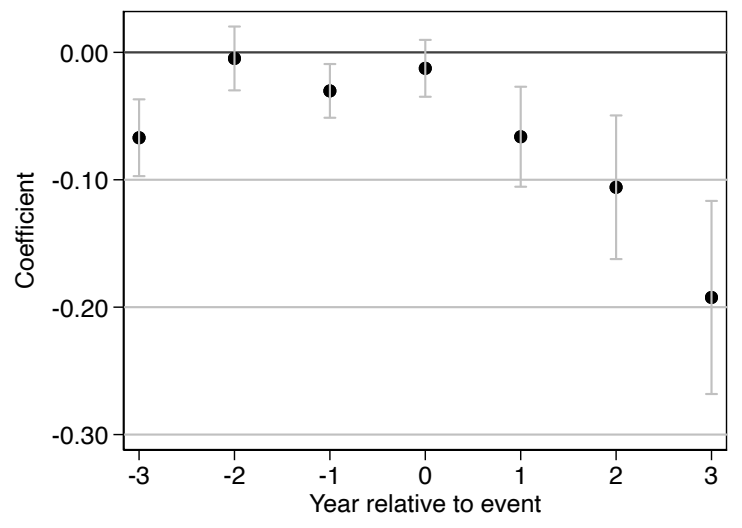

F. Coca

Notes: This figure presents the event study coefficients following De Chaisemartin and d'Haultfoeuille (2020) for the treatment of military demining. We present the point estimates as well as the $95 \%$ confidence interval. Standard errors clustered at the event level. The outcomes were computed using a radius of $5 \mathrm{~km}$ around the demining. 


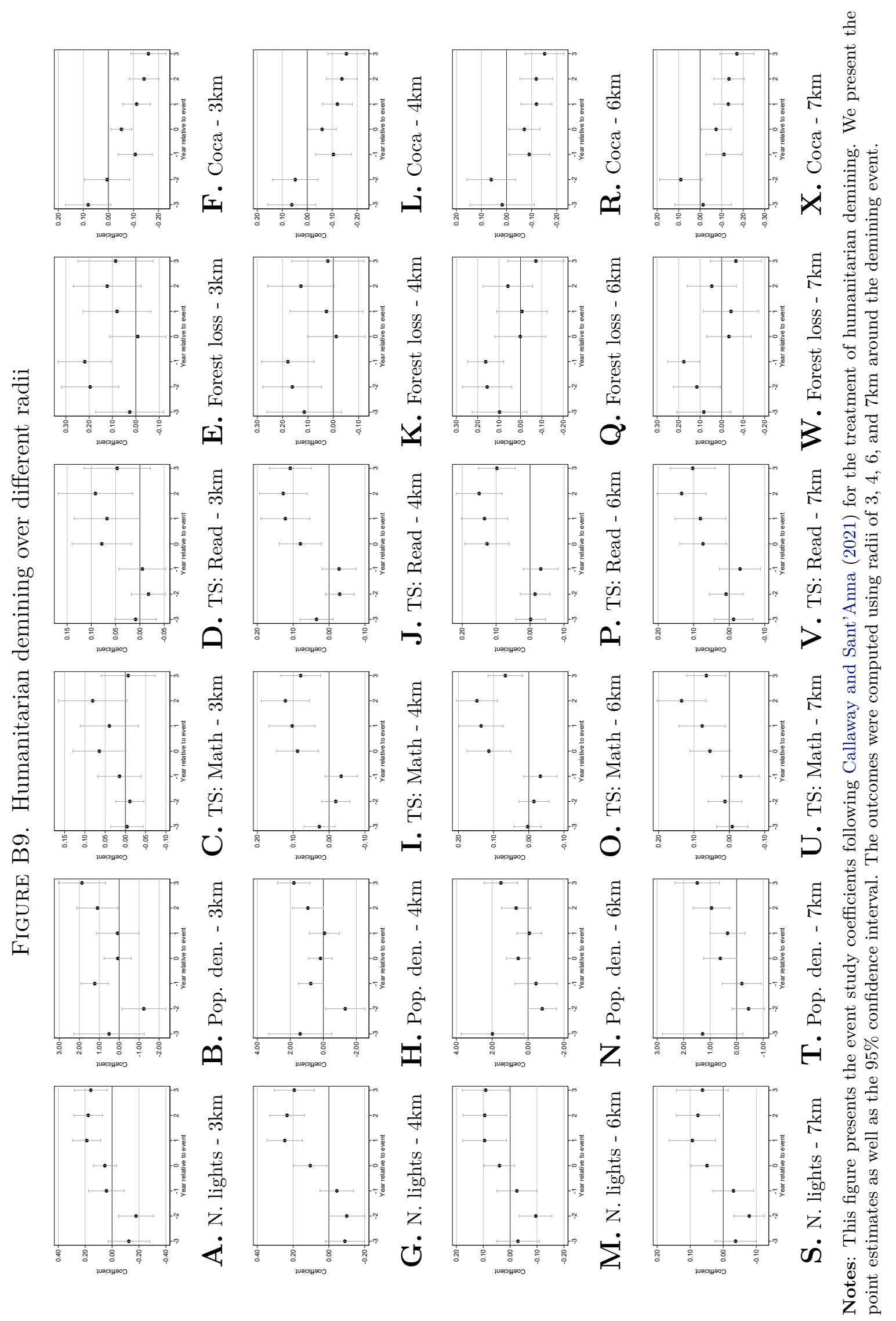




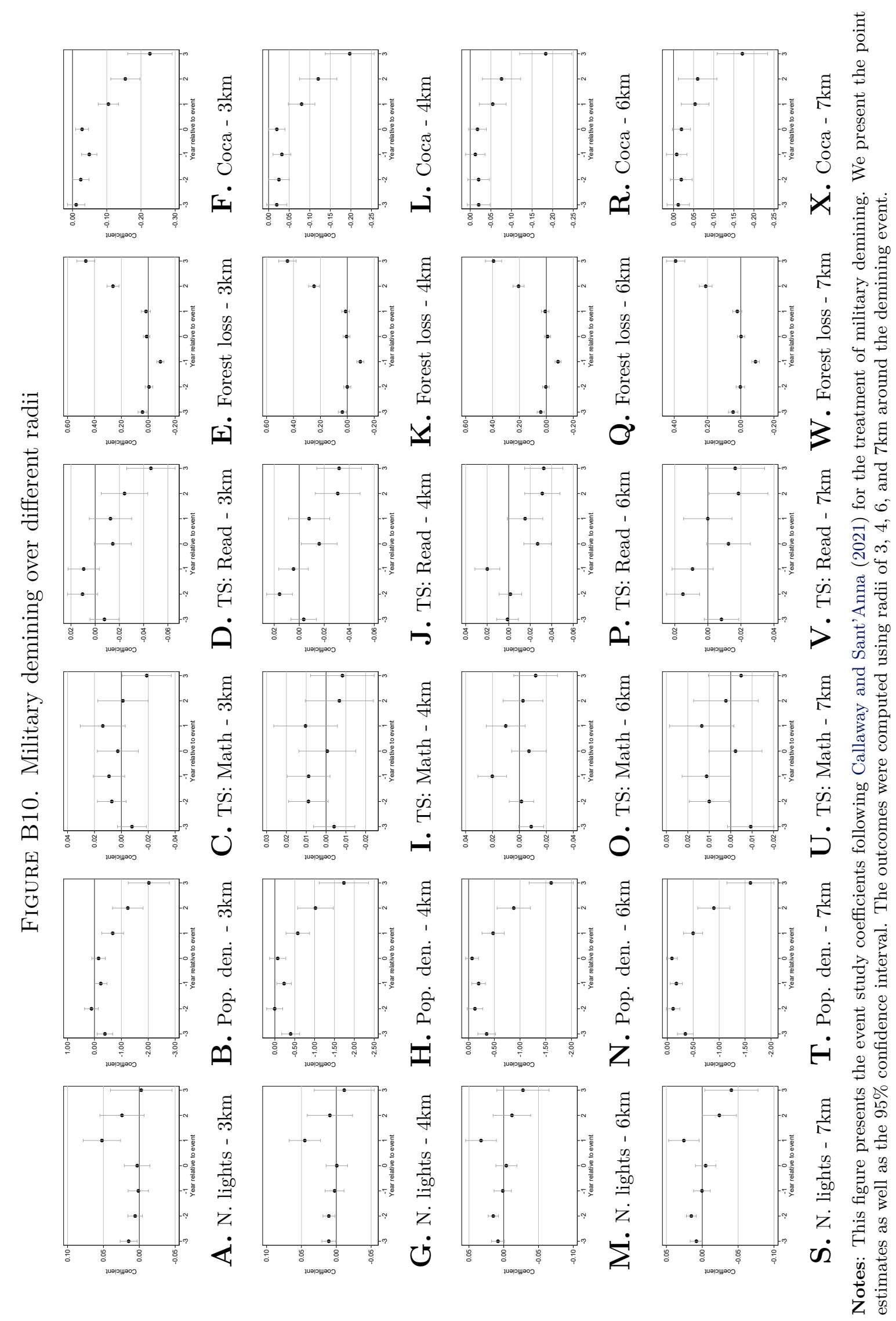


TABLE B1. Electricity subscribers and nighttime lights

\begin{tabular}{|c|c|c|}
\hline Dep. variable: & $\begin{array}{c}\text { (1) } \\
\text { Electricity subscribers } \\
\text { per capita }\end{array}$ & $\begin{array}{l}(2) \\
\text { Nighttime } \\
\text { lights }\end{array}$ \\
\hline Humanitarian demining $\times$ Post & $\begin{array}{c}0.005 \\
(0.005)\end{array}$ & \\
\hline Electricity subscribers per capita & & $\begin{array}{c}1.293^{* * *} \\
(0.232)\end{array}$ \\
\hline Observations & 10,244 & 9,220 \\
\hline R-squared & 0.938 & 0.677 \\
\hline Municipality FE & Yes & No \\
\hline Department-Year FE & Yes & Yes \\
\hline Baseline controls & Yes & Yes \\
\hline
\end{tabular}

Notes: This table presents the effect of humanitarian demining on electricity subscribers, as well as the relationship between electricity subscribers and nighttime lights. Humanitarian demining is a dummy that takes the value one for municipalities where humanitarian demining took place. Post is a dummy that takes the value one from 2013 onward. Electricity subscribers per capita is the number of electricity subscribers per inhabitant. The source of these data is the Information System of Utilities (SUI from its Spanish acronym). Nighttime lights is the hyperbolic sine transformation of the average nighttime luminosity. Standard errors clustered at the municipality level. * is significant at the $10 \%$ level, ** is significant at the $5 \%$ level, *** is significant at the $1 \%$ level. 
TABlE B2. Humanitarian demining and aid from international community

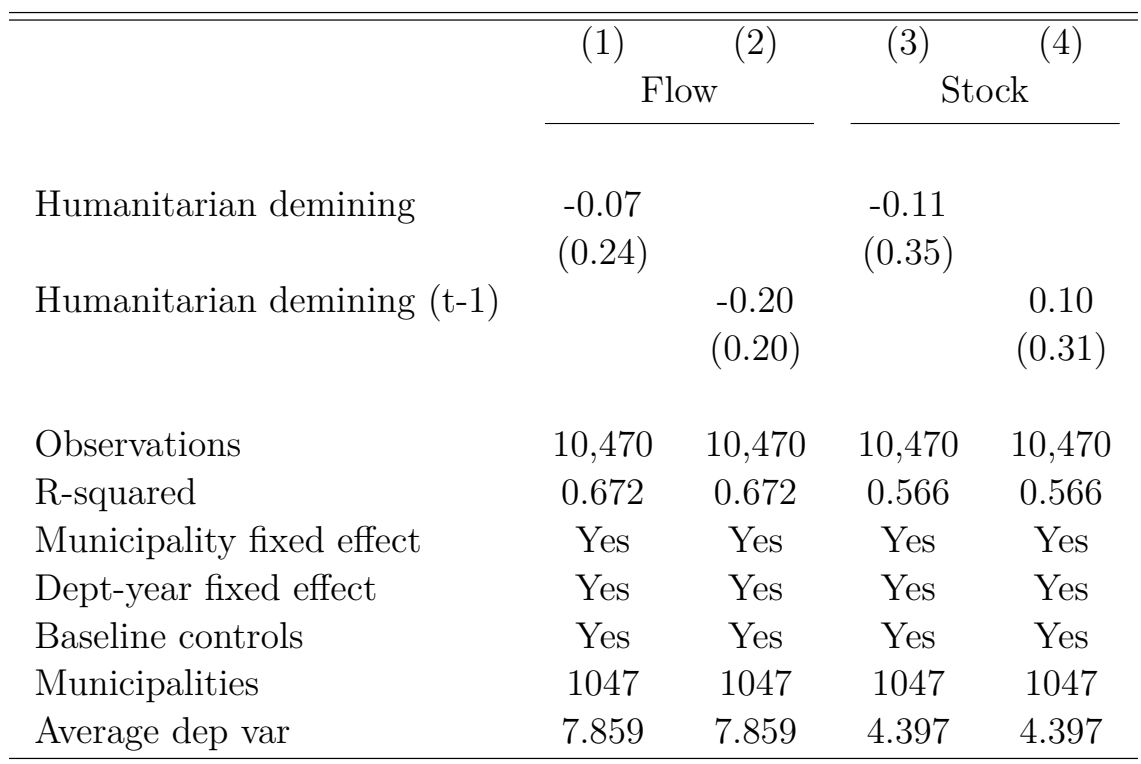

Notes: This table presents the relationship between humanitarian demining and aid from the international community at the municipality level. All the dependent variables are measured using the hyperbolic sine transformation. Flow is the flow of money received from aid in a given year, while stock is the total money signed in that year for aid-related reasons. Humanitarian demining is the total number of landmines demined by humanitarian organizations transformed using the hyperbolic sine transformation. All the regressions include the set of covariates: the total population, $\log$ distance to the capital, a rurality index, and a poverty index all measured in 2003 and interacted with year fixed effects. Robust standard errors are clustered at the municipality level. * is significant at the $10 \%$ level, $* *$ is significant at the $5 \%$ level, $* * *$ is significant at the $1 \%$ level. 